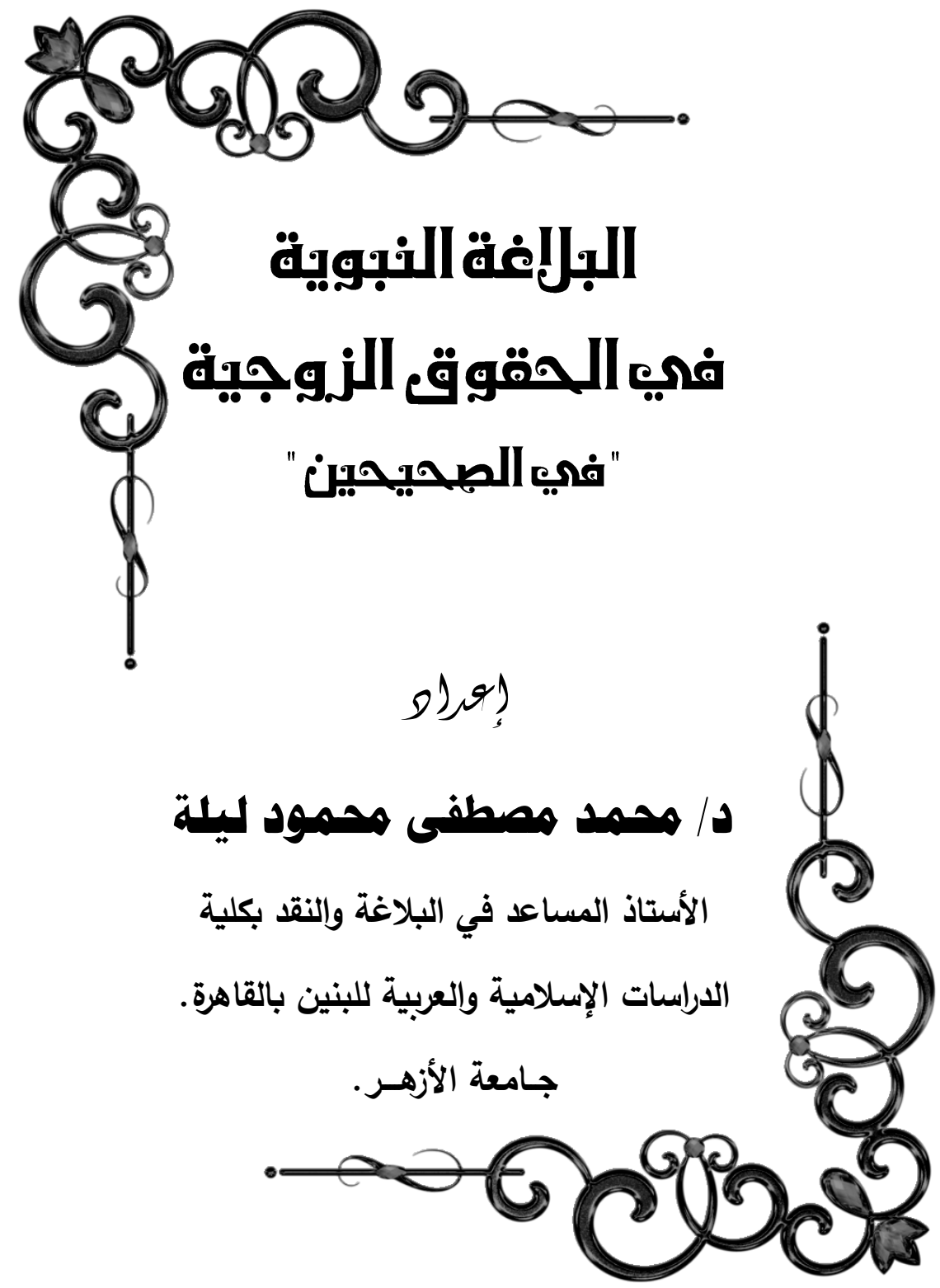




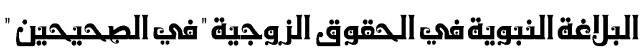

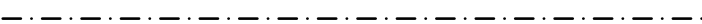




\section{هذه بحث:}

\section{الجلإفة النبوية فيه الحقوق الزوجية" فهي الصحيحين"}

\section{د/ محمد مصطفى محمود ليلة}

الأستاذ المساعد في البلاغة والنقد بكلية

الدراسات الإسلامية والعربية للبنين بالقاهرة.

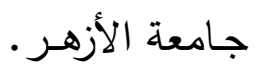

يتــاول هذا البحث سـمات البلاغـة النبويـة في الحقوق الزوجيـة مـن خـلال

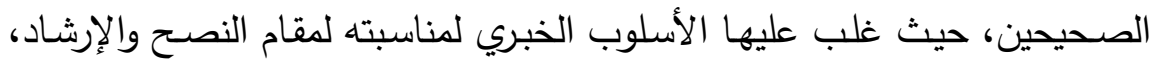
وجاءت موجزة قوية السبك مصيبة المعنى، مؤكدة بطرق متعددة، وكان لذلك عظيم الأثر في التأكيد على حقوق كل من الزوجين مما ساعد على سرعة الالتزام بها والعمل بمقتضاها، وجاءت الوصية بالمرأة بطرق مختلفة، راعى فيها البيان النبوي

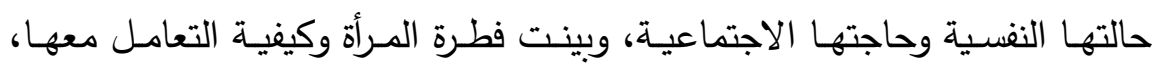
وأناطت بها مسؤولية البيت والعمل التربوي الكبير ، وجـاء الحوار هادئًاً واضــاً مـوجزاً متدرجاً جاذبـاً الانتبـاه لبيـان الحقوق الزوجيـة أو قضـية اجتماعيـة، وكـان

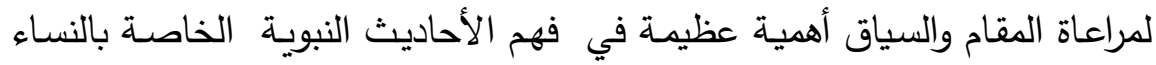

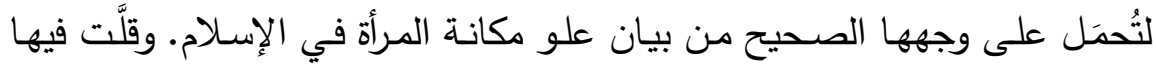

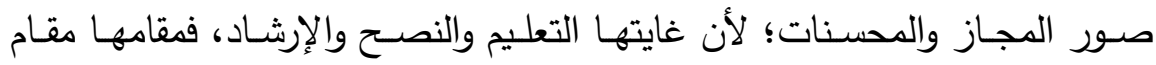
عظة وعبرة، ولا يحتاج إلى تحسين الكلام بقدر ما يحتاج إلى التأكيد على المعنى المراد. وجاءت الكناية عن الحقوق الزوجية متأثرة بالكنايات في القرآن الكريم في أسلوبها وطريقتها ومقامها، وألفاظها وحسن تصويرها وقوة تأثيرها، فجاءت بألفاظ

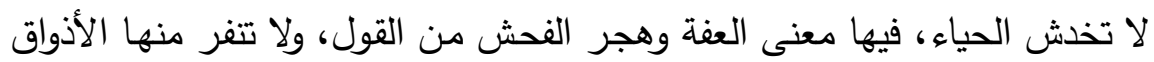




\section{البلاغة النبوية فهي الحقوق الزوجية" فهيء الصحيحين" \\ Summary \\ Prophetic rhetoric on marital rights "in the correct ones" \\ Dr. Mohammed Mustafa Mahmoud Laila \\ Assistant Professor of Rhetoric and \\ Criticism at the Faculty Islamic and Arabic \\ Studies for Boys in Cairo. The mosque.}

This study deals with the characteristics of the prophetic rhetoric in marital rights through the correct ones, where it is dominated by the experiential style of the occasion for advice and guidance. A concise summary is strong in casting down the misfortune of meaning, confirming in many ways. This has a great effect on asserting the rights of both spouses, And the duty came under it, and the commandment came to women in different ways, taking into account the statement of the Prophet's psychological condition and social need, and showed the nature of women and how to deal with them, and entrusted with the responsibility of the house and the work of education and the large dialogue came calm and clear summary gradually attracted attention to the statement of rights Marital or social issue, and to take into account the context and context of great importance in understanding the prophetic traditions of women to bear the correct face of the high status of women in Islam. And I said the images of metaphor and optimizers; because the purpose of education and counseling and guidance, the place of the place of greatness and lesson, does not need to improve speech as much as it needs to emphasize the meaning intended. The conjugal conjugal rights were influenced by the structures in the Holy Quran in their style, style, structure, words, good portrayal and force of influence, and came with words that do not scratch shyness, meaning the chastity and abandonment of obscene words, and do not alienate them from sound tastes.

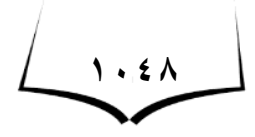




\section{الإسقدمهــة}

الحمد لله رب العالمين، أنزل على عبده الفرقان ليكون للعالمين نذيراً إلى يوم الدين، والصـلاة والسـلام على النبي الأمين، إمـام المرسلين، وخاتم

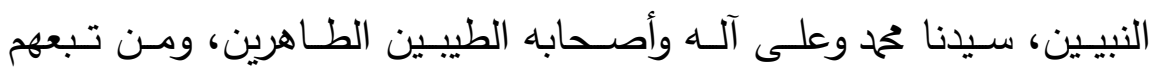
بإحسانٍ إلى يوم الدين .وبعد:

فالعلاقة الزوجيـة بين الرجل والمرأة سنة إلهيـة، وغريزة أودعها الله فيهما ولم يترك الثارع الحكيم هذه العلاقة دون توجيه وبيان لما يجب على كل طرف نحو الآخر ، ومـا تمليه ضـرورة هذا الاقتران مـن حقوق بحيث

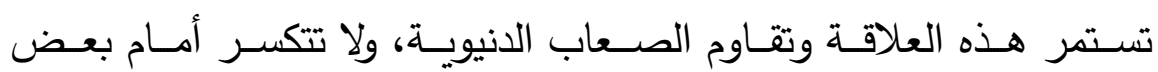
الاضطرابات التي قد تحدث للأسرة.

وفي بيان هذه الحقوق حفظ للأسرة المسلمة والتي هي بدورها لبنة

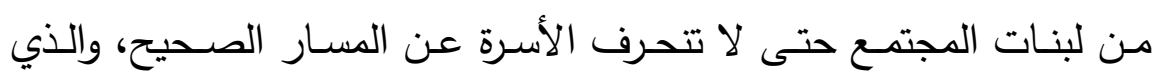

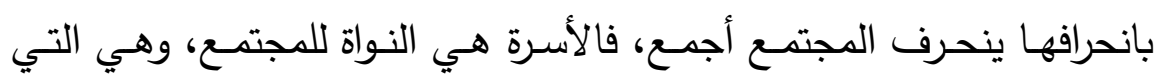
تشكل لحمته وبصلاحها يصلح المجتمع، وبنسادها يفسد.

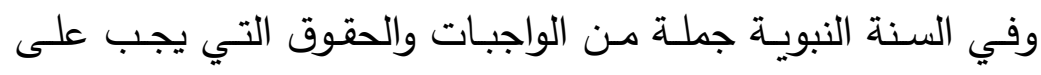
الزوجين الالتزام بها طاعة لله سبحانه أولاً، وحفاظاً على كيان الأسرة ثانياً، وعلى هدوء واستقرار وسلامة المجتمع ثالثاً. فهي سياج آمن يحفظ سـلامتها وأمنها وهدوء ها وانسجامها وتوافقها. وقد صورتها السنة النبوية في صور كثر وسترات فيها التوجيه والإرشاد، وكثفت النقاب عما لكل من الزوجين من حقوق وما عليه من واجبات. ومن ثمّ كان اختياري لموضـوع هذا البحث: (البلاغـة النبوية في الحقوق الزوجية) دراسة بلاغية في الصحيحين. 
وقد انتظم البحث في مقدمة، وثلاثة مباحث، وخاتمة. أما المقدمة: ففيها أهميته، وخطته، والمنهج الذي تسير عليه الدراسة. والمبحث الأول: حقوق الزوج على زوجته. والمبحث الثاني: حقوق الزوجة على زوجها. والمبحث الثالث: حقوق الزوجين المشتركة. وأمسا الخاتمـة: ففيها أهم نتائج البحث، ثم أعقبتها بفهرس للمراجع وآخر

$$
\text { لموضوعات البحث. }
$$

اتبعت في هذا البحث المنهج التحليلي، حيث قمت بذكر الحديث الذي يرد فيه حق من الحقوق، وتخريجها من الصحيحين، علماً بأنـه قد يرد في الحديث الواحد أكثر من حق فأشير إلى ذلك في موضع ورود الحديث خشية

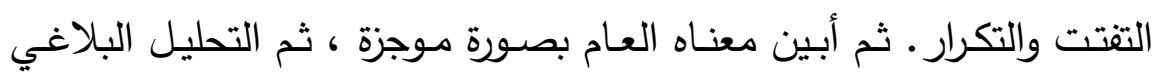

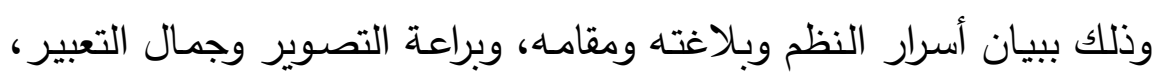

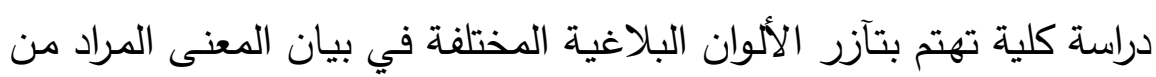
الحديث، ومناسبتها لتحقيق الهدف منه.

والله تعـالى أسـأل أن أكـون قد وفقـت في اختيـار الموضـوع ودراستهـ، وسلامة نتائجه، وأن يغفر لي الزلات، ويتجاوز عن العثرات، وأن يجعل هذا العمل خالصاً لوجهه، وأن ينفعني به، إنه ولي ذلك وان والقادر عليه وليه. وصلى الله على سيدنا ححم وعلى آله وصحبه وسلم. دكتور / محم مصطفى محمود ليلة

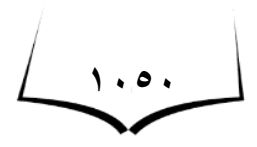




\section{المبحث الأول: هقوق الزوج على زوجته.}

من أعظم الحقوق حقوق الزوج على الزوجـة ، بـل إن حقـه عليها

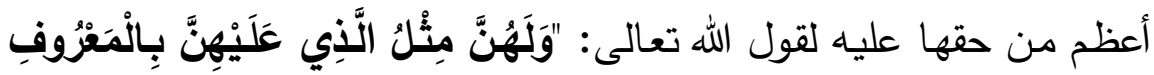

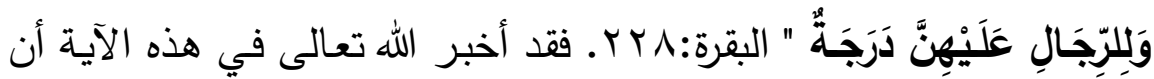
لكل واحد من الزوجين على صاحبه حقاً، وأن الزوج مختص بحق لله عليها

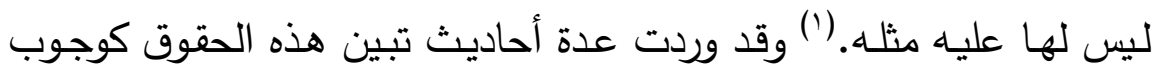
طاعته ما لم يكن في معصية وحسن عشرته، وتمكينه من الاستمتاع، وعدم التصدق من مالـه إلا بإذنـه، وعدم الإذن لمن يكره الزوج دخولهه، وحقه في التأديب..وقد جاءت السنة النبوية سالكة النهج نفسه الذي سلكه القرآن الكريم معتمدة في كثير من الأحيان على الترغيب والترهيب، وقد ورد بعض من ذلك في الصحيحين ومن ذلك:

\section{هق التأديب}

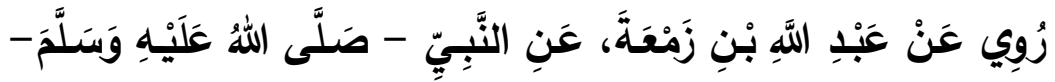

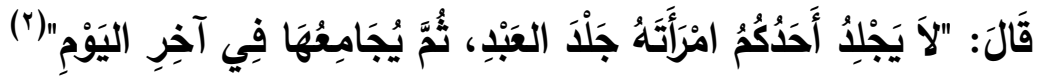
من تكريم الإسلام للمرأة أن نهى الزوج أن يضرب زوجته بلا مسوغ، وأوجب على الزوج حسن معاشرة زوجه، وجعل لله القوامـة بما تفرضـه عليه من مسئولية وتكليف، وجعل له الحق في تأديبها حيث يبدأ التأديب بالوعظ ، فإن لم تمتثل كان الهجر في المضاجع ، فإن لم تمتثل كان الضرب وإنما

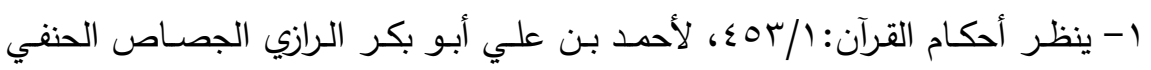

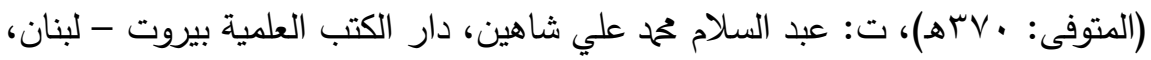

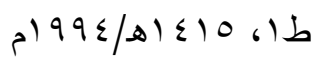

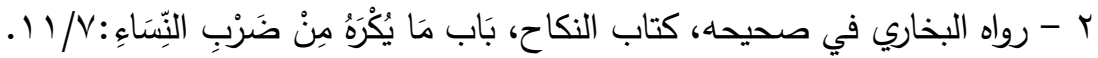

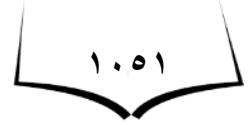


هو ضـرب للحاجـة وللتأديب، غير مبرح، تصـحبه عاطفة المربي والمؤدب

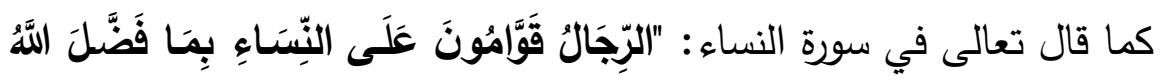

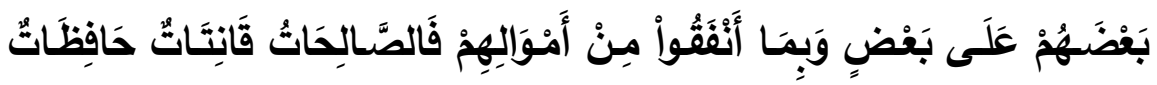

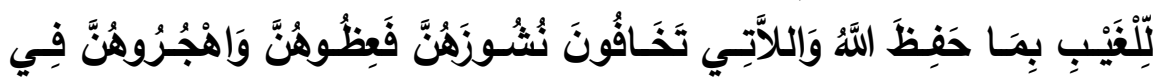

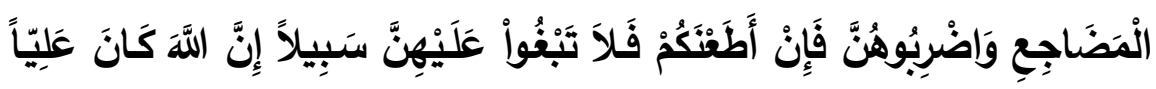
كَبِيراً" النساء: ع ؟. ولا ريب أن الاغتفار والسماحة وعدم الضرب أشرف من ذلك كمـا هو أخـلاق رسول الله - صـلى الله عليه وسلم -، وقد أخرج

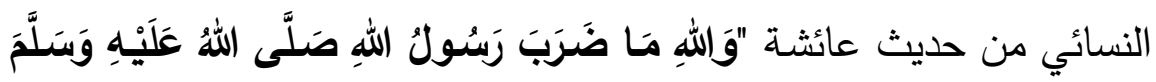

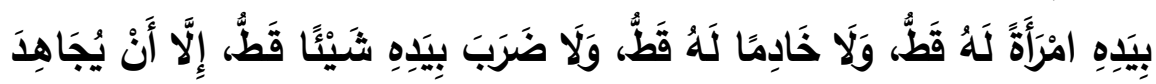
فِي سَبِيِلِ اللهِ..."(1) وقولـه:"لا يَجْلِدُ أَحَدُكُمُ امْرَأَتَـهُ جَلْدَ العَبْدِ" نهي ارتدى ثُب الخبر ، للاهتمام والاعتناء بثأن المنهي عنه، وهو مجاوزة الحد في ضرب الزوجة، وللتأكيد على طلب الامتثال حتى كأنه امتثل وأخبر عنه، ولذا جاء النهي في صورة الخبر ، يؤيد ذلك رواية: " لاَ يَجْلْد" بالجزم.

وفي ذلك إرشاد لإنقاذ كيان الأسرة من الضياع والفشل، فكان حقاً على الزوج تأديب زوجه الناشز وإن وصل التأديب للضرب فلا يتجاوز الحد فيـه، ولئلا يتسرع الزوج الغاضـب لنشـوز زوجـه في تطليقها، فذلك أبغض

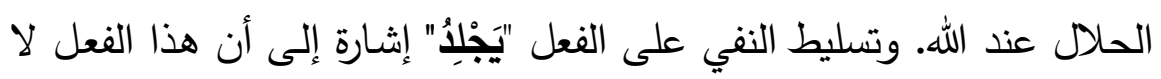
يكون، ولا يصح أن يقع.

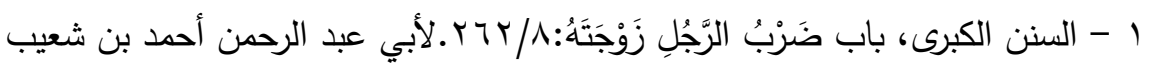

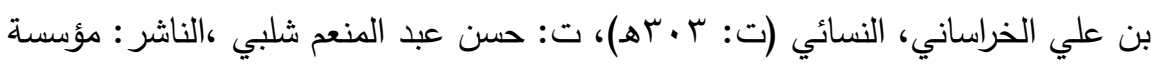

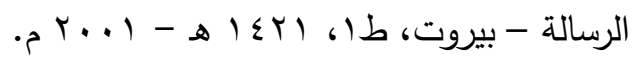

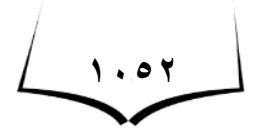




\section{مجلة قطاع كليات اللفة العربية والشعب المناظرة لها العكد [r]]}

والتعبيـر بـ "يَجْلِدُ" دون يضـرب مـثلاً إثـارة إلى الإيـذاء البـدني

والجسدي، فهو مأخوذ من الجِلْد لأنـه موضـع الإحساس في الجسد، كما ورد

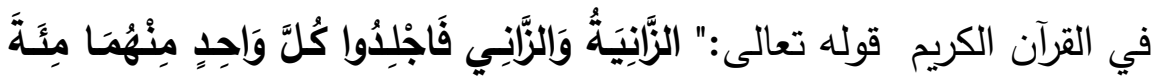
جَلْدَةٍ النور :Y. حينما قصد الإيذاء الجسدي لأجل العقاب والحد أو التأديب.

وفي تعريف "أَحَُكُكُ امْرَأَتَهُ" بالإضـافة إلى ضمير نفسه إثـارة إلى أن كل ما سيلحق بزوجته من أذى كأنه لاحق باه، وهذا يوحي بالسماحة والعفو

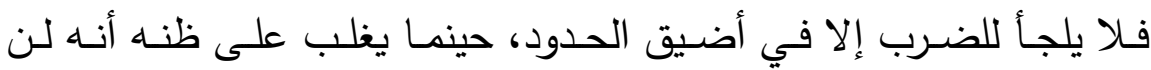
يصلحها إلا هو، وذلك إذا لم يُجدِ معها الوعظ والهجر . فقد أمر الله بهجر

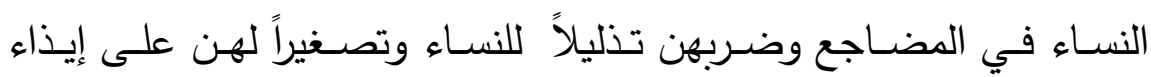
بعولتهن، ولم يأمر في شيء من كتابه بالضرب تصريحاً إلا في ذلك وفى الحدود العظام، فسـاوى معصيتهن لأزواجهن بمعصية أهل الكبائر، وولّّى

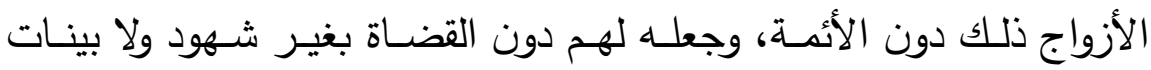

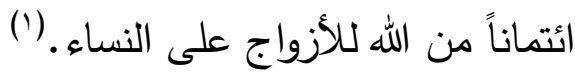

والتعبير بـالمرأة دون الزوجـة في قولـه:"(مْرَأَتَهُهـ" لأن المقام دقام جلد وتعذيب فـلا يتناسب معـه التعبير بالزوجة والتي يعبر بها - غالباً - عند الانسـام والتوافـق بـين الـزوجين كمـا فـي قولــه تعـالى في شـأن سـيدنا

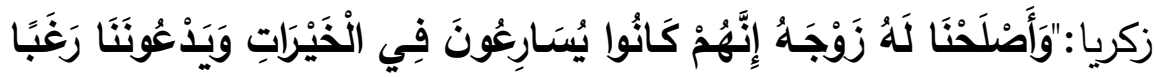

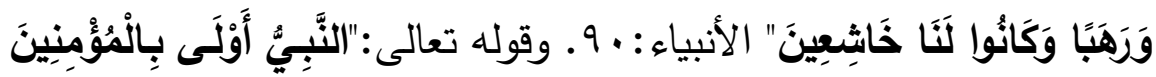

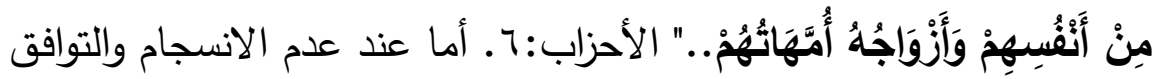

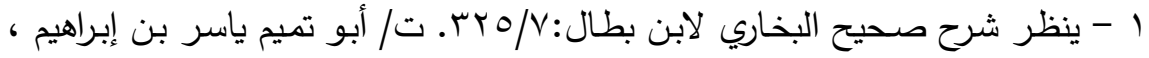

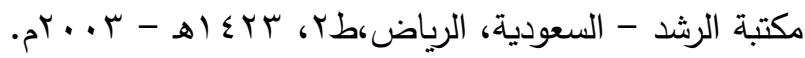

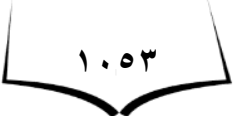




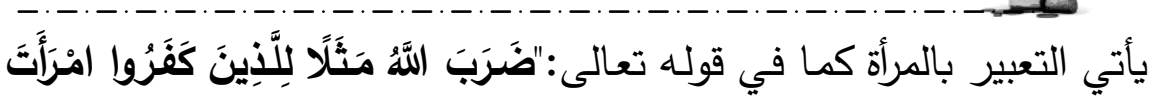

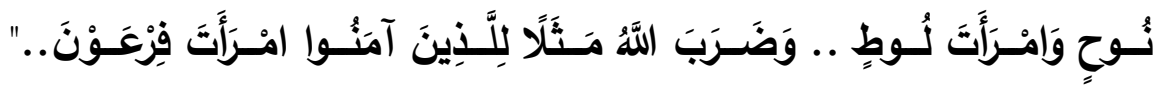
التحريم: (1، ـ ( ـ وذلك مما ييرز تآنق التعبير بالمرأة هنا، وأن البيان النبوي

يسير على خطى البيان القرآني.(1) وفي قوله:" جَلْدَ العَبْدِ" تشبيه بليغ صور تقبِيح وتتفير تلك الفعلة، وكأنه لا توجد علاقة بينه وبينها، وكأنها عنده عبد آبق، وهذا لا يليق ؛ والتقدير : لا يجلد أحدكم امرأتـه جلدًا كجلد العبيد؛ لأن علاقـة الرجل مـع زوجته علاقة خاصـة ينبغي أن تكون مبنية على المحبة والألفة والبعد عن الفحش ، فالجلد ليس من طبيعـة العلاقـة الزوجيـة الكريمـة، ولا مـن طبيعـة

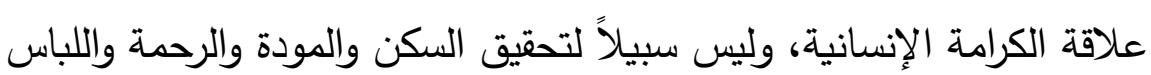

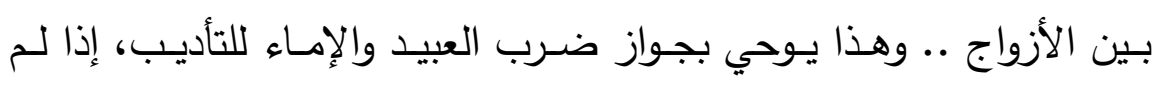
ينزجروا بالكلام، وكذا حسن المعاشرة مع النساء والرفق بهن. والتعبير بـ "العَبْدِ" تشـير إلى أن للمرأة شخصسية مستقلة يجب أن يحافظ عليها الزوج، ولا يتعامل معها كأنها ضمن أملاكه يفعل بها ما يشاء، لئل

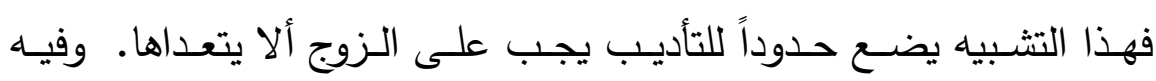
تعريض بالهجر الذي بيّنه الله في قوله: "وَاَهُجُروهُنَّ" - وإن كان مرحلة من

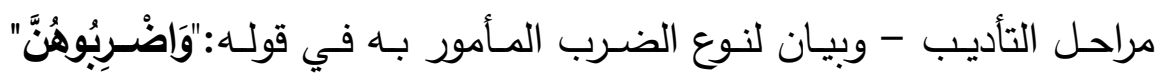

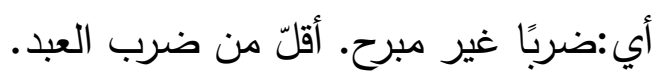

(1) ينظر : خصائص التعبير القر آني وسماته البلاغيةأ. د عبد العظيم المطعني( (197) بتصرف.

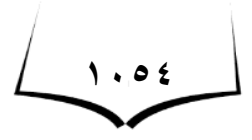




\section{مجلة قطاع كليات اللفة العربية والشعب المناظرة لها العكد [r]]}

وقوله:" ثُُمَّ يُجَامِعُهَا فِي آخِرِ الَيَوْمِ" وقع موقع التعليل؛ للنهي عن

الضـرب المبرح الذي يقصد بـه التشفي، والانتقام، والتعذيب، وإهانـة المرأة، والتقدير : وهو يضاجعُها، كأنه قيل: كيف يجلدها وهو بصددِ أن يجامعَها في آخر اليوم، فربمـا تعذر عليه ذلك لمـا أسـاء من عشرتها. وفي هذا تقبيح الضرب وقرب ما يناقضـه؛ لأن المرأة إذا عرفت قرب الرجعة وسرعة الفيئة، لم تعبأ بأدبه وإيذائه. و "ثَُّّ" استبعادية أي: مستبعد من العاقل الجمع بين هذا الإفراط والتفريط من الضـرب المبرح والمضـاجعة، ففي سياقه استبعاد وقوع الأمرين من العاقل، أن يبالغ في ضرب امرأته ثم يجامعها من بقية يومه أو

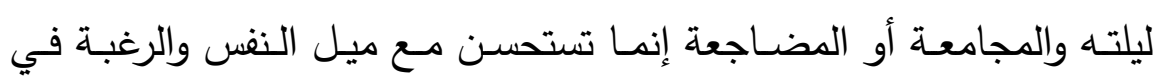
العشرة والمجلود غالباً ينفر ممن جلده فوقعت الإشـارة إلى ذم ذلك وأنـه إن كان ولا بد فليكن التأديب بالضرب اليسير بحيث لا يحصل منه النفور التام فلا يفرط في الضرب ولا يفرط في التأديب. (') فهذه الجملة تثير في النفس بال تعجباً، إذ كيف يجلدها ثم يقبل في آخر اليوم على معاشرتها! إن النفس السوية لا تقبـل هذا الفعـل ولا تقدم عليـه، حيث لا يتحقق السكن والمـودة والرحمة المقصود الأسمى للزواج. لون.

والحديث كناية عن تهذيب ذوق الرجل مع زوجته، وحسن معاشرتها، والإحسان إليها، والنهي عما من شأنه الإساءة إليها.

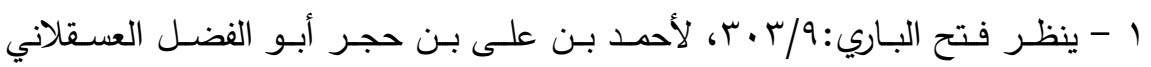

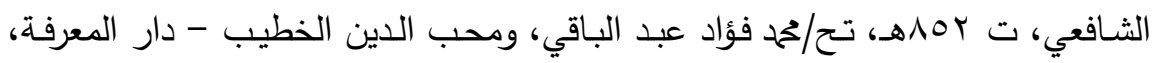

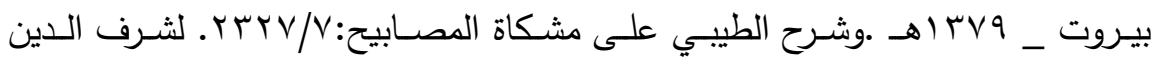

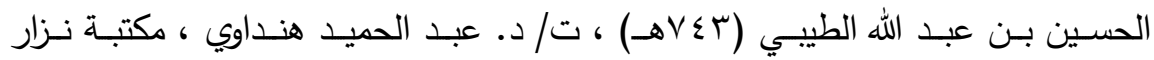
مصطفى الباز (مكة المكرمة - الرياض).

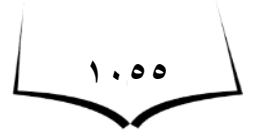




\section{لا تأذن في بيته إلا بإذذنه.}

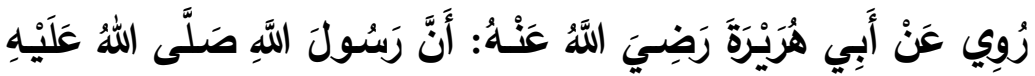

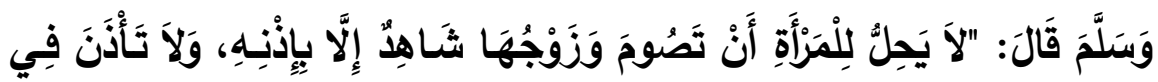

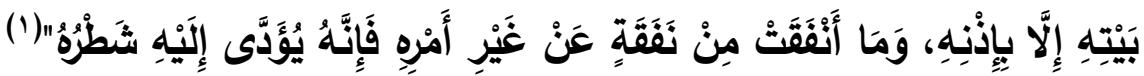
في هذا الحديث بيان لبعض من حقوق الزوج على زوجه، حيث بيّن أنه لا يحل لها أن تصوم صيام تطوع وزوجها حاضر معها إلا بإذنه، فله حق الاستمتاع بها في كل وقت، حتى لا يضيع حقه، والنفل تطوع لا تأثم

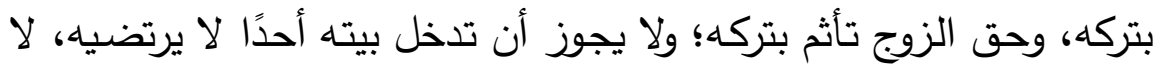
امرأة ولا رجلًا، لا من المحارم ولا من غير المحارم، لأن سلطانه في بيته، وهذا مـن رعايتها لحق زوجها، فالمرأة راعيـة في بيتها وهي مسئولة عن مهن رعيتها، ولا تتصدق من ماله إلا بإذنه، وإذا تصدقت بصدقة غير مفسدة فيها وتعلم رضا الزوج بها في العادة فله نصف الأجر ولها النصف الآخر جزاء

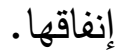

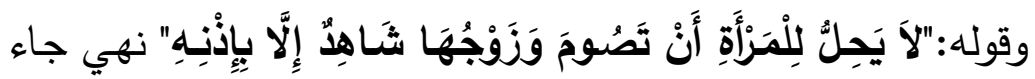

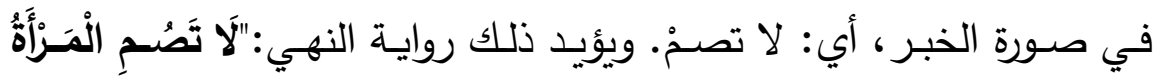

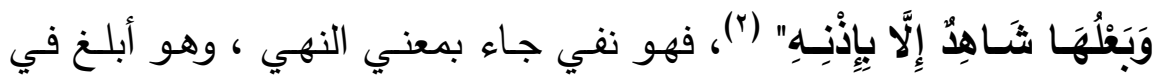
الدلالة على معني النهي، لأنه يدل على تأكد الأمر فيه فيكون تأكده بحمله

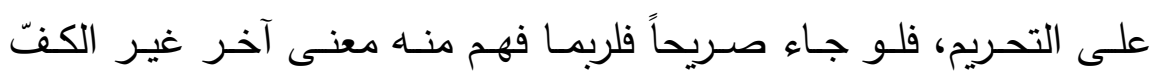

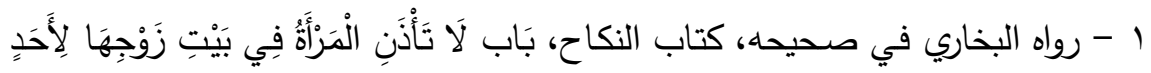

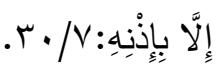

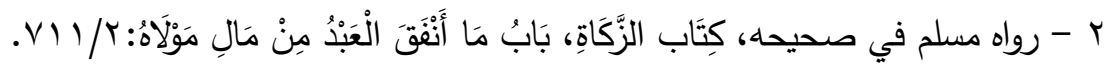

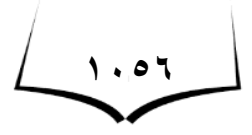


والتحريم وذلك من المعاني التي يخرج إليها النهي، كالنصسح والإرشاد وغيره،

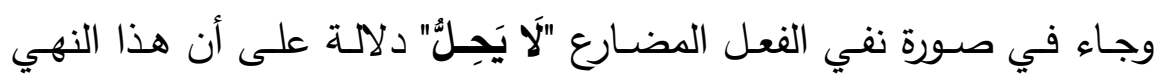
والتحريم متجدد ومستمر إلى قيام الساعة، فهو من الأخبار التشريعية التي

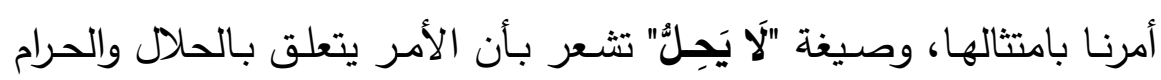

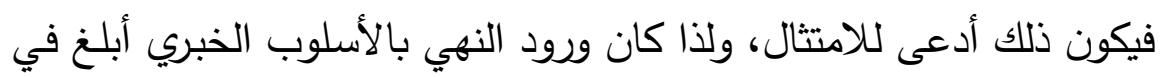
النهي، وتهديد من عدم الامتثال، ففي ذلك خطر عظيم على الأسرة وقوتها

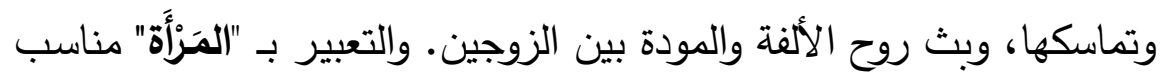

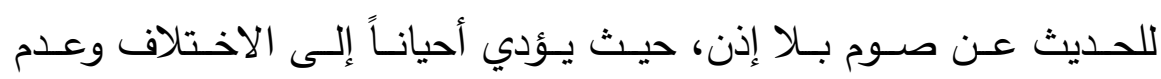
الانسجام.

وفـي التعبيـر بـ "أن" والفعـل "تَصُــومَ" دون المصـدر (صـومها أو صيامها) دلالة على أن هذه الحكم متجدد ومستمر لصيام النافلة وذلك عام لكل امـرأة زوجها شـاهد، بخـلاف التعبير بالمصدر فيتحقق بالامتثال مـرة واحدة.

وجاء أسلوب القصر ليقصر حلّ صـوم المرأة تطوعاً على موافقة الزوج بالنفي والاستثناء مؤكداً هذا الأمر ومشدداً عليه، وليس في هذا تقييدُ لحرية المرأة في العبادة، فالحرية الحقيقية هي المستمدة من العبودية المطلقة لله وحدَه، فإذا استشعر الإنسان هذه العبودييًَ تحرَّر من كل عبودية سواها،

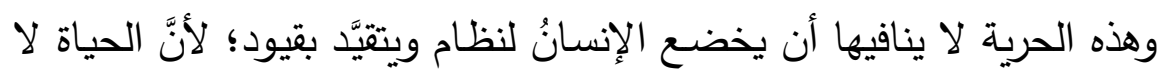

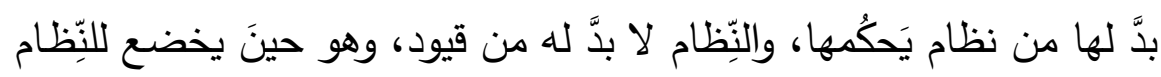

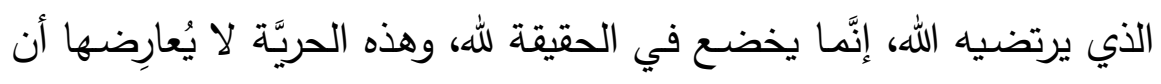

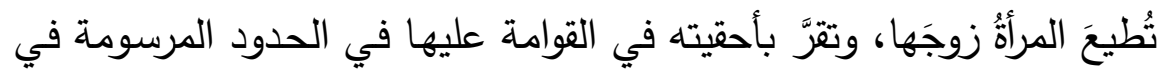
شريعة الله؛ لأنَّها حين تُطيعه لا تَفقد كيانها ولا شخصيتها، ولا يُنافي شيء 
من هذه الأشياء جميعها الحريَّة؛ لأنَّها حريةُ الإنسان الراقي الذي يُعطِي كلَّ

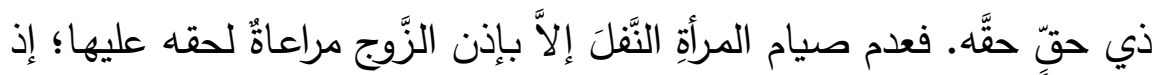
إنَّ المـرأة لا تؤدِّي حقَّ ربها حتى تؤَدِي حقَّ زوجها وأهمها الطاعـة، قـال

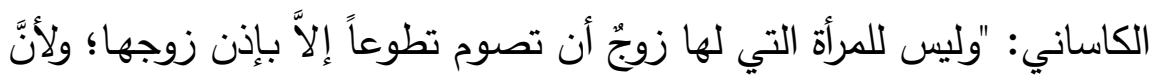

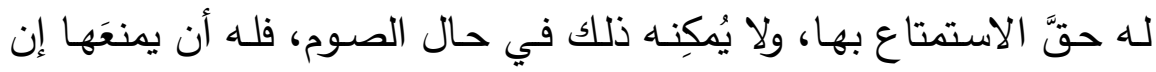
كان يضرُه، فإن كان صيامها لا يضرهُه بأن كان صـائماً أو مريضـاً لا يَقدِر على الجِمـاع، فليس لـه أن يمنعها؛ لأنَّ المنع كان لاستيفاء حقِّه، فإذاذا لـ يقدر على الاستمتاع، فلا معنى للمنع، ولا يبعد أن يكون النهي لما للزوج من حقوق غير التمتع كالمحافظة على صـــها ونضـرتها أو على قدرتها على أداء أعمالها في منزلها ورعايتها لأولادها أو على وفرة لبنها إذا كانت مرضعة أو نحو ذلك، وعليه فليس لها مهما كان مريضاً أو محرماً أو صائهاً

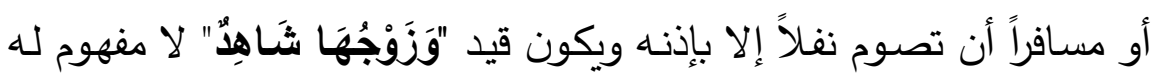

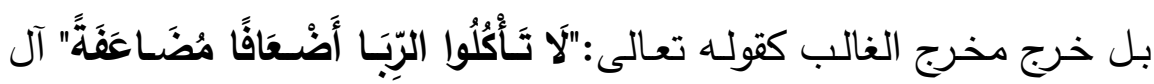

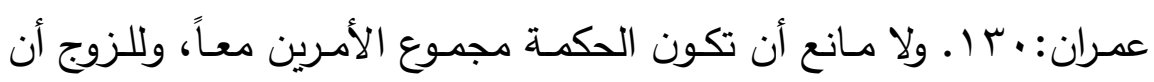
يفطر المرأة إذا صامت بغير إذنه وكذا للمولى... " (') والتعبير بصيغة الشهادة "شَـاهِدِ" دون حاضـر أو موجود مثلاً زيـادة في التأكيد عليها بعدم الصـوم إلا بإذنه، وكأنه يشهد على صيامها ويقره،

I - ينظر بدائع الصنائع في ترتيب الشرائع:Y/Y • 1، لعلاء الدين، أبو بكر بن مسعود

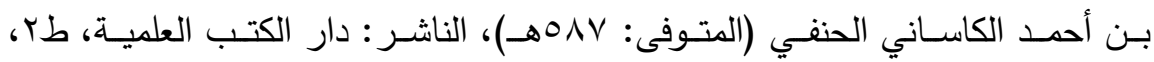

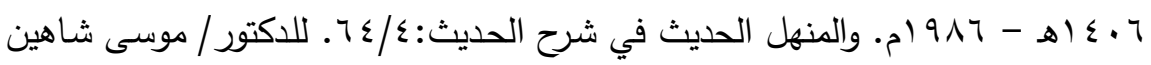

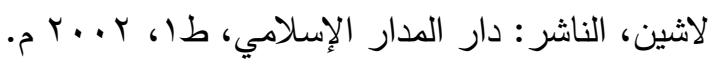

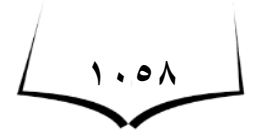


وهذا لا نجده لو عبر بلفظ آخر ، وهذا من بديع اختيار الكلمة في البيان النبوي.

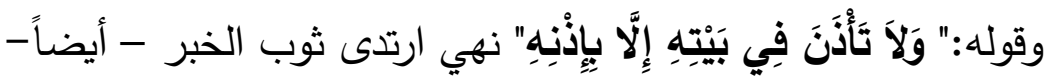

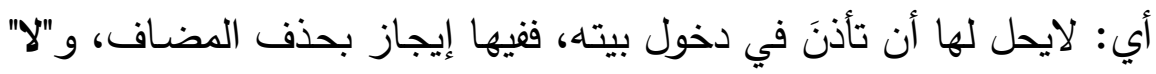
مزيدة للتأكيد. وتتاغم هذا الحذف مـع المقام حيث لا يجوز لها أن تأذن في

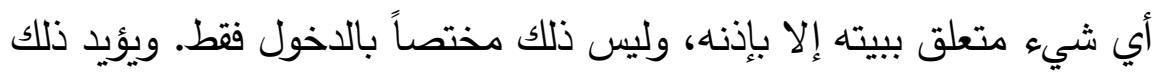

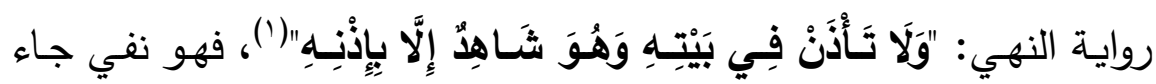
بمعني النهي، وهو أبلغ في الدلالة على معني النهي، حيث جاء في صورة النفي المحض إشارة إلى أنه ينبغي أن لا يوجد ـ وفي تقييد المنع على هذه

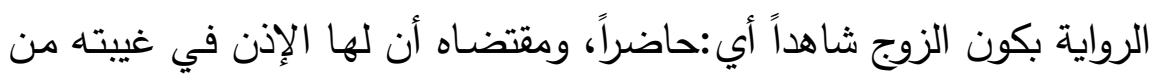
غير استئذانه، ولم يذكر هذا القيد في رواية البخاري، والأخذ بالإطلاق هنا أولى فـإن غييته في ذلك كحضـوره بـل أولى بـالمنع، فقد يسمح الإنسـان بذخول الناس منزله في حضوره ولا يسمح بذلك في غيبته وحينئذ فذكر القيد

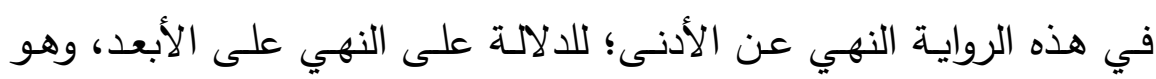
غياب الزوج وهذا أبلغ من النهي عن الأبعد مباشرة، وقد خرج مخرج الغالب الب التهني في أن الإذن للضيفان ونحوهم إنما يكون مع حضور صاحب المنزل أمـا إذا كان مسافراً فالغالب أن لا يطرق منزله أصسلاً، ولو طرق لم تأذن المرأة في دخوله... وهو محمول على ما لا تعلم رضا الزوج به، أما لو علمت رضـا الزوج بذلك فلا حرج عليها كمن جرت عادته بإدخال الضيفان موضعاً معداً

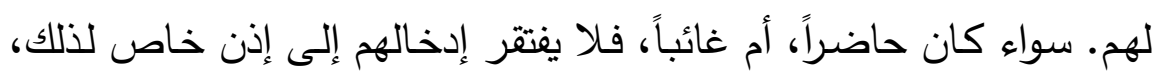

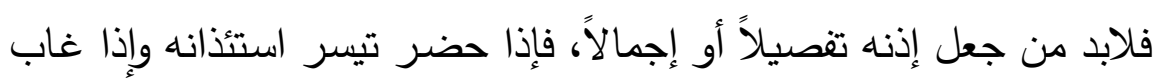

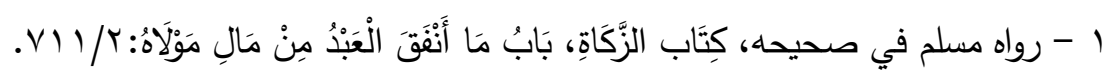

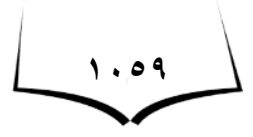


تعذر، فلو دعت الضرورة إلى الدخول عليها لم تفتقر إلى استئذانه لتعذره. (') وفيـه إشـارة إلى أنـه لا يفتات على الزوج وغيره من مـالكي البيوت وغيرهـا

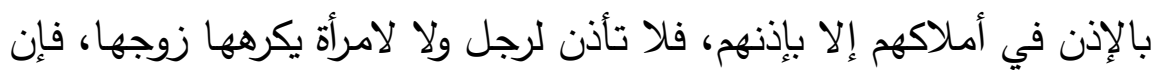
ذلك يوجب سوء الظن، ويبعث الغيرة التي هي سبب القطيعة، ويحتمل أن يكون المراد الإذن في الدخول عليها، ويحتمل أن يراد مطلق دخول البيت، وإن لم يكن فيه دخول عليها بأن أذنت في دخول شخص في مكان ليست فيـه، إمـا من حقوق الدار التي هـي فيها وإمـا في دار أخرى منفردة عن سكنها، وهذا الاحتمـال الثاني هو مقتضسى اللفظ فإنـه ليس فيه تقييد ذلك بكون الاخول عليها- والله أعلم. (r) . وقصر إذن دخول بيته على موافقة الزوج بالنفي والاستثناء مؤكداً على

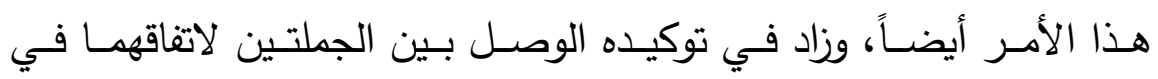
الإنشائية معنى، يزيده - أيضاً - تأكيداً إضافة البيت إلى ضميره "بَيْتِهِهِ.

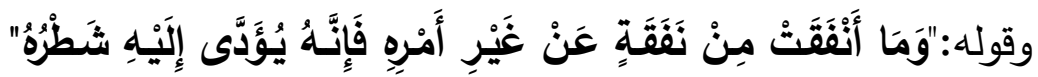
فمعناه: من غير أمره الصريح في ذلك القدر المعين، ويكون معها إذن عام سابق صريحاً أو عرفاً متناول لهذا القدر وغيره، لأنـا جعل الأجر مناصفة،

1 - ينظر طرح التثريب في شرح التقريب:ء/ آ ا ـ لأبي الفضل زين الدين عبد الرحيم

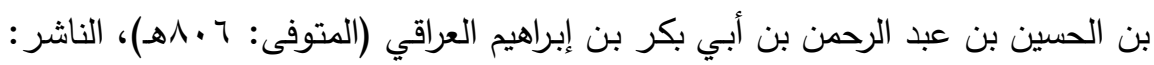

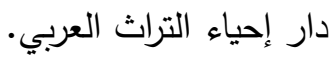

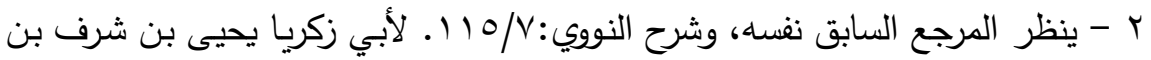

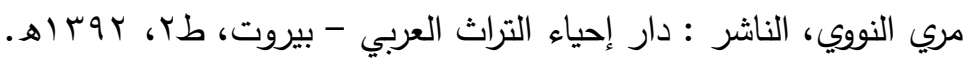

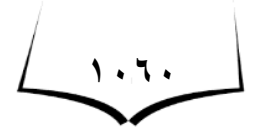


ومعلوم أنها إذا أنفقت من غير إذن صريح ولا معروف من العرف فلا أجر

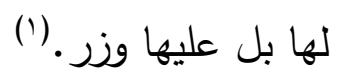
وفي تتكير "تَفََقةٍة" دلالة على التقليل، فما من نفقة أنْفِتَ، قَلّت أو كثرت إلا ولها الجزاء الأوفى من الله - جل وعلا- فلمرأة شطر الأجر جزاء إنفاقها وللزوج الشطر الأخر جزاء كسبه، وبناء الصيغة للمفعول في " يُوََََّى"

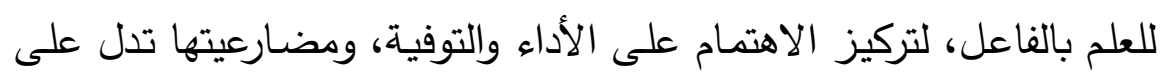
تجدد واستمرار ذلك ما دامد مستمرة في الإنفاق، قال تعالى :" فَمَن يَعْمَلْ

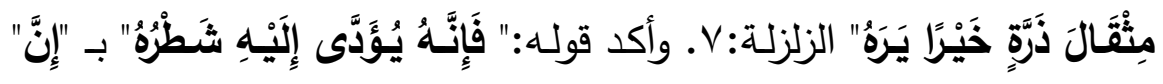

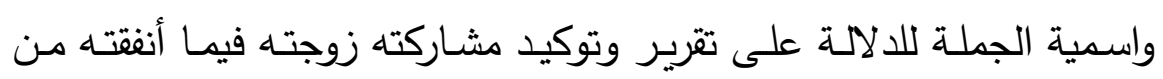
ماله، فشطر ذلك يؤدي إليه .

\section{شكر نمهمته عليها}

روي عَنْ أَبِي سَعِيٍٍ الخُدْرِيّ - رضسي الله عنـهـ- قَالَ: خَرَجَ رَسُولُ

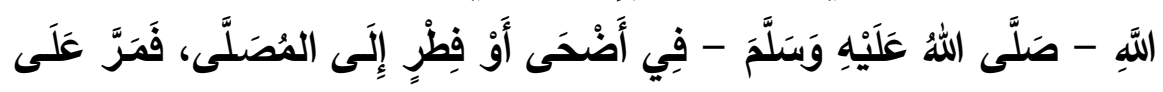

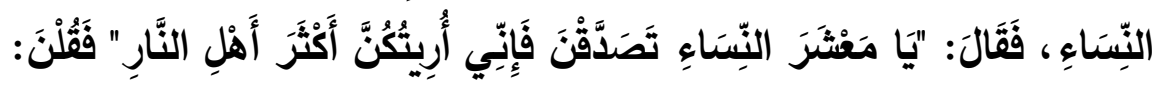

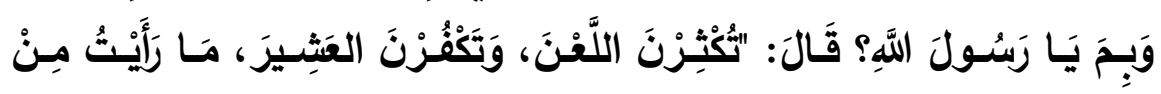

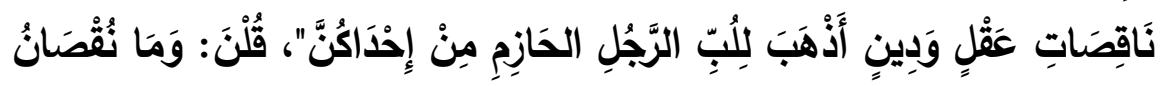

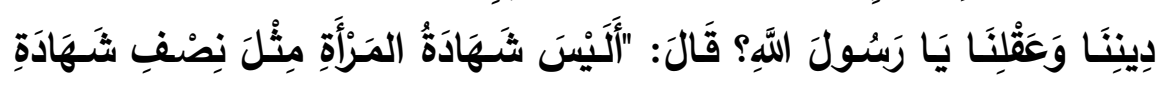

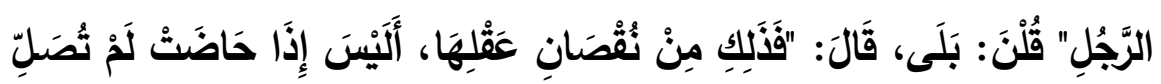

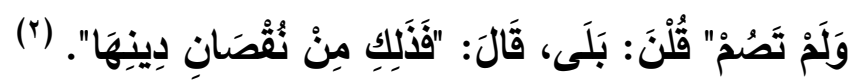

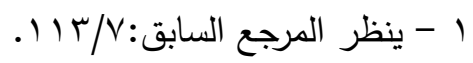

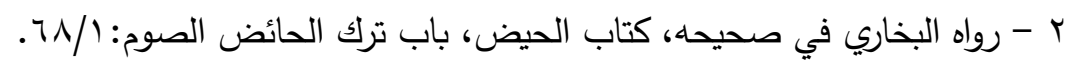

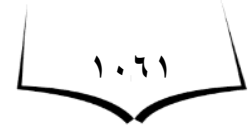


في هذا الحديث بيان لحق الزوج في شكر زوجته نعمتَهُ عليها وحقها في التصدق فالنبي - صلى الله عليه وسلم - بعدما وعظ الرجال في يوم عيد أتي النساء لوعظهن وتذكيرهنَّ بما يجب عليهنَّ وحثهنَّ على الصدقة

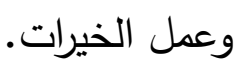

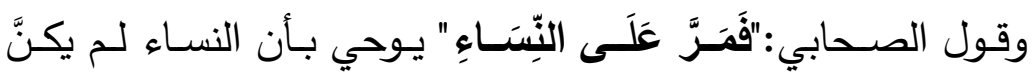

مختطات بالرجال، فمجلسهن خاصٌ بهن إذ ذهاب النبي - صلى الله عليه وسلم - لهن ليعظهن بعدما وعظ الرجال يشعر بأنهن كن على حده من لـ لـ لهن

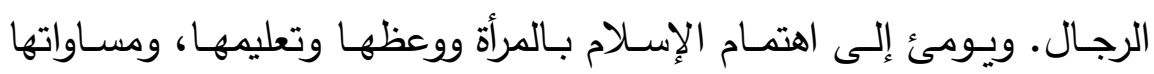
الرجل في حق التعلم والوعظ والنصح والإرشاد. وجاء التعبير بـ "يَـا" الموضـوعة لنداء البعيد في قولـه:" يَا مَعْشَسرَ

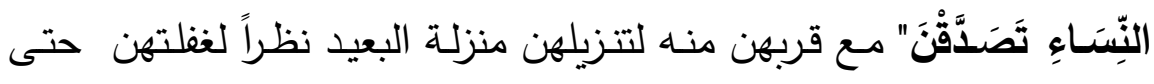
يحرصن على الإقبال عليه، ولا يغفلن عن نصحه، ولبيان عظم ما نودين

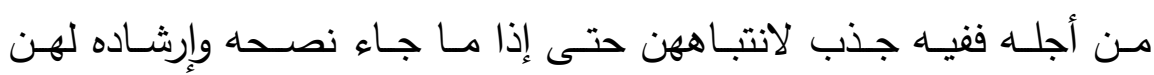
بقولـه:"تصَسدَّقُنَ" زالت غفلتهن وتمكن في الذهن أيمـا تمكن. ولـذا تصـدر خطابـه لهـن بالنـداء لشدّ الانتبـاه لأمـر يخصـهن تـلاه بـالأمر الذي نـودين

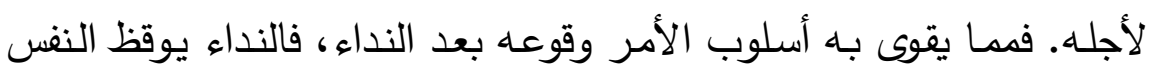

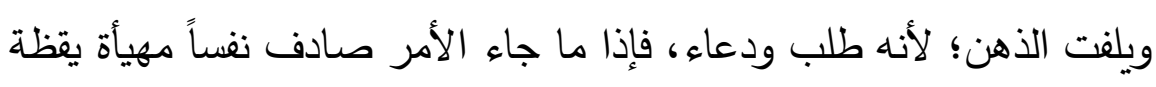
فيقع منها موقع الإصابة، حيث تتلقاه بحس واع وذهن متتبه، وهذا دليل على عناية الآمر بأمره ورغبته في إعداد النفوس لتلقيه.( (1)

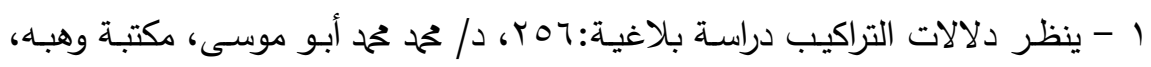

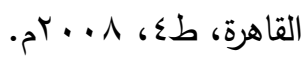

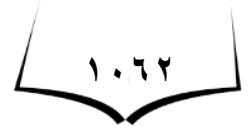




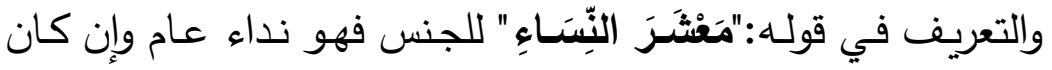

المتبادر منـه المخاطبات من نساء المهاجرين والأنصـار ، فهو يعم ويشمل جميع النساء، وفي قوله:"تَصَدََّقْنَ" إيجاز بحذف المفعول وذلك ليعم ويشمل الفرض والنفل، القليل والكثير •

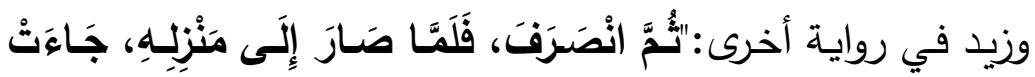

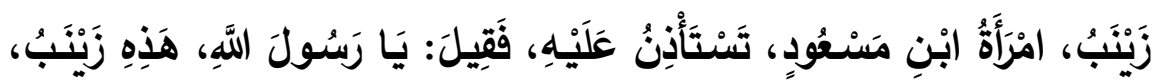

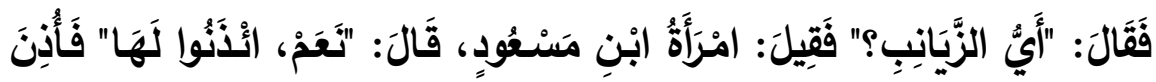

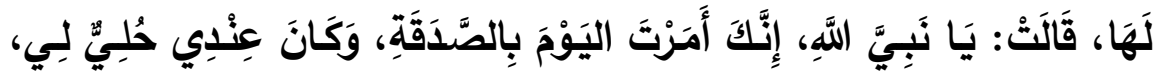

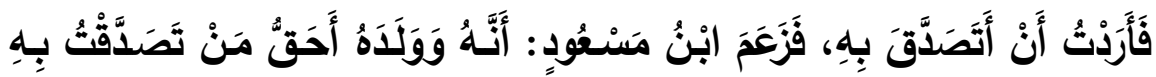

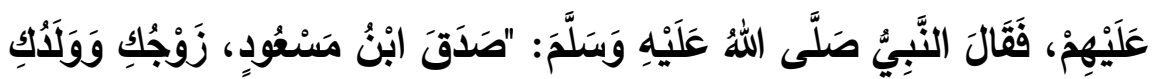

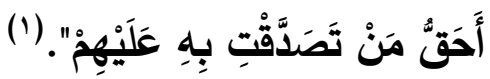

مما يدل على شدة حرصهن على امتثال الأمر، فها هي زوج عبد الله بن مسعود - رضـي اللَّه تعالى عنهما - تتبع النبي - صلـى الله عليه وسلم إلى بيته لتسأله وتبين له مدى حرصها وامتثالها الأمر بالتصدق، خاصة من مالها وحُلِيّها، ويوحي ذلك بمدى حرصها واستيثاقها الأمر من رسول الله صلى الله عليه وسـلم- بعد أن أفتاهـا زوجها، وقولها: "فَزَعَمَ ابْنُ مَسْـعُودِ" أصل الزعم: يقال للقول الكاذب، ولكن قد يراد بـه الصدق. وقولها: "أَحَقٌُهُ"

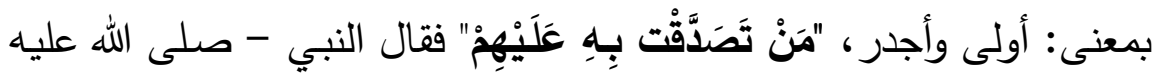

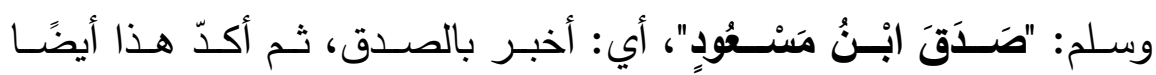

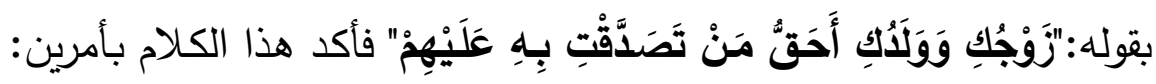

1 - رواه البخاري في صحيحه، كتاب الزكاة، باب الزكاة على الأقارب:؟/ • Y.

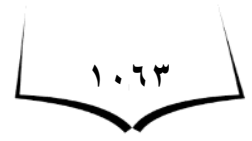


الأمر الأول: أنه قال: صدق. والثاني: أنه أعاد الكلام. فقد كان زوجها فقيراً، وكانت زينب تنفق عليه، وأيتام في حجرها، فقالت لعبد اللَّه: سل رسول اللَّه صلى اللَّ عليه وسلم - أيجزئ عنّي أن أنفق عليك، وعلى أيتام في حجري من الصدقة؟ فقال: سلي أنت رسول اللَّه - صلى اللَّه عليه وسلم - ... ولفظ

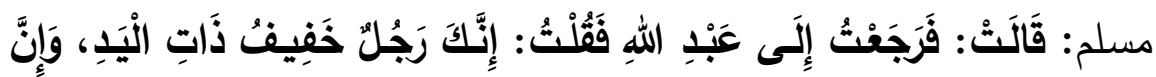

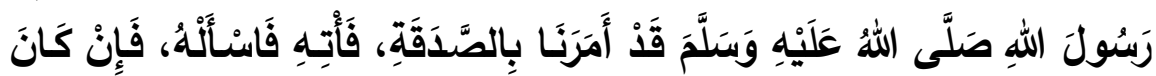

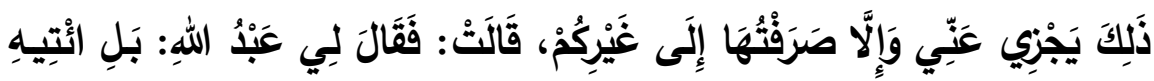
أَنْتِ، ... ". وسبب امتناعه عن السؤال أن رسول اللَّه - صلى اللَّه عليه وسلم - قد أُلقيت عليـه المهابـة". فكما أن زينب هابت أن تسأله فكذلك عبد اللَّه

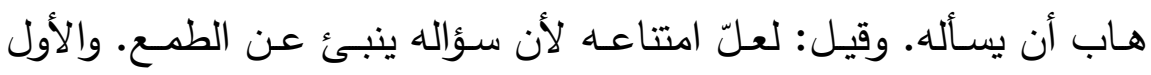

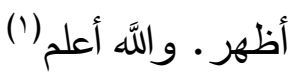

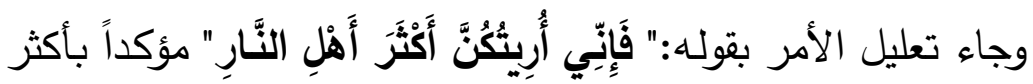
من مؤكد لتوكيد الأمر وبيانه، وزيادة في الحث والترغيب، وأكد ذلك أيضـاً تقـديم المسـند إليـه على خبـره الفعلي، وجـاء بنـاء الرؤيـة للمفعـول لتركيزز

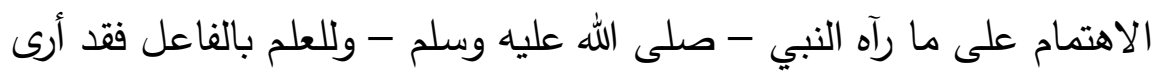

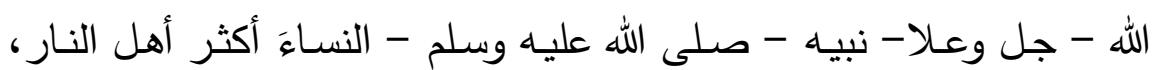
فحذف الفاعل إيجازاً للعلم بـ. وكانت الرؤيسة على طريق الكثف، أو على

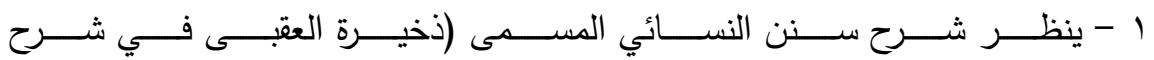

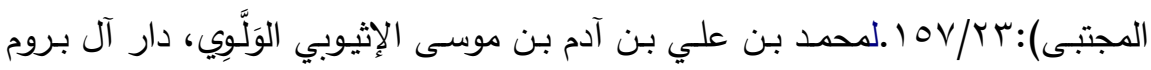

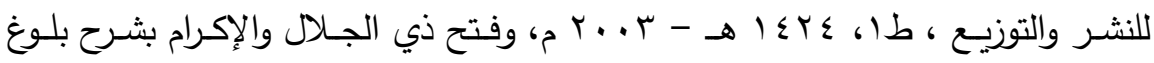

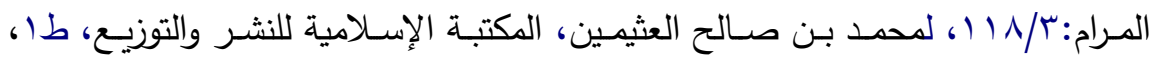

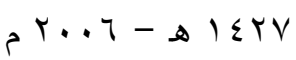




\section{مجلة قطاع كليات اللفة العربية والشعب المناظرة لها العكد [r]]}

سبيل الوحي، أي أعلمت بأنكن أكثر دخولاً في النار من الرجال، والصدقة تقي منها. فكل امرئ في ظل صدقته حتى يقضى بين الناس، واتقوا النار ولو بشق تمرة؛ ولأن علة كونهن أكثر أهل النار محبتهن للدنيا، وبالتصدق يزول، أو ينقص رذيلة البخل الناشئ عن محبتها المذمومـة، ولهذه النكتة

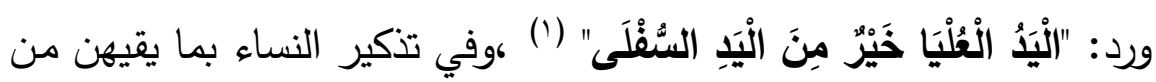
النار وإرشادهن إلى ما يخلصهن من النار دليل على اهتمام الإسلام بالمرأة

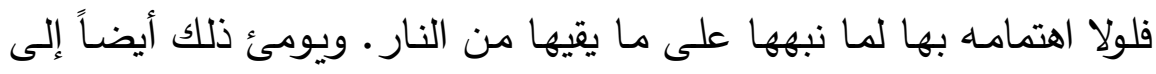
الإغلاظ في النصح ببيان العلة التي تبعث على إزالة العيب أو الذنب الذي يتصف به المخاطب، وبذل النصيحة لمن يحتاج إليها.

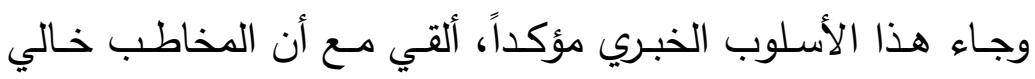
الذهن زيادة في الترهيب، وهذا الأسلوب من شأنه أن يلقي الرعب في قلوب

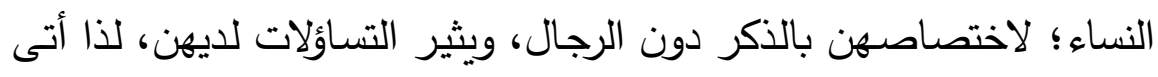
الاستفهام التعجبي من إحداهن: "وَبَِّ يَا رَسُولَ اللَّهِ" وفي مناداتهن النبي صلى الله عليه وسلم - بأداة النداء "يَا"الموضوعة للبعيد مع قربه منهن دلالية على رفعته وعلو شأنه، وعلى تطلعهن لمعرفة سبب كونهن أكثر أهل النار.

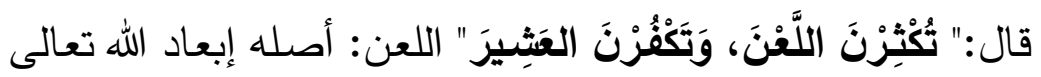
العبد من رحمته بسخطه، ومن الإنسان الدعاء بالسخط والإبعاد على نفسه

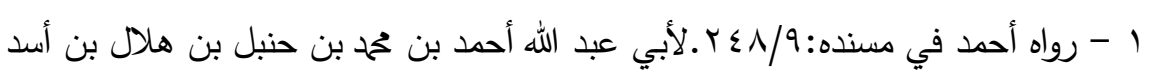

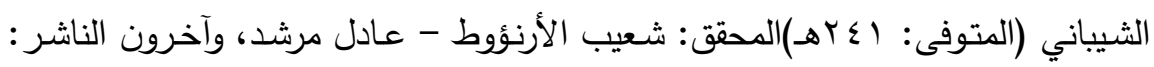

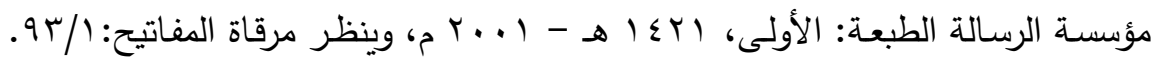

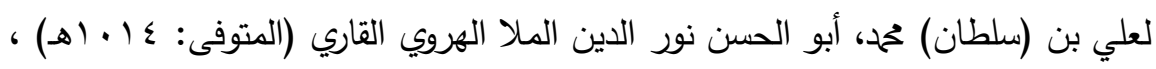

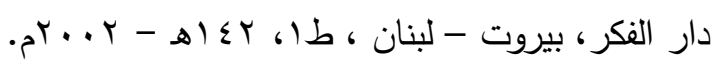

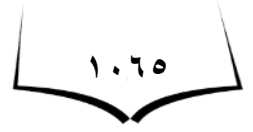


أو غيره. والعشير : المعاشر المالازم، وهو الزوج هاهنا، وكفرانه جحد نعمته وإنكارها، أو سترها بترك شكرها. والخطاب عام غلبت فيه الحاضرات على وائ وهي

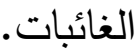

ومضارعية الصيغة في قوله:" تُكْثِرْنَ ، وَتَكْفُزْنَ" تدل على كثرة ذلك منهن وتجدده واستمراره، إلا ما رحم ربي. وفي قوله: " تَكْفُزْنَ العَثِيرَ" إيجاز بحذف المضـاف والتقدير : تكفرن بحق العشير وذلك لبيان أن الجحود قد يتعدى الحقوق إلى الذات، وفي ذلك مزيـــ مـن التهديد والوعيد. داعٍ إلى

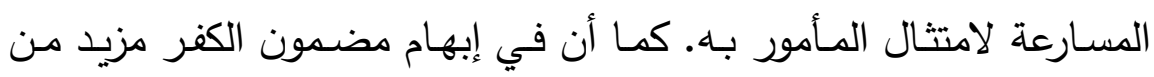

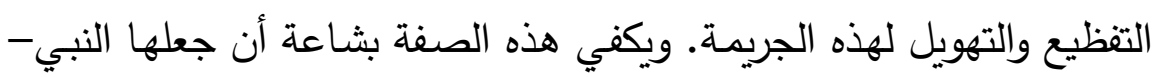
صلى الله عليه وسلم - إحدى الأسباب التي تدخلهن النار، والتعبير بصيغة

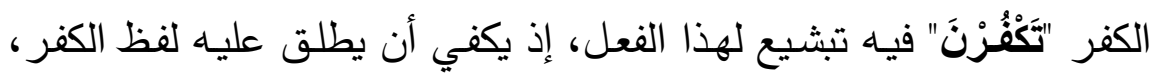
وإسناده إلى نون النسوة دليل على العموم والثمول، فتلك الصفة في معظم النساء إلا ما رحم ربي. وفي التعبير بـ "العَثِير" دون الزوج زجر لهن، إذ من حق العشرة عليها لزوجها أن تعترف له بمعروفه ولا تتكره.

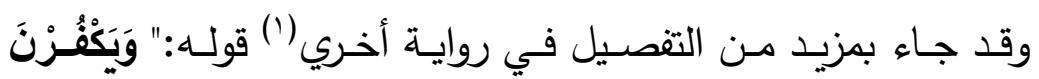

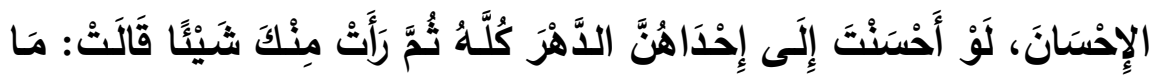

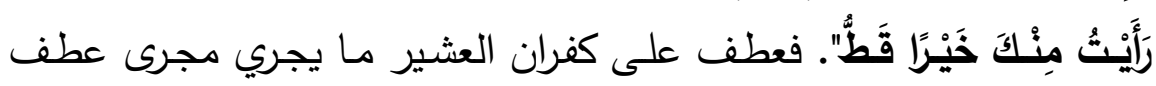

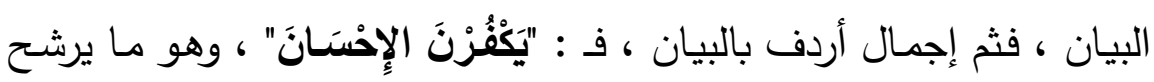
معنى الجحود ، فالكفر إنكار وجحود للشيء وتكذيب وإباء واستكبار عن

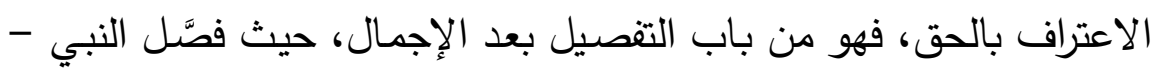

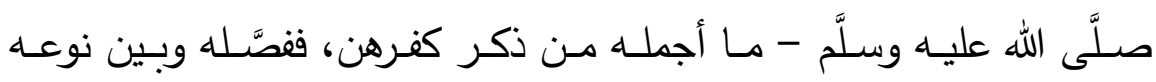

1 - رواه البخاري في صحيحه، كتاب الجمعة، باب صلاة الكسوف جماعة:T/T.

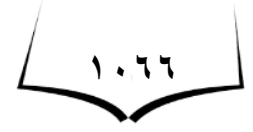




\section{مجلة قطاع كليات اللفة العربية والشعب المناظرة لها العكد [r]]}

وحقيقته، بأنه ليس راجعاً إلى الكفر بالله، ولكنه راجع إلى كفرِ العشير وهو

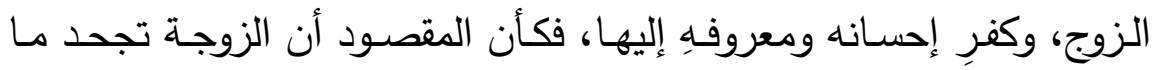
يجب عليها من إحسان عشرة الزوج ورعايةِ حقه، وتجحد إحسانه ومعروفهـ إليها بنسيانه وعدمِ الاعتراف والإقرارِ به وإنكارِ بقولها: " مَا رَأَنْيُّ مِنْكَ خَيْرًا

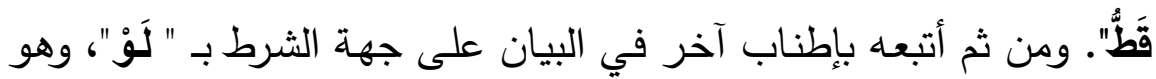

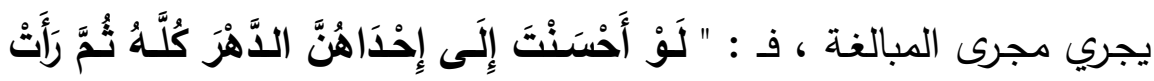

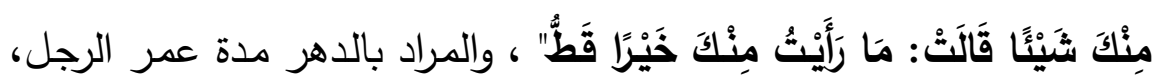

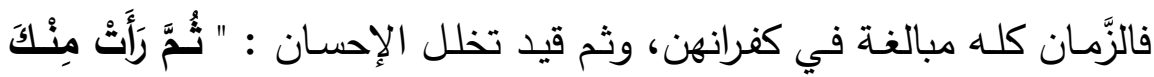

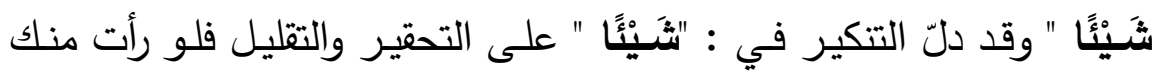

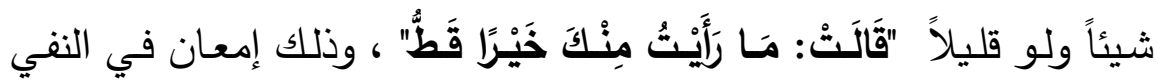
فالنكرة في سياق النفي تعمّ فضـلاً عن التقييد بالظرف الذي ينفي كل خير تقدم!. وفي تكرار الفعل "يَكْفُزْنَ" دلالة على كثرة وقوع الجحود منهن وتتوعِهـ ما بين جحود حقه، وجحود إحسانه.

وقد اتفق العلماء على تحريم اللعن فإنـه في اللغـة الإبعاد والطرد،

وفى الشـرع الإبعاد مـن رحمـة الله تعـالى، فـلا يجوز أن يبعد مـن رحمـة الله تعالى من لا يعرف حاله وخاتمة أمره معرفة قطعية، فلهذا قالوا لا يجوز لعن الن اله أحد بعينه مسلماً كان أو كافراً أو دابة إلا من علمنا بنص شرعي أنه مات على الكفر أو يموت عليه كأبي جهل وإبليس، وأمـا اللعن بالوصف فليس بحرام كلعن الواصلة والمستوصلة والواشمة والمستوشمة وآكل الربـا وموكلـه لـ والمصسورين والظالمين والفاسقين والكافرين .. ومن تولى غير مواليه،، ومن

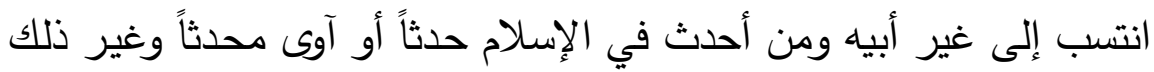


مما جاءت به النصوص الثرعية بإطلاقه على الأوصاف لا على الأعيان

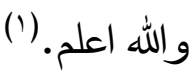

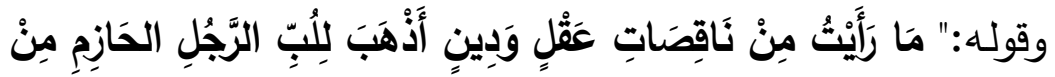

إِحْدَاكُنَّ" ليس المقصـود بـه تقرير قاعدة أو حكم عـام، إنمـا هو أقرب إلى هـ التعبير عن تعجب رسول الله - صلى الله عليه وسلم - من التناقض القائم في ظاهرة تغلب النساء على الرجال ذوي الحزم، و" مِنْ " مزيدة للاستغراق، مهن صفة لمفعوله المحذوف أي: ما رأيت أحداً من ناقصات، وقيل: يحتمل أن

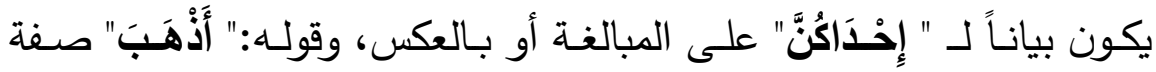

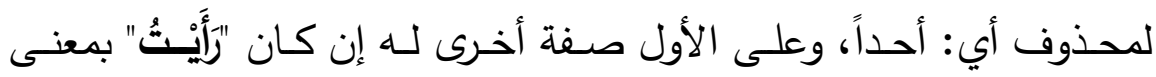

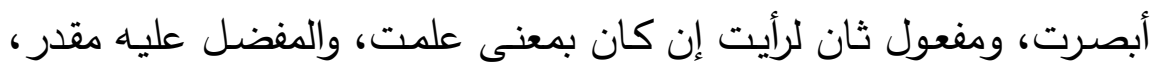
وهو أفعل التفضيل من الإذهاب؛ لمكان اللام في قوله: " للِبِّ الرَّجُجلِ" فمعناه: أكثر إذهاباً للب، والعقل غريزة يدرك بها المعنى، ويمنع عن القبائح، وهو نور الله في قلب المؤمن، واللب العقل الخالص من شوب الهوى وسمي بذلك لكونه خالص ما في الإنسان من قواه كاللباب من الثيء، وقيل: ما ذكا من العقل، فكل لب عقل ولا يعكس. و "الحَـازِمِ" الضــابط لأمـره من الحزم، وهو ضبط الرجل أمره وأخذه بالثقة، وهذه مبالغة في وصفهن بذلك؛ لأن الضابط لأمره إذا كان ينقاد لهن فغير الضابط أولى ، وفي ذكره مع ذكر اللبّ إشعار بأن فتتنهن عظيمة تذهب بعقول الحازمين، فما ظنك بغيرهم؟ وليس ذلك فيك ذماً لهن وإنما هو على معنى التعجب بأنهن مع اتصافهن بهذه الحالة يفعلن

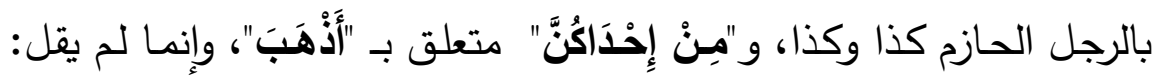

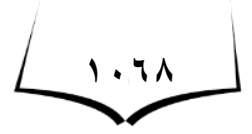


منكن؛ لأن الواحدة إذا كانت على هذه الصفة الذميمة فكونهن عليها أولى من غير عكس، وما أحسن قول جرير في وصف عيوبهن:

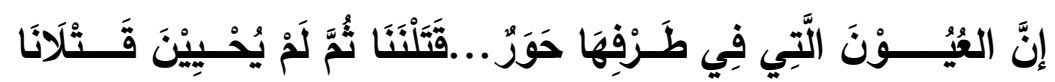

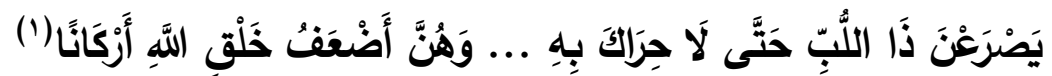
وليس المقصود هنا الانتقاص من قدر المرأة، بل سبق وصفهن بذلك للتعجب، وقد أشار إلى ذلك الإمام العيني بقوله: "فإن قلت أليس ذلك ذما لهن قلت لا وإنما هو على معنى التعجب بأنهن مع اتصـافهن بهذه الحالة يفعلن بالرجل الحازم كذا وكذا" (r) ولخفاء وجـه نقصـان دينهن وعقلهن كان استفهامهن: "وَمَا نُقْصَـانُ

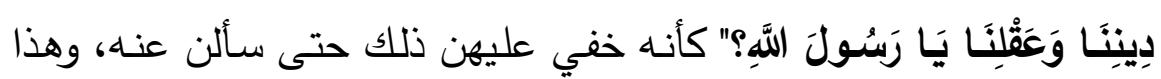
السؤال يدل على النقصـان - أيضـاً ؛ لأنهن إذا سلمن بما نسب إليهن من فئ الأمور الثلاثة: إكثار اللعن، وكفران العشير ، وإذهاب عقل الرجل ولَّه، ثم يسألن عن وجه كونهن ناقصات كان الاستفهام دالاً على النقصان. ولذا جاء جوابـه - صـلى الله عليـه وسـلم- لهـن بلطف وإرشـاد مـن غير تعنيف ولا

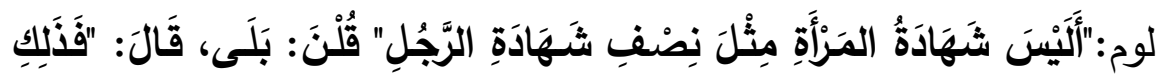

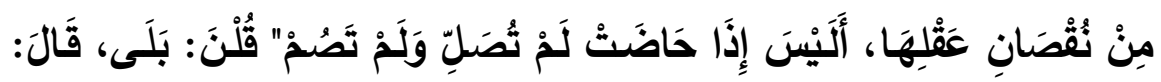

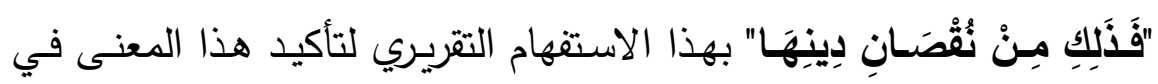
نفوسـن وبهذا الطباق بين الثـهادتين. وهذه ميزة التقرير بالاستقهام ففيـه انتزاع الإقرار من المخاطب، وإقرارُ المخاطب بمضمون الاستفهام - ثبوتًا أو بـان

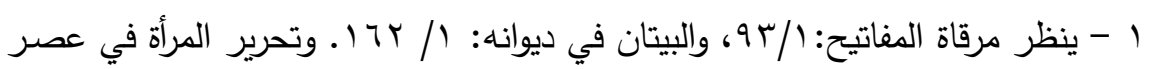

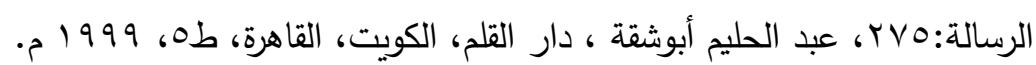

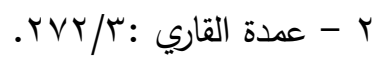

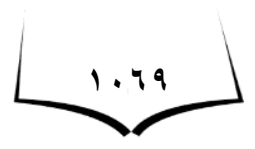


نفْيًا - آكدُ من ذِكْره بأسلوب الخبر ، وأسلوب الاستفهام يحقِق عنصر التفاعل بين المتكلم والمخاطب والخبر أو الرسالة المراد تبليغها للمخاطب، وهو مـا حدَث في حديث النبي -صلَّى الله عليه وسلَّم - والطَّريف أنَّ النسوة أجبن على كل استفهام ب"بَلَى" تقريرًا، والرسول لََ يكن يهرِف إلىى أنْ يُجبن؛ لأن ما اسنتَفهَههن عنه معلومُ لله - صلى الله عليه وسلم. وفي تعبيره بهذه العبارة ولم يقل:أليس شهادة المرأتين مثل شهادة الرجل؛ لأن في عبارته تلك تتصيصاً على النقص صريحاً بخلاف ما لو قال ذلك، فإنه يدل عليه ضمناً. وقد جاءت السنة لتقرر ما جاء بـه القرآن الكريم، حيث فصّل ذلك

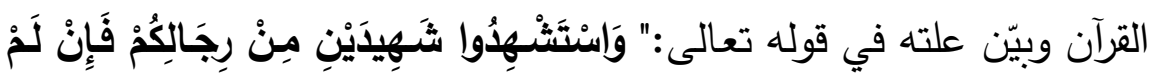

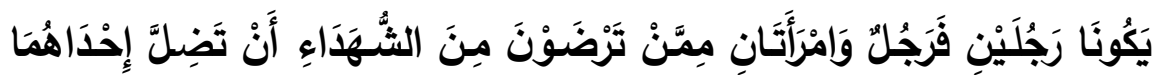

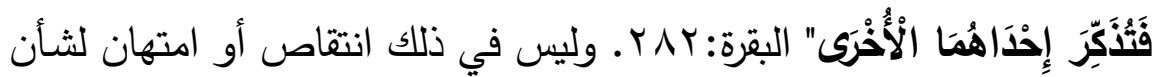
المـرأة، فهذا يرجـع إلى اختلاف طبيعـة المـرأة عـن الرجل، والحديث يعلل نقصان العقل عند النساء بكون شهادة امرأتين تعدل شهادة رجل، والعلة في

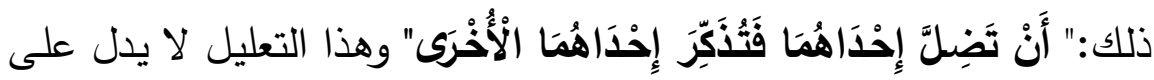
أي اختلاف بين الرجل والمرأة من حيث التفكير،كما لا تدل على اختلاف في قدرات الحواس والذكاء، بل تثير إلى الضـلال والتذكير ، وقد بيّن الطباق ذلك ووضحه وبينه.(1) والضلال هو العدول عن الطريق المستقيم والنسيان قد يؤدي إليه، والتذكير فيه لفت الانتباه، ويتأثر بالحالة النفسية، وقد تحجبه كلياً عن رؤيـة

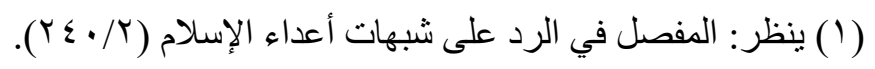


الحق والواقع، فالذي لا يرى إلا جانباً معيناً من الواقع ولا يرى غيره، يكون

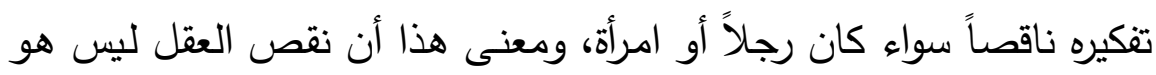
في قدرات التفكير، ولا في تركيبة الدماغ، وإنما في العوامل المؤثرة في

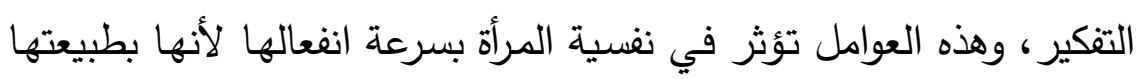
تتميز بالعاطفة، وتحكم على الأشياء متأثرة بعواطفها التي جبلت عليها؛ لأن عاطفتها أحياناً تغلب على عقلها، فالرجل يتغلب عقله على عاطفته، والمرأة تتغلب عاطفتها على عقلها، وهذا من حكمة الله عز وجلّ فلولا العاطفة القوية عند النساء لما عاش طفل ولا تربى وليد، وتربية الأطفال تحتاج إلى عاطفة قوية لا إلى فلسفة عقلية، والشريعة الإسـلامية اتَّجهت إلى تعزيز الثهادة؛

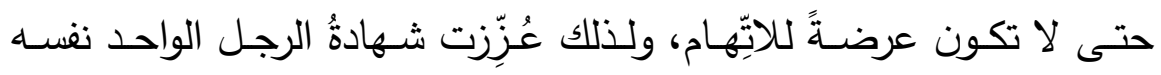
بشهادة رجل آخـر، ولم يُعد ذلك ماسَّا بكرامـة الرجل مـا دام ذلك التعزيـز أضمنَ لحقوق الإنسان، وبناء عليه فإذا لم يكن هناك إلا شـاهد من الرجال واحتيج في الثِّهادة إلى المرأة، كان تعزيزُ شهادة المرأة بشهادة امرأة ثانيـة فئه جاريًا على نَفْس الأصل الذي يجري على تعزيز شهادة الرَّجل الواحد بشهادة رجل آخَرَ • وأيضًا فالثهادة جاءتُ في مقام الاستيثاق في القضــايا المدنيَّة والتجارية، والرجل أقدر على أداء الثهادة من المرأة. (')

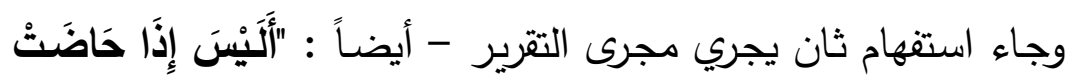

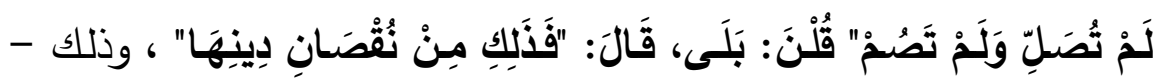

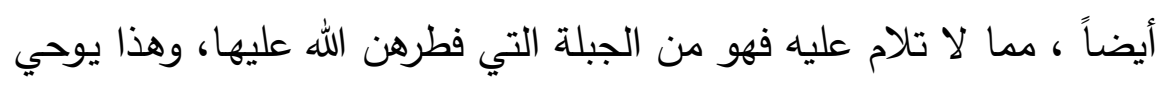

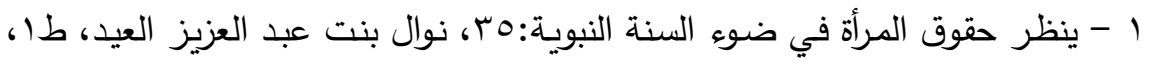

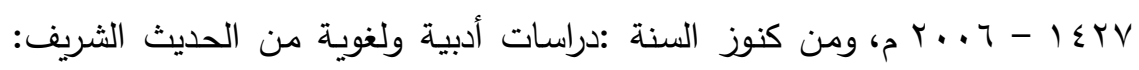
10V

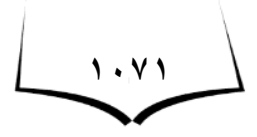


بأن من كثرت عباداته وصلاته وصيامه زاد إيمانه ودينه، ومن قلت عباداته

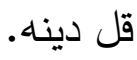

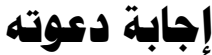

رُوِيَّ عَنْ أَبِي هُرَبْرَةَ - رَضِسيَ المَّهُ عَنْهُ - قَالَ: قَالَ رَسُولُ - اللَّهِ

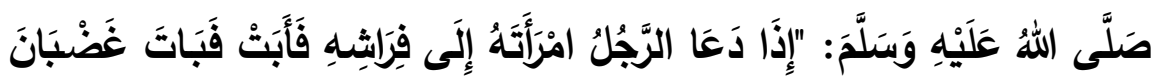

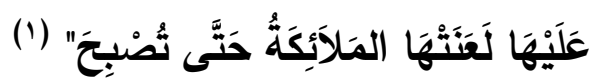
من نعم الله تعالى التي لا تحصسى أنسه خلق في داخل الرجل قوة

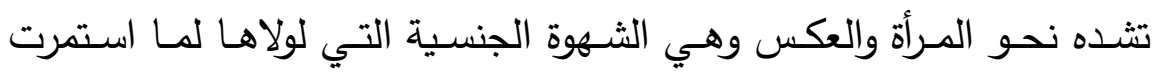
البشرية، إلا أنّ هذه الشهوة وإن كانت مصدر خير على الإنسان، فإنّ لها قابلية أن تتحوَّل إلى نقطة ضعف تبعده عن الاستقامة في مسيرته، لذا جاء الشرع الحنيف كي يهذبها لتبقى في دائرة الخير والصـلاح وذلك من خلال تلبية هذه الغريزة عبر بوابة واحدة هي الزواج. وفي هذا الحديث تحذير من

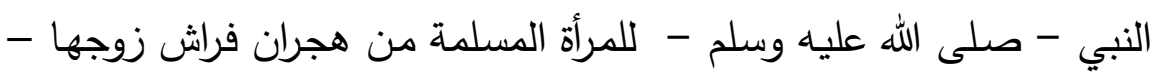
فمن حقه عليها طاعته في الفراش - وذلك حتى تتجنب عذاب الله واللعن من الملائكة فمغبة هذا اللعن هو الطرد من رحمة الله.. فهذا الحديث خبر مراد به الوعيد الثديد للزوجات المتمنعات على

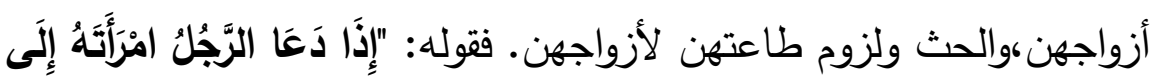

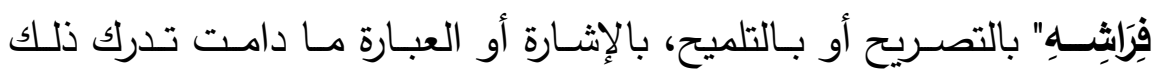
وتقهمه، وفي حذف أداة الدعوة دلالة على عمومها وشمولها كل ما تفهم منـه الزوجة وتعي مراد زوجها.

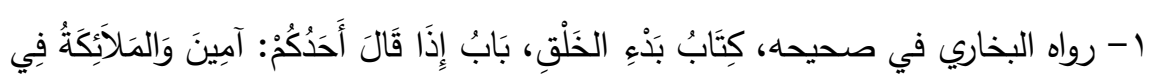

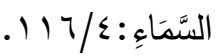

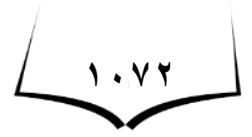




\section{مجلة قطاع كليات اللفة العريبية والشعب المناظرة لها العكذ[ب]}

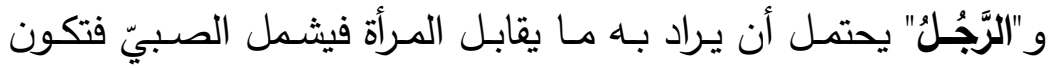

إجابته واجبة على زوجته المكلفة، وعلى وليّ غير المكلفة أمرها بذلك وهو

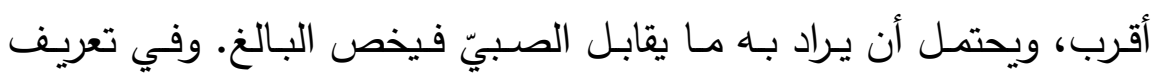
(امـرأة) بالإضـافة إلى ضـــيره إثـارة إلى اختصـاصــه بهـا، فهـي المـأمورة بطاعته والاستجابة لاعوته لا غيره.

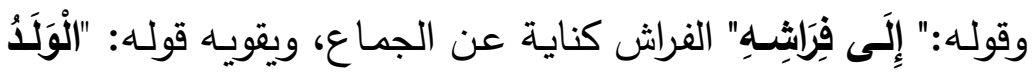
لِلْفِرَاشِ"( ) أي لمن يطأ في الفراش، أي لمالك الفراش وهو الزوج والمولى. فلا حَظَّ للزاني في الولا وإنما هو لصـاحب الفراش، والمرأة تسمى فراشاً لأن الرجل يفترشها، ولكن المراد بالقراش في هذا الحديث الكنايـة عن الجماع، فسياق الحديث يدل على ذلك ويؤكده. والتعبير بالكناية دون اللفظ الصريح فيه تهذيب لا تتفر منـه الأذواق السليمة، والكناية عن الجماع وعن الأشياء التي يستحى منهـا كثيرة الورود في القرآن والسـنة، فـالقرآن قد يعبّر عنـه بالملامسـة والمسّ والغشـيان والتقرب والإفضـاء والدخول والإتيان والمباشـرة والرفث وغير ذلك.. وكذا في السنة النبوية حيث عبّر عنه بالإتيان والمواقعة والحاجة والإفضـاء والمباشرة والمسّ والطواف والمبيت والرفث وغير ذلك .. مما يدل على مدى تأثر الكنايات النبوية بالكنايات القرآنية في ألفاظها وحسن تصويرها وقوة تأثيرها، فالسنة بيان للقرآن.

وفي هذه الكناية إيماء إلى جواز تعدد الفراش، وإيماء إلى التستر حالة

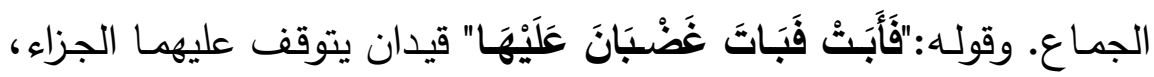
فبهذه الزيادة يتجه وقوع اللعن؛ لأنها حينئذ يتحقق ثبوت معصيتها، بخلاف

1- رواه أحمد في مسنده عَنْ عُمَرَ بْنِ الْخَطَّابِ - رضي الله عنه: ا/v •r. 
ما إذا لم يغضب من ذلك فإنه يكون إما لأنها عذرها وإما لأنها ترك حقه من ذلك. (1)

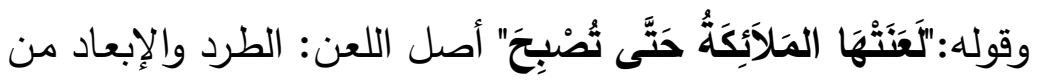

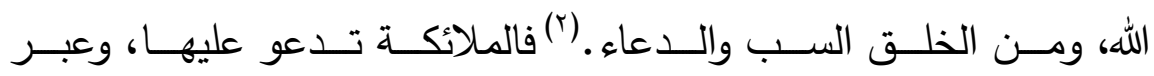
بالماضـي"لَعََتْهَها" عن المضـارع "تلعنها" لتحقق اللعن ودعوة الملائكة عليها جزاء عصيانها أمر زوجها، وفي ذلك مزيد من التهويل والتخويف والتحذير .

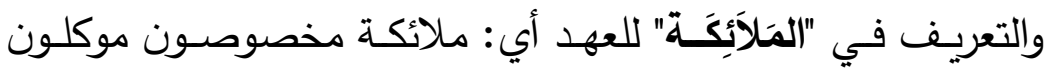
بذلك، ويحتمل أن يكون للجنس أي: عموم الملائكة. وفي ذلك مزيد تهويل

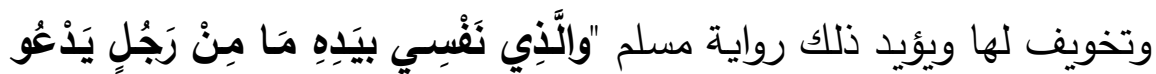

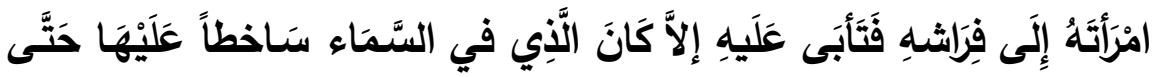

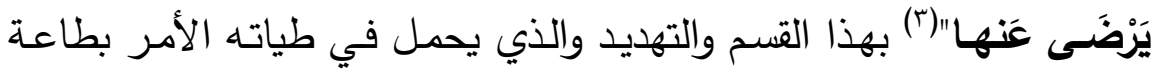
الزوج والنهي عن عصيانه، فالله سبحانه يسخط عليها حتى يرضسى عنها زوجها. وفي عدم ذكر المبيت فيها دلالـة على استواء الليل والنهار في وجوب الطاعـة وفي تحقق اللعن إذا أبـت في أحدهما، فقولـه: "التَّذِي في السَّمَاء" إن كان المراد منه ساكنها فهو الملائكة، وإن أريد بـه الحق سبحانه

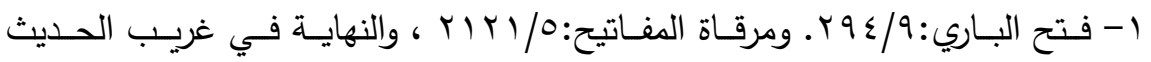

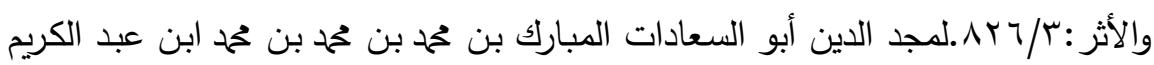

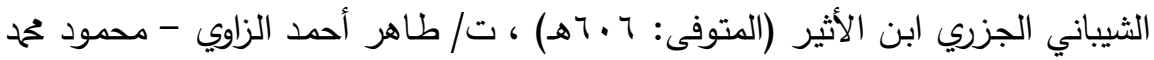

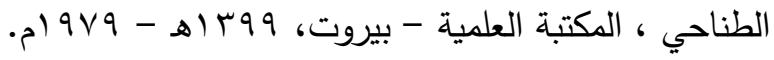

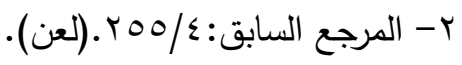

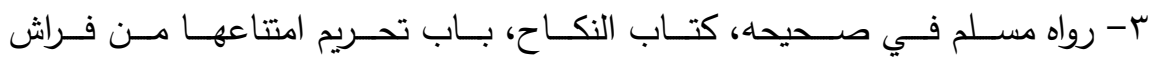

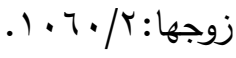

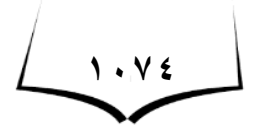




\section{مجلة قطاع كليات اللفة العربية والشعب المناظرة لها العكد [r]]}

فيؤول بأن المـراد الذي سلطانه أو ملكوتـه أو أمـره في السـماء، لاستحالة

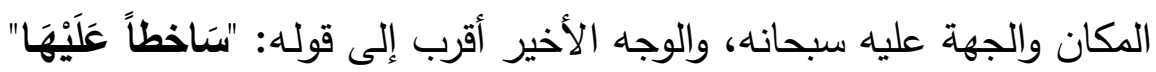
وإن صـح على الأول إفراده بحسب لفظ "الَّذِي" المـراد منـه النوع الذي هو

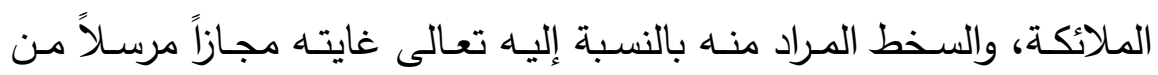

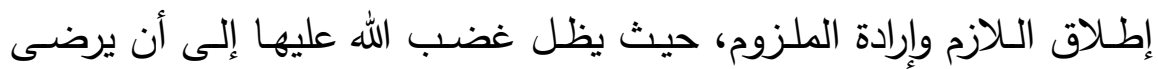

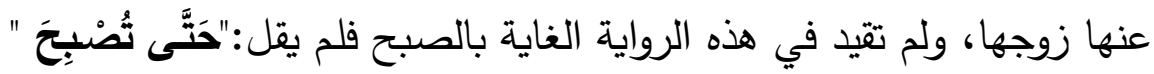

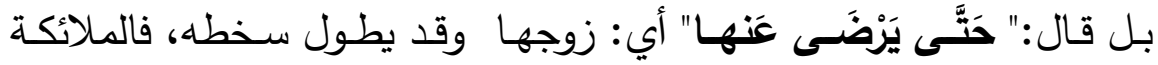
تلعنها حتى تصبح، والله -عز وجل- يسخط عليها حتى يرضسى عنها هذا الزوج، وهذا يدل على شدة وعظم حق الزوج على المرأة، ولذا يقول الطيبي -

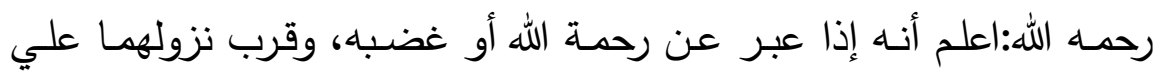
الخلق، خصّ السماء بالذكر، وقد جمع بينهما في قوله تعالي: "وفِي السَّمَاءِ

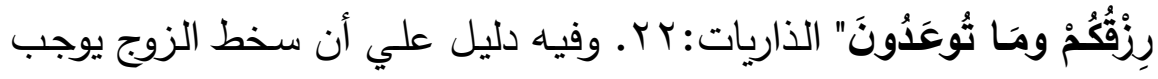
سخط الرب، ورضاه يوجب رضاه، هذا في قضاء الثهوة، فكيف إذا كان في أهـر الدين؟!وظاهر الحديث اختصـاص اللعن بــا إذا وقـع منهـا ذلك ليلاً لقوله:" حَتَّى تُصْبِِحَ " وكأنَّ السر تأكد ذلك الثَأن في الليل وقوة الباعث عليه، ولا يلزم من ذلك أنه يجوز لها الامتناع في النهار ، وإنما خصّ الليل

بالذكر لأنه المظنة لذلك. (') بله دله<smiles>[CH]</smiles>

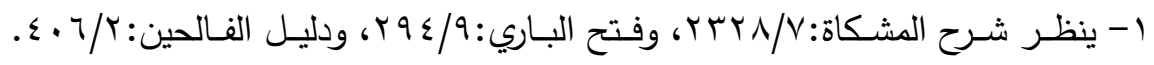

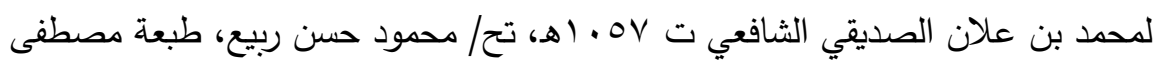

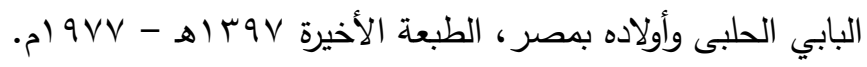




\section{الاستمتاع بها حال هيضها}

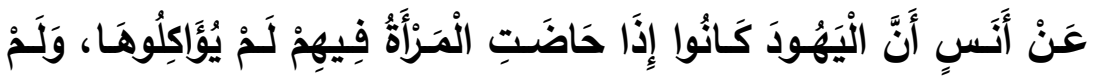

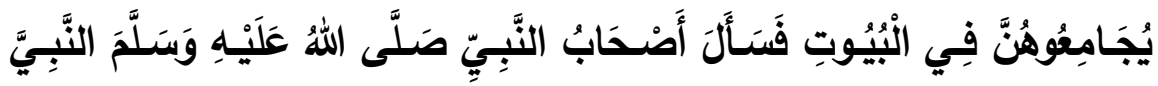

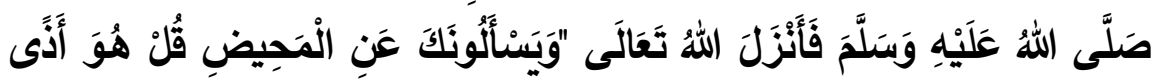

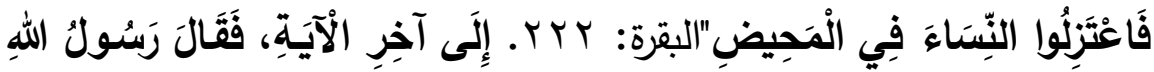

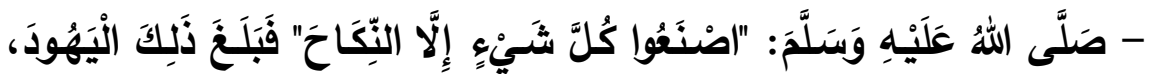

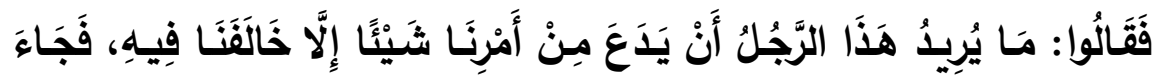

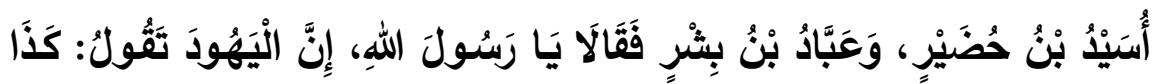

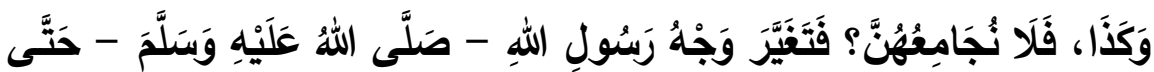

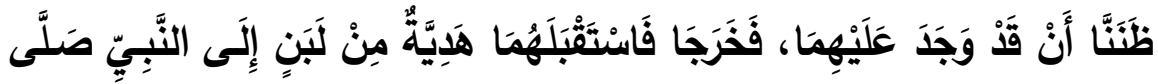

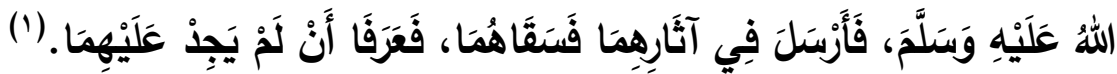

هذا الحديث فيه بيان ما كان عليه اليهود من التشدد، ومن مجانبة النساء في حال الحيض، والابتعاد عنكن، ويقابلهم النصارى الذين يجامعوهن

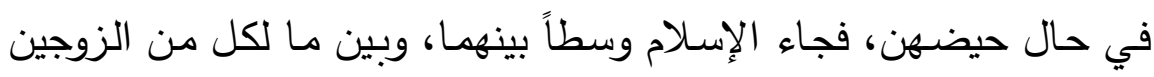

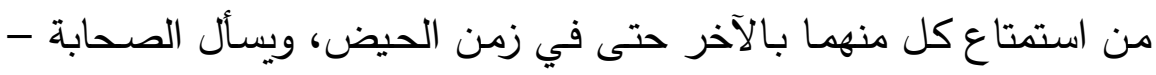

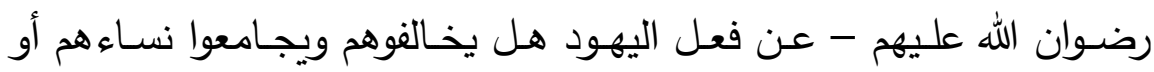

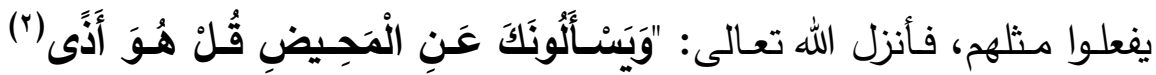

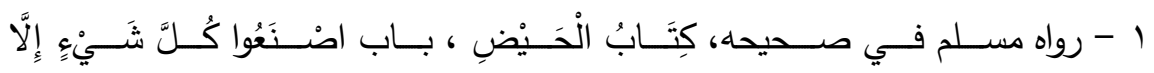

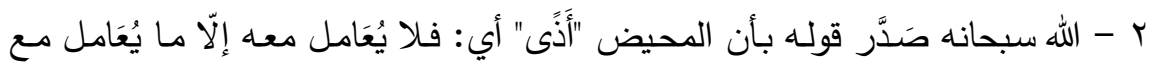
الأذى، وهو الاجتتاب والاعتزال عنه فقط، لا كما كان اليهود يفعلونه من المتاركة مطلقيًا،

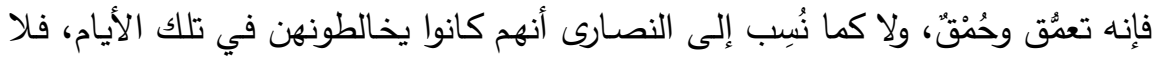

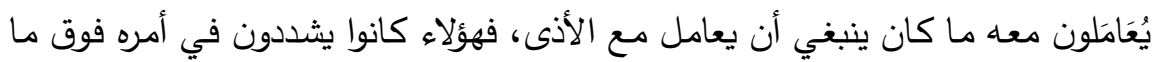
$==$ 


\section{مجلة قطاع كليات اللفة العربية والشعب المناظرة لها العكد [r]]}

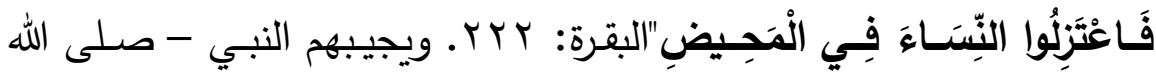

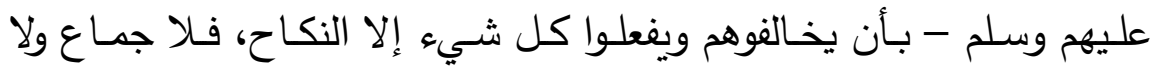
اعتزال ومجانبـة ومباعدة ومفارقة، وإنمـا اجتمـاع واختلاط ومؤاكلة ومشـاربة ومؤانسة إلا النكاح. وقد صور البيان النبوي ذلك بصور بديعة منها:

أراده الثـارع، وهؤلاء كـانوا يستخِفُون بمـا أمرهم الله سبحانه، فكأنهم كانوا على طرفي

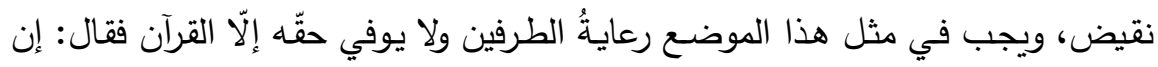

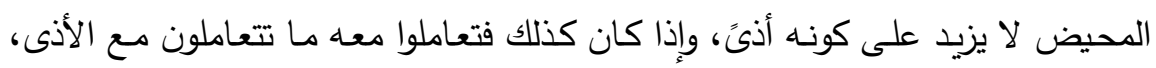

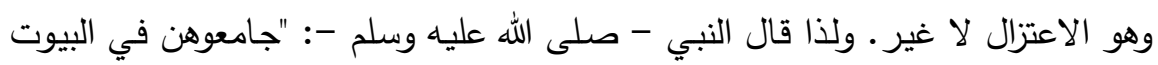

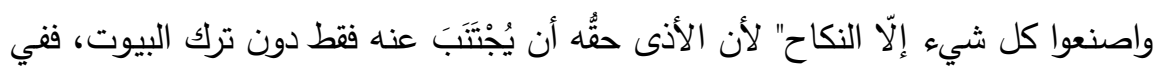

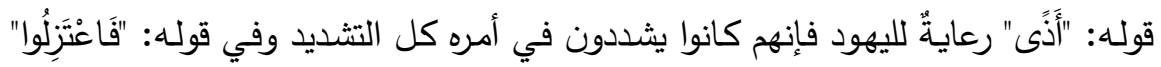

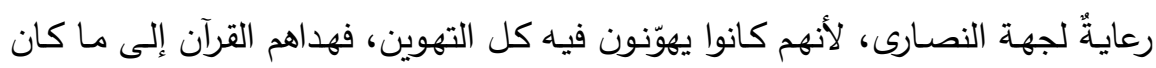

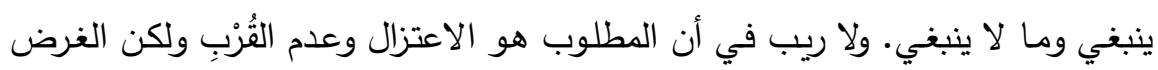

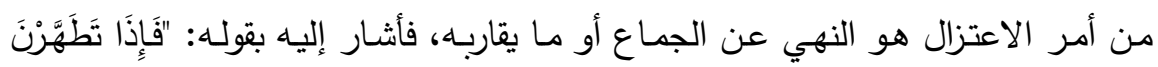

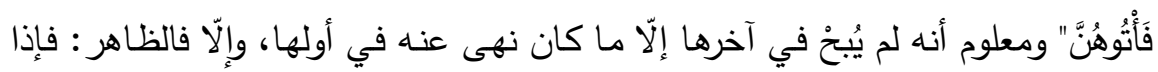

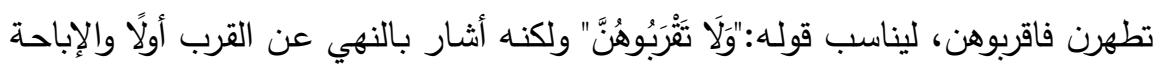

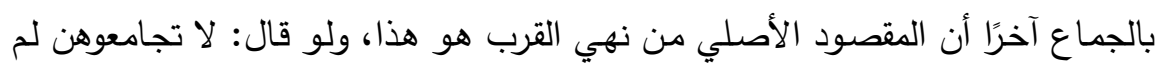

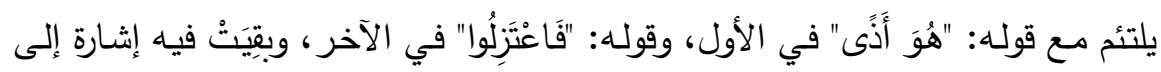

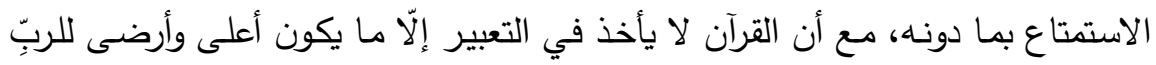

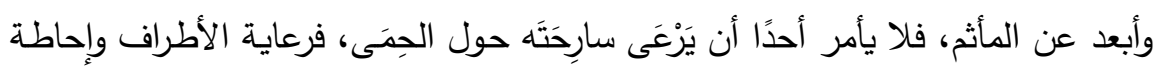

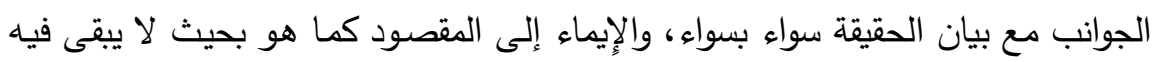

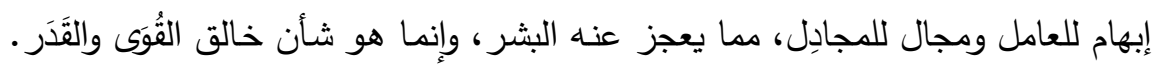

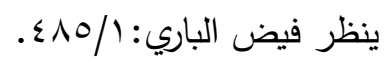




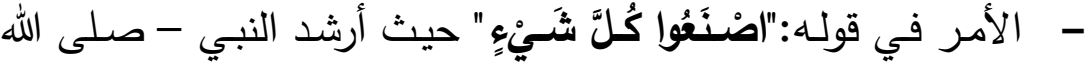

عليه وسلم - إلى مخالطة النساء وعدم مفارقتهن، وجاء مفسراً ومبيناً لقوله الهاء

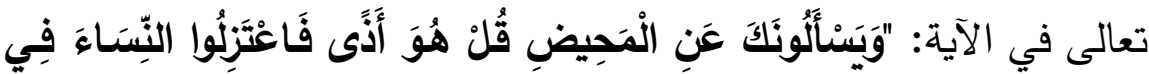
الْمَحِيضِ" فإن الاعتزال شامل للمجانبة عن المؤاكلة والمصـاحبة والمجامعة،

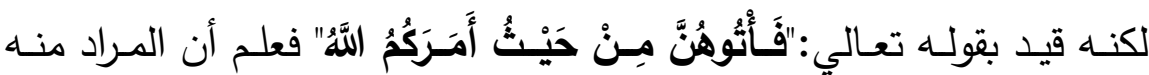

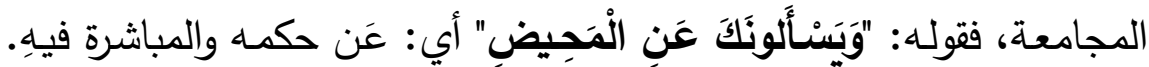
ففيها إيجاز بحذف المضـاف، وقوله:"أَذنىً" فسر بالدم النجس وبما فيه من القذر والنتن وخروجه مِن مخرج البول، وكل ذلك يؤذي. والتتكير هنا للقلة

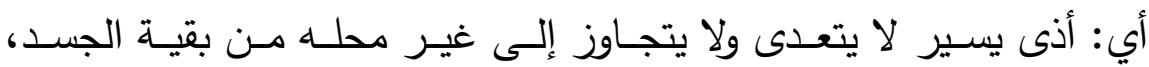
والتعبير بالمصدر" أذى" يشير إلى إبطال ما كان من التغليظ في شأنه وشأن المـرأة الحسائض في الشـرائع السـابقة، وذلك بلفظ رقيتق مهذب يجنـح إلى التصـوير والتلميح دون التصـريح، وقالَ الخطابي: الأذى هو المكروه الذِي

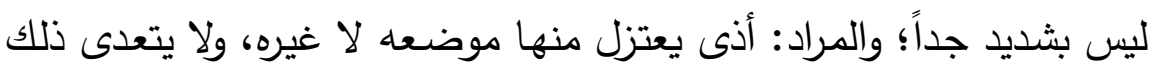
إلى سائر بدنها، فلا يجتنبن ولا يخرجن مِن البيوت، حيث يتأذى معه الزوج من مجامعتها فقط دون المواكلة والمجالسة، فقدروي: أنّ أهل الجاهلية كانوا إذا حاضت المرأة لم يؤاكلوها، ولم يشاربوها، ولم يجالسوها على فرش، ولم يساكنوها في بيت، كفعل اليهود والمجوس، فلما نزلت أخذ المسلمون بظاهر اعتزالهنّ؛ فأخرجوهنّ من بيوتهج، فقال ناس من الأعراب: يا رسول اللَّ، البرد شديد، والثياب قليلة، فإن آثرناهن بالثياب هلك سائر أهل البيت، وإن استأثرنا

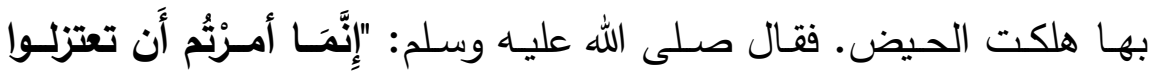

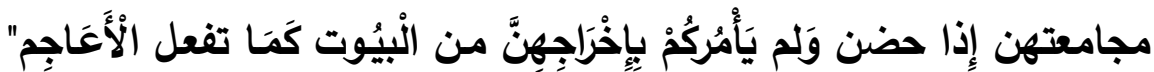
فالمراد: أن الأذى بهن لا يبلغ الحد الذي يجاوزونـه إليه، وإنما يجتنب منهن

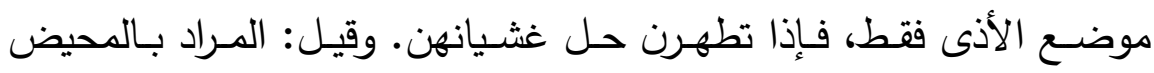

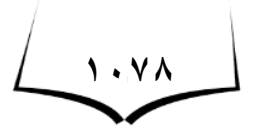




\section{مجلة قطاع كليات اللفة العربية والشعب المناظرة لها العكد [r]]}

هاهنا: مكان الحيض، وهو الفرج. فقال - صلى الله عليه وسلم: "اصْنَعُوا كُلَّ شَيٍِْ إِلَّا النِّكَاحَ" أي: الجماع، إطلاقاً لاسم السبب علي المسبب؛ لأن عقد أند

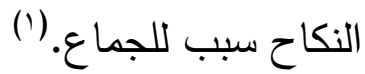
- - التعبير بـ "اصْنَعُوا" دون افعلوا مثلاً ، وكأن النبي -صلى الله عليه وسلم - يهمس في أذن الرجال لإظهار الرغبة في المرأة حتى وهي في هذه الحالة، فإنهن يعجبن بذلك، فبعض الرجال قد يأنف من المرأة ويبتعد عنها وهي في هذه الحالة فتكابد عناء فوق عناء الحيض حين تظهر أنها غير مرغوب فيها وهي بتلك الحالـة، حيث الثـور بالانزعـاج النفسي وضسيق الصدر ، وهبوط عام في القوى وثقل بالحركة والضجر ، ويظهر عند بعضهن اضطراب حاد في المزاج ، وزيـادة في الحساسية وسرعة الانتقال من موقف إلى آخر دون تبصر أو روية، فتغضب المرأة لأتفه الأسباب ولا تطيق حتى أقرب المقربين،وعلى الزوج في هذه الحالة عدم إظهار الدهشة تجاه تقلبات عادات زوجته في هذه الفترة، وإظهار خطأ سلوكها وغرابة تصرفاتها، فذلك هذه يزيـــ مـن حدة شعورها بالدونيـة، ويوجـه النبـي - صـلى الله عليـه وسـلم -

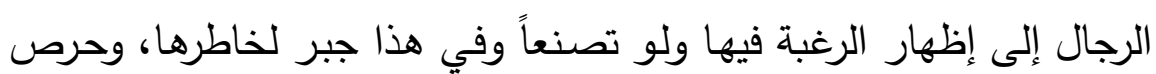
نبوي على إثاعة روح الألفة والمحبة بين الزوجين.

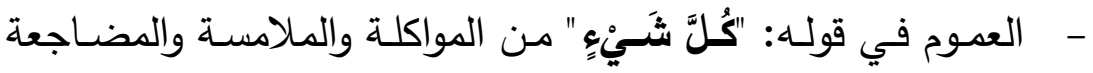
وغير ذلك، وهذا أسلوب نبوي راق فضـلاً عما فيـه من عموم ففيه تهذيب مون ورقي في التعبير •ولم يرد بذلك بيانُ كلِّ ما يجوز لله من امرأته، ولكنه أراد

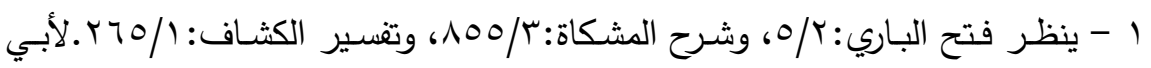

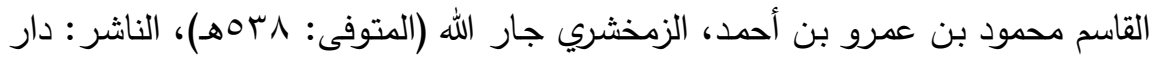

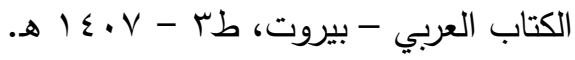


-والله تعالى أعلم- مخالفة اليهود، فشدد في التعبير فقط. وفهمه الصحابة رضي الله عنهم - حقًا، ولذا قالوا: "فَلَا نُجَامِعُهُنَّ؟؟، وقد اختُلف في مراده، وفي طريق: "أفلا نتكحهن؟، فمَنْ حمله على المجامعة في البيوت فلعله غَفَلَ عن هذا اللفظ، وإنما تبادروا إلى الإذن بالمجامعة، لأنهم فهموا أن القرآن نزل

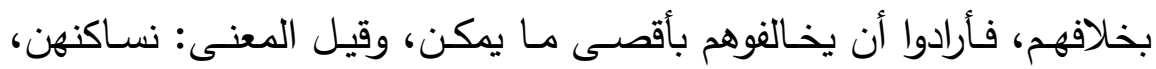

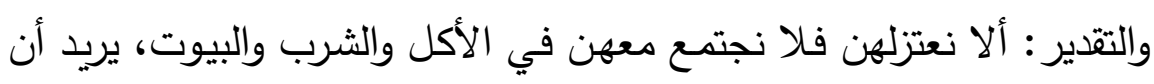

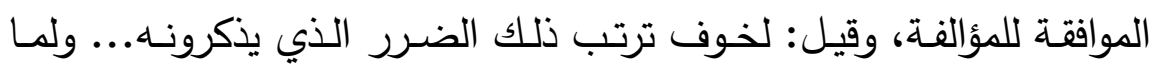

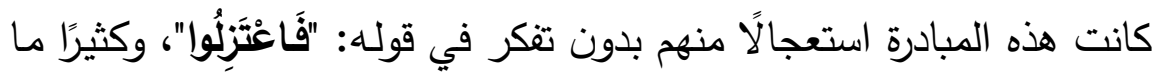
يعتري المرء عند الاستعجال في الامتثال - غضبَ عليهم النبي - صلى الله عليه وسلم - فإِن طريق النبوة بين الإفراط والتفريط، والعدل في الرضـا، والغضب والصدق في الجد والهزل.وتغير وجها رسول الله - صلى الله عليه

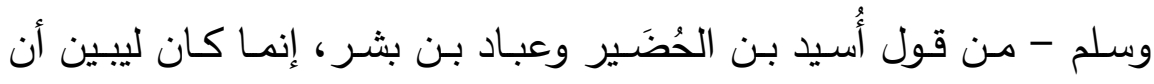

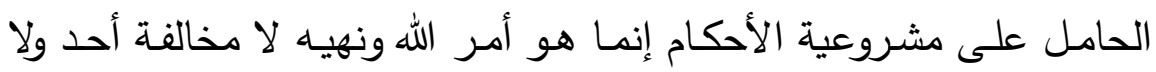
موافقته كما ظنا، ثم لما خرجا من عنده وتركاه على تلك الحالة خاف عليهما

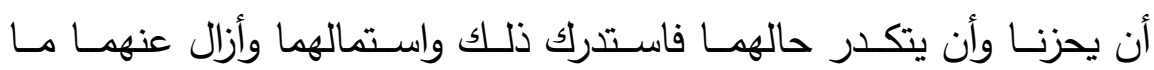
أصابهما؛ بأن أرسل إليهما فسقاهما اللبن رأفة ورحمة منه لهما على مقتضى

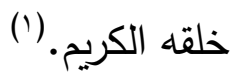

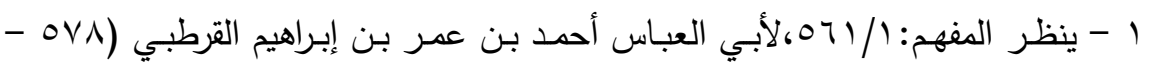

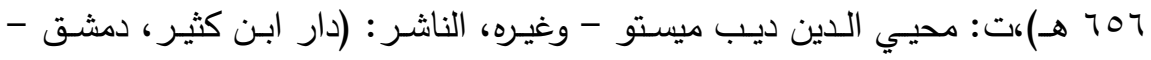

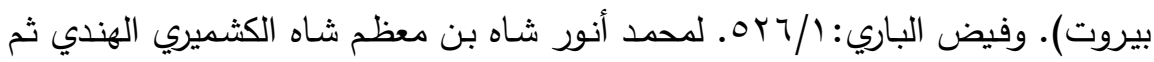

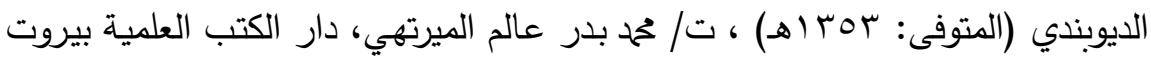

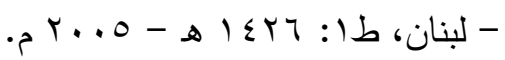




\section{طاعته في غير معصية.}

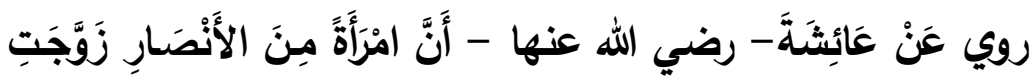

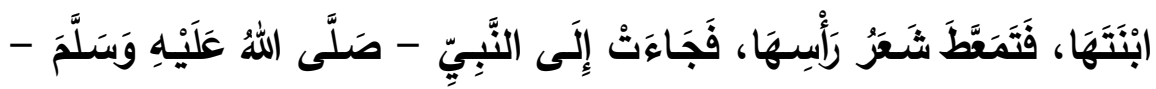

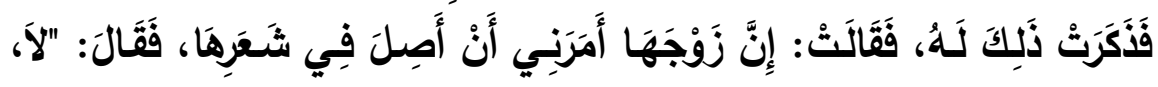

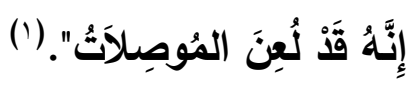

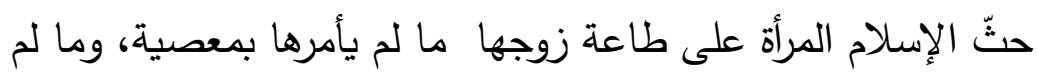

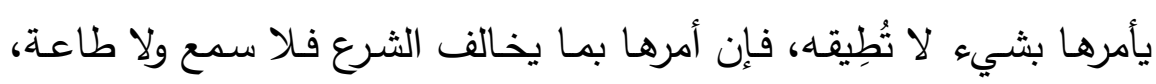

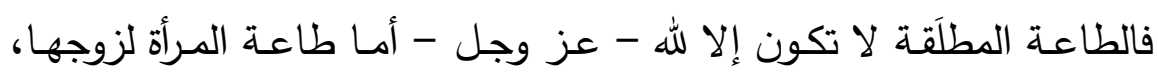

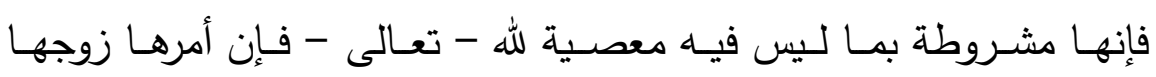

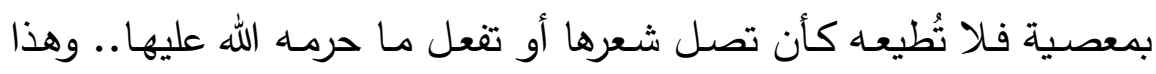

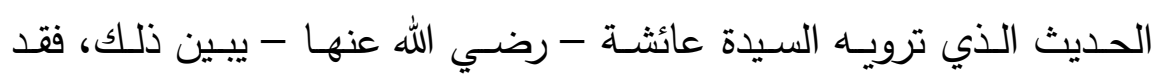

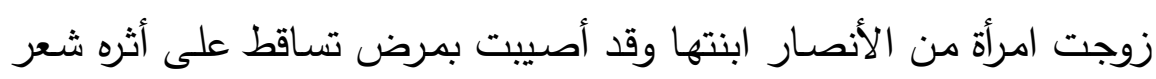

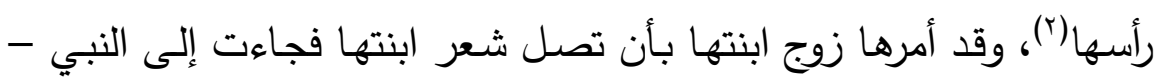

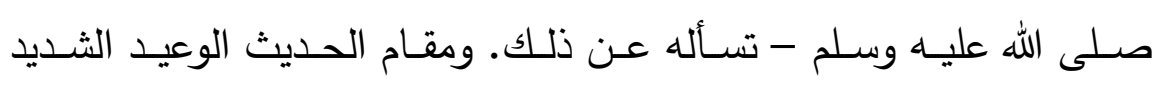

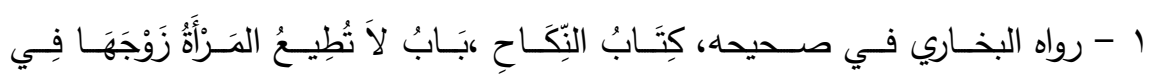

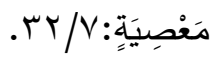

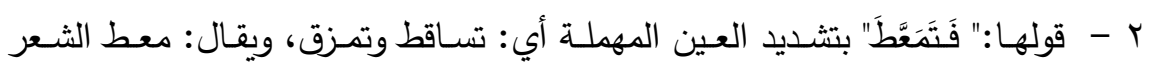

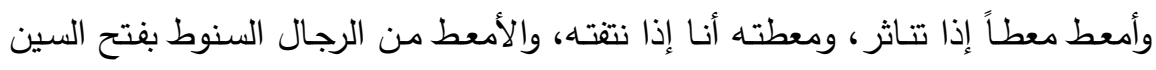

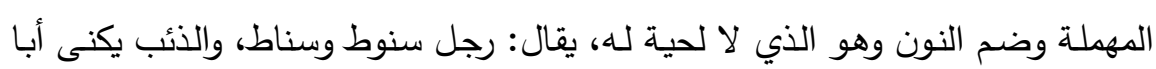

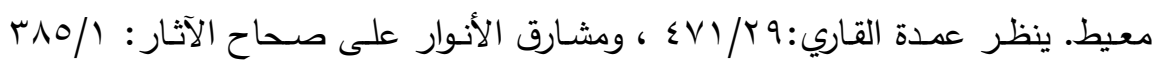

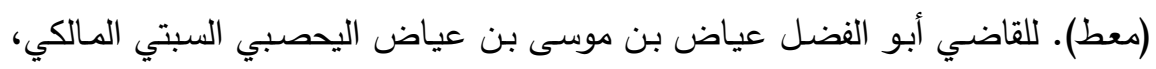
دار النشر : المكتبة العتيقة ودار التزاث.

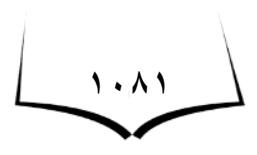


والترهيب من وصل شعر الآدمي بمثله وقد اتسم نظم التراكيب في الحديث بخصائص وفّت بالغرض منها، وتجلى ذلك في أسلوب بناء الحديث، فهو أسلوب خبري موجز ، وقد لفت ابن وهب إلى هذه الغايـة في حديثه عن المواضع التي يحسن فيها الإيجاز ، إذ جاء منها: " المواعظ والسنن والوصسايا التي يُراد حفظها ونقلها، ولذلك لا ترى في الحديث عن رسول الله

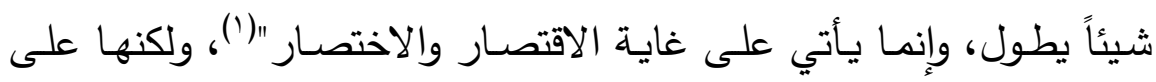
الرغم من وجازتها إلا أنها قامت بأداء المعنى على خير وجه.

ففي قوله:"لا" إيجاز بالحذف للعلم به من السؤال، أي: لا تَسِلي في شعرها، كمـا أنّ هذا الحذف يوحي بغضسبه - صـلى الله عليه وسلم -

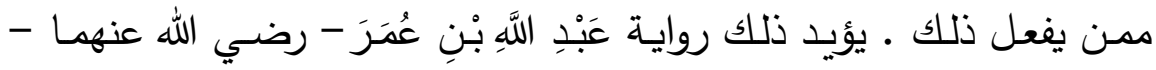

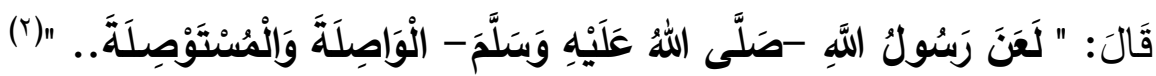

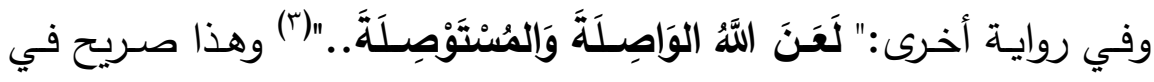
حكاية ذلك عن الله - عز وجل - إن كان خبراً، ويحتمل أنه دعاء منـه صلى الله عليه وسلم- على من فعل ذلك. وجاء هذا النهي معللاً بقوله:" إِنَّهُ قَّْ لُعِنَ المُوصِلاَتُ" أي: لعن الله من يصلن شعورهن واللاتي تقدن بالوصل. وأكد هذا الخبر بأكثر من مؤكد بـ "إِنَّ"، وضمير الثأن، و "قَّْ" لتحذير من يفعل ذلك، وبيان سوء عاقبته.

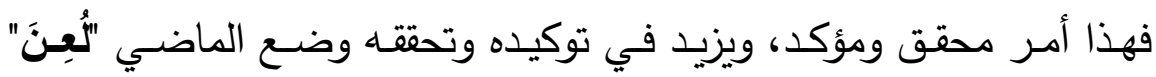

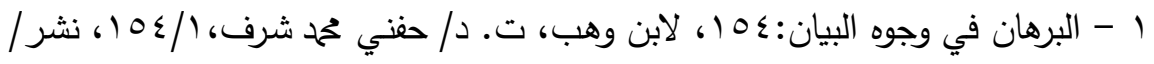

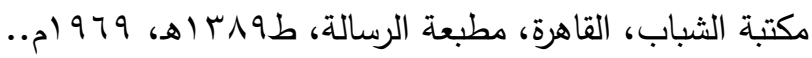
r

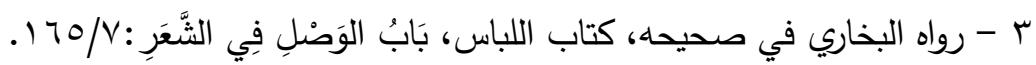

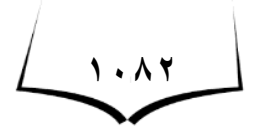




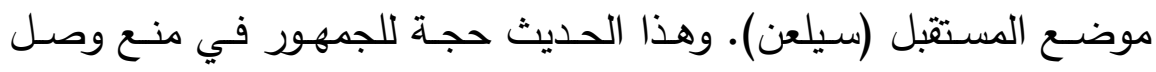

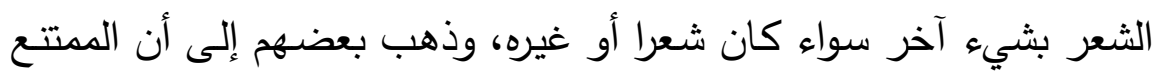

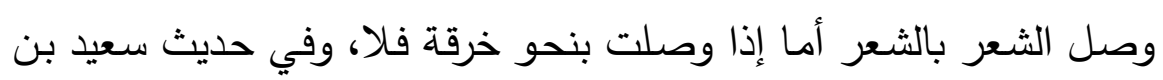

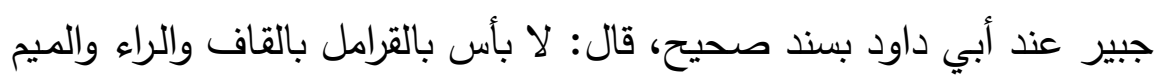

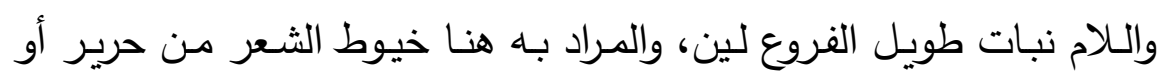

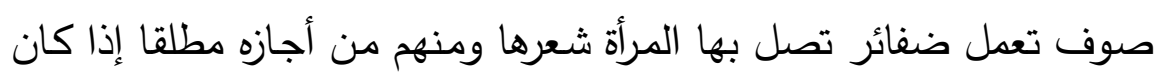
بعلم الزوج وإذنه لكن حديث الباب حجة عليهم. (') ولمزيـــ من الترهيب جـاء بنـاء الفعل للمجهول في قولـه:" لُعِنَ" للعلم

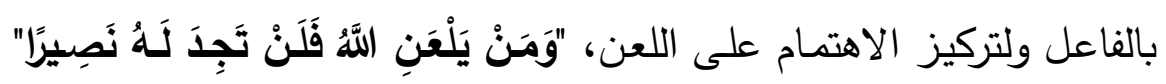

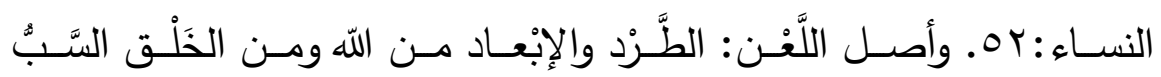
والدّدعاء. (r)

كما أن في تقديم المسند إليه (الضمير في إنها) على خبره الفعلي (قَّْ

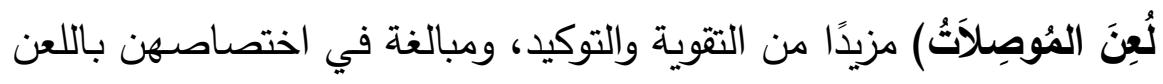
والطرد من رحمة الله تعالى. منئ.

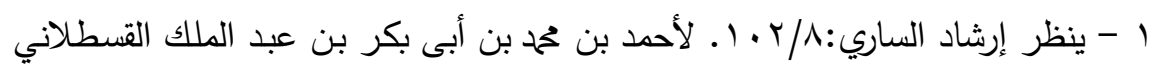

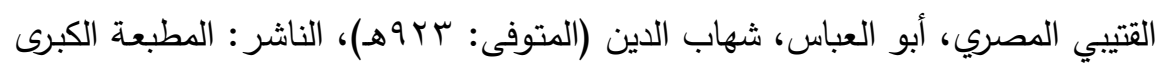

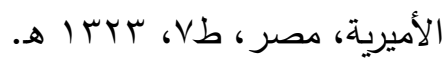

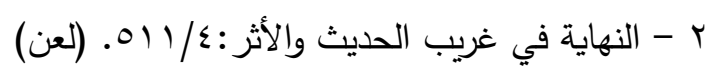

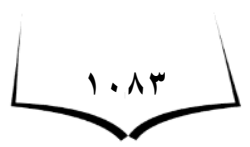




\section{المبحث الثاني: هق الرزوجة على زوجها}

لضمان حصول المودة والرحمـة وتحقق وجود السكينة بين الزوجين جعل الله لهذه العلاقة قانوناً يحكمها ، وفرض على كلٍ منهما حقوقاً يؤدِّيها للزوج الآخر ، ولا بـ لكل منهما أن يفي بحقوق الآخر، لتقوم حياة سعيدة قائمسة على التقوى والتعاون، وتدوم المحبَّة والألفة، وحُسن العِشـرة، وليدوم

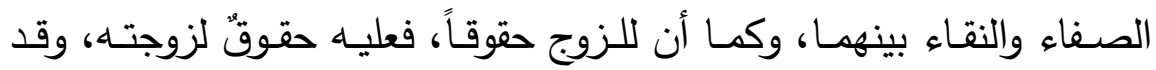
جاءت السنة النبوية وبينت ذلك وصورته أجمل تصوير ومن ذلك:

\section{هسن المعاشرة}

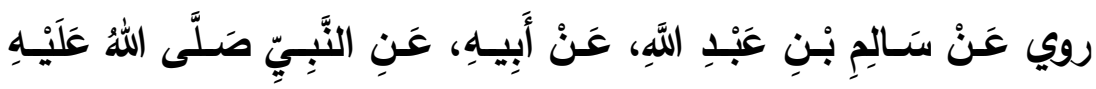

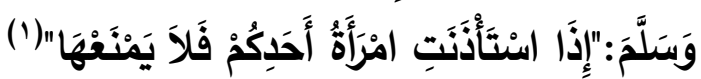

ورد هذا الحديث في مقام بيان طلب الإذن من الزوج والسماح به، فهو

من حسن المعاشرة بين الزوجين.

وأسلوب الحديث أسلوب خبري موجز، حيث بني على جملة واحدة

لا تصل إلى تمام معناها إلا بآخرها، حيث جاءت جملته شرطية، وجاءت أداة الشرط "إذا" لبيان غلبـة استتئذان المرأة زوجها، حيث تدل على أن من عاداتهم أن تستأذن المرأة من وليها للذهاب إلى المسجد. والتعريف بالإضـافة في قولهـ:"(مَرَأَةُ أَحَدِكُمْ" أفاد التخصيص فيحتمل

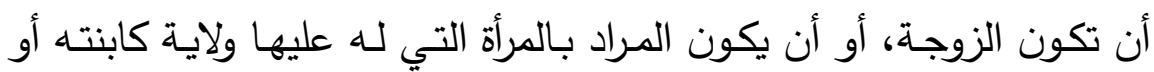

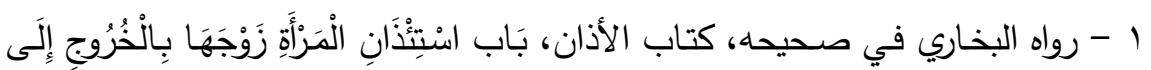

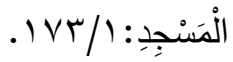


أمته وما أشبه ذلك. وهذا يومئ إلى أن الإنسان ليس لله أن يمنع امرأة غيره إلا إذا كانت له سلطة وولاية عليها.

وجاء قوله:" فَلاَ يَمْنَعُهَا " بضم العين وسكونها، فبالضم تكون خبراً مراداً به النهي حيث قام الخبر مقام الطلب لإظهار الحرص على وقوعه، وحمل المخاطب عليه أبلـغ حمل بألطف وجـه. وذلك مما يكون لـه عظيم الأثر على البيت المسلم، وتقويته وتوطيد العلاقة بين أفراده.

وعلى الجزم نهي مراد بـه إرشاد وتوجيه أمته إلى مـا فيه خير لهم في

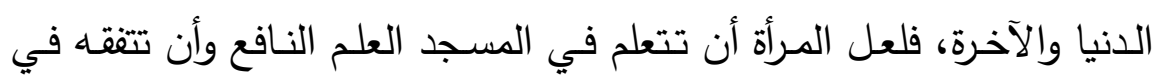
أمور دينها. ولذا فقد ورد رواية أخرى مقيدة، فقد روي من طريق آخر :"إذَّا

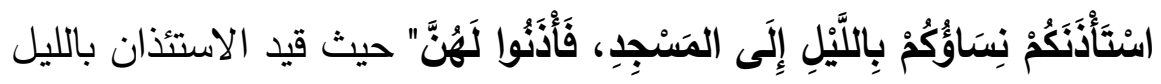
وإلى المسجد لأن الليل ستر لهن فاحتمال الفتنة فيه أقل، وذلك كله إذا أمنت

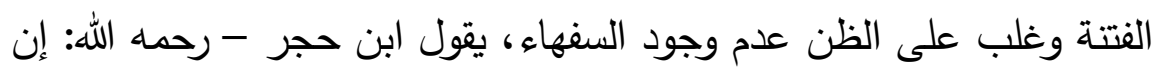
منع الرجال نساءهم أمر مقرر وإنما علق الحكم بالمساجد لبيان محل الجواز

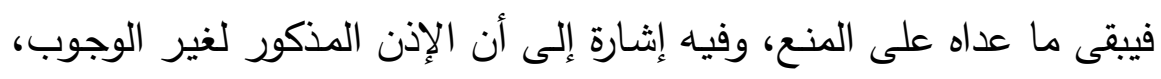

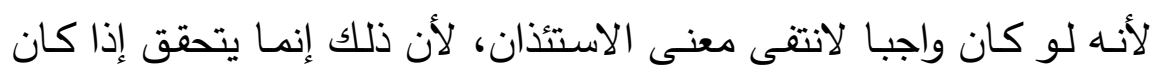

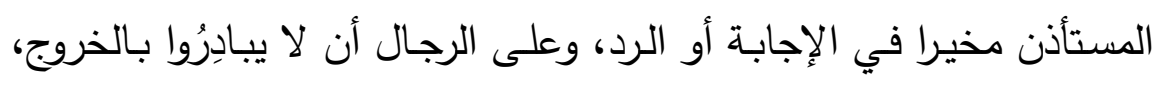
وعليهن أن يَتَسارَعْنَ إلى الخروجي، ولا يكثرن في مقامهن في المسجد، لئلا

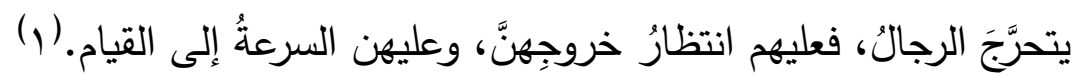
وهذه الرواية قيدت الرواية المطلقة التي معنا، أو أنه لما كان جائزاً على الإطلاق فالخروج إلى موضع العبادة بالطريق الأولى ولذا قال الإمام الطبري

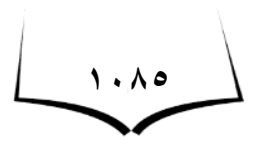


- رحمـه الله : في إطلاقه -عليه السـلام - لهن الخروج إلى المساجد وذلك إباحـة لا ندب ولا فرض ، دليل أن نظير ذلك الإذن لهن في كل مـا كان مطلقًا الخروج فيه نحو عيادة إحداهن بعض أهلها، وشهودها أعياد المسلمين

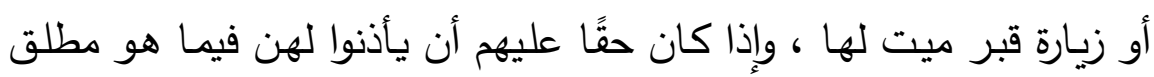
لهن الخروج فيه ، فالإذن لهن فيما هو فرض عليهن أو ندب الخروج إليه أولى ، كخروجهن لأداء شهادة لزمتهن ، أو لتعرف أسباب دينهن، ولأداء

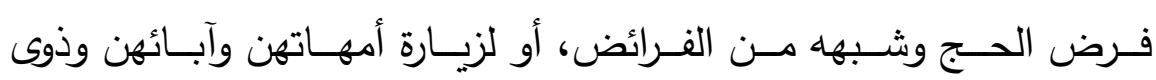

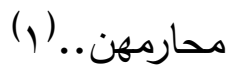

وقد بينت السنة النبويـة مفهوم المخالفة في قوله تعالى: "فِي بُيُوتٍ

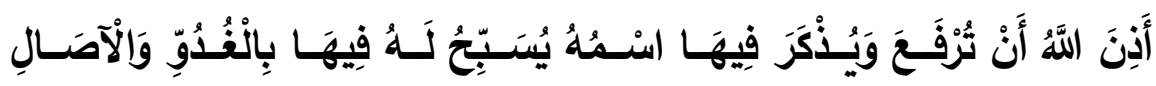

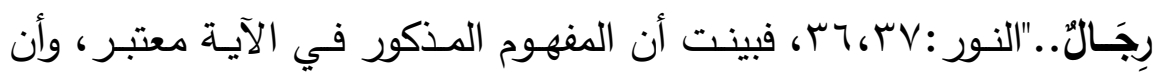
النساء لسن كالرجال في حكم الخروج إلى المساجد، وأوضـت أن صـلاتهن

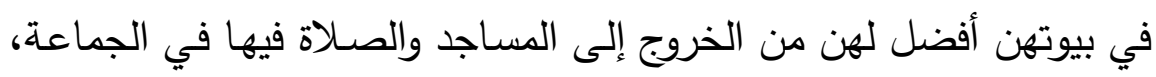

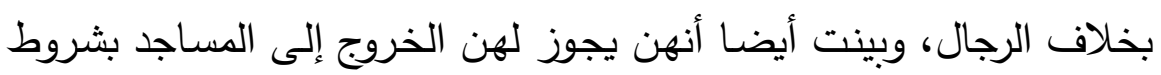

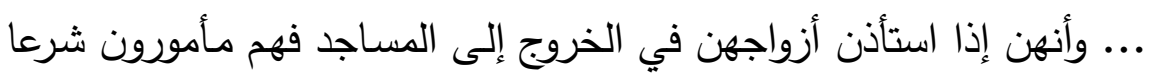
بالإذن لهن في ذلك مع التزامهن بالشروط المطلوبة. ولذا يشير الإمام النووي

1 - ينظر عمدة القاري:10/9؛، لأبي محم محمود بن أحمد بن موسى بن أحمد بن

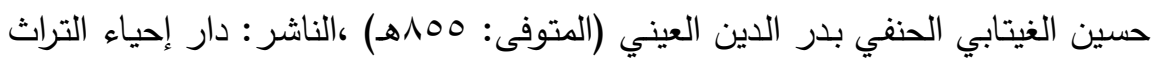

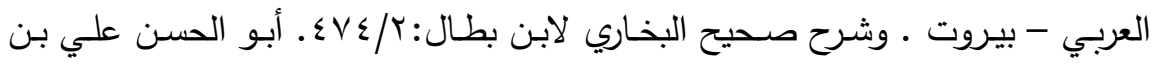
خلف بن عبد الملك (المتوفى: 9 ؟ §ه)، ت: أبو تميم ياسر بن إبراهيم، دار النشر : مكتبة

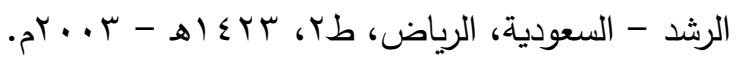




\section{مجلة قطاع كليات اللفة العربية والشعب المناظرة لها العكد [r]]}

إلى ما ورد في الحديث من الإذن لهن بقوله: وهو صحيح وعوملن معاملة

الذكور لطلبهن الخروج إلى مجلس الذكور • والله أعلم. (')

كما أن عدم تقييد الإذن في الحديث بالمساجد ليعم كل مباح لهن،

فلهن الخروج لزيـارة أهل وأقارب وعيادة مريض وللتسوق وغير ذلك مـا لم

ينهين عن ذلك. ولعل هذا أبلـخ رد على مـن يرمون الإسـلام بظلم المـرأة

وسلبها حقوقها وحريتها، فالنبي - صلى الله عليه وسلم - هنا ينهى الرجال

عن عدم الإذن لهن في فعل هذه المباحـات وغيرهـا، وفي الوقت نفسـه لا

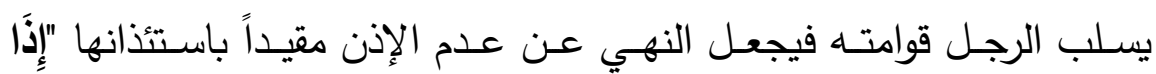

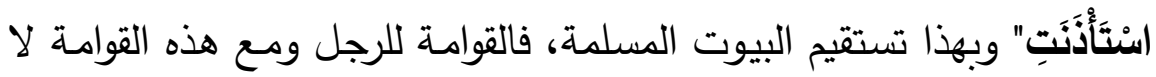
يكون التسلط المطلق، وكأني بهذا الحديث يهمس في أذن الزوج دون أن يضعف من قوامته، أو ينتقص منها، ويجبر بخاطر المرأة حين ينهى الرجل عن عدم الإذن لها، فما أعدله من دين يحفظ للمجتمع المسلم لبناته ويحافظ على كيان الأسرة المسلمة، أكد ذلك وأعان عليه التعبير بالثرط "إِذَا" دون

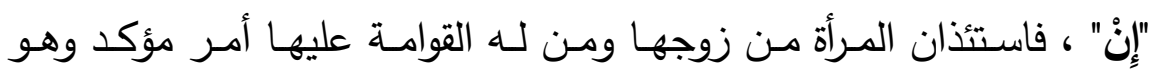
الأصل الذي يجب أن يكون عليه حال المرأة.

$\square$

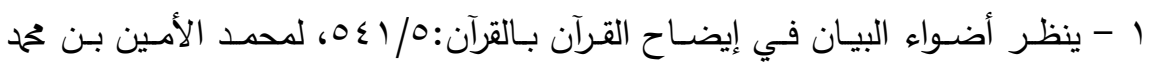

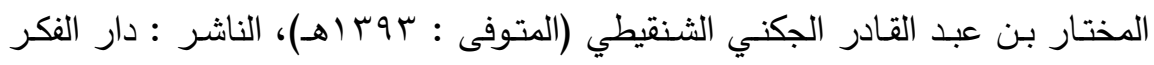

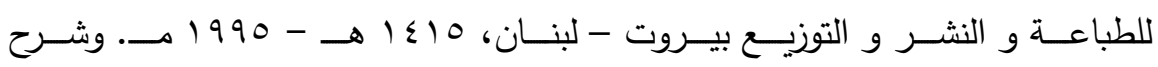

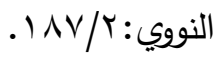




\section{هرانقة زوجها لها في الهج.}

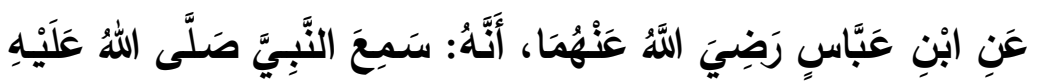

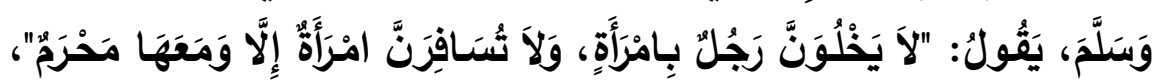

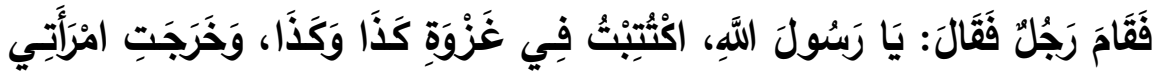

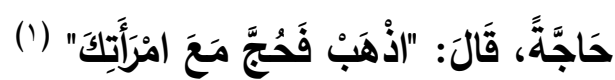
من حق الزوجـة على زوجها حسن معاشرتها، ومـن المعاشـرة الحسنة حجه معها، حتى لا تسافر وحدها، وتكون هناك الخلوة الدحرمة، ففي هذا الحديث يأمر النبي - صلى الله عليه وسلم - الرجل الذي أخبره بأن زوجته

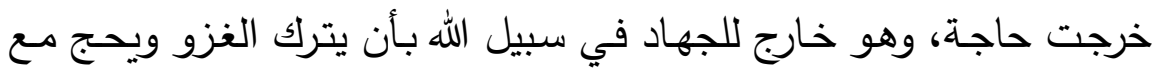
امرأته، ولم يأمر بإعادة المرأة لتحج في العام المقبل. وقد سلك الحديث النبوي الثريف عدة طرق للتأكيد على هذا الحق منها:

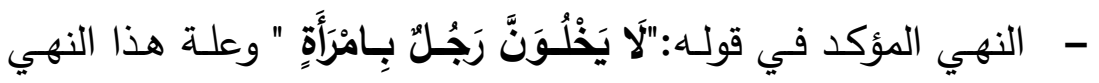

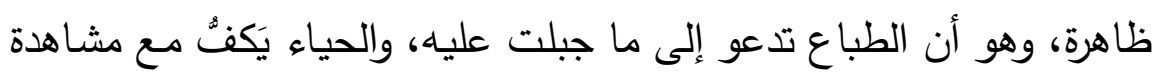
الخلق، فإذا كانت الخلوة عدم الحياء المـانع، فلم يبق إلا المـانع الديني. والإنسان يجري مع طبعه من غير تكلف، ويعاني مخالفة هواه حفظا للدين التاني

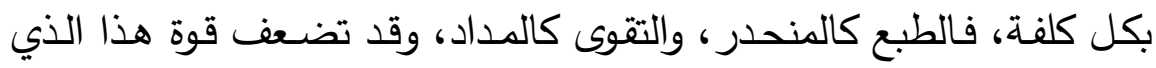

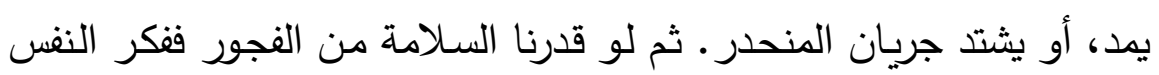

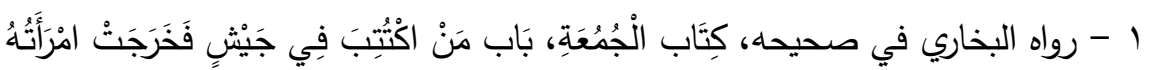

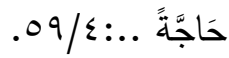


في تصوير ذلك لا ينفكان منهه أو أحدهما، فحسن الزجر عن ذلك.(') وقد جاء في رواية أخرى التحذير من الاختلاط والدخول على النساء الأجنبيات

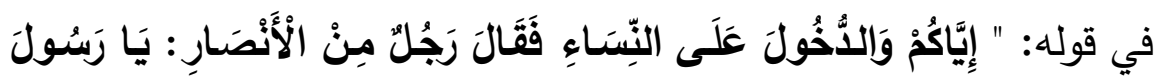

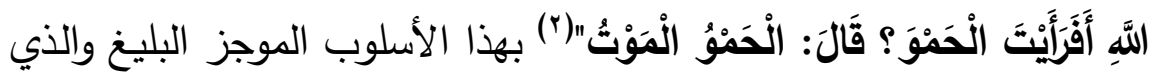
اتخذ أسـلوب التحذير "إِيَّـاكُم" طريقـاً لبيـان شـدة النهي، أي: اتقوا أنفسكم واحذروا الدخول على النساء، ومنع الدخول يستلزم منع الخلوة من باب أولى،

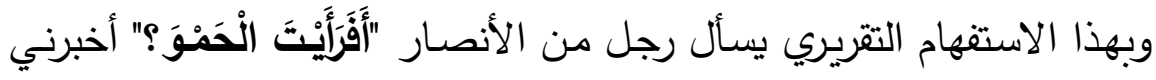
عن دخـول الحمـو على المـرأة، والحمـو: قريـب الزوج كأبيـه وأخيـه، وقيل: أقارب الزوج غير آبائه وأبنائه؛ لأن الخوف من الأقارب أكثر والفتنـة منهم أوقع؛ لتمكنهم مـن الوصـول إليها والخلوة مـن غير نكير عليهم، بخـلاف غيرهم، وعادة الناس المساهلة فيه وتخلي الأخ بامرأة أخيه، فهذا هو الموت. وبهذا التشبياه البليخ الموجز كان جـواب النبي - صـلى الله عليـه وسـلم "الحَمْوُ الْمَوْتُّ" حيث شبه دخول الحمو على المرأة بالموت في الثر والضرر والثدة والفظاعة، فلتحذر منه المرأة كما تحذر من الموت. وهذه الوجوه إنما تصـح إذا فسر الحمو بأخي الزوج ومن أشبهه من أقاربه كعمـه وابن أخته،

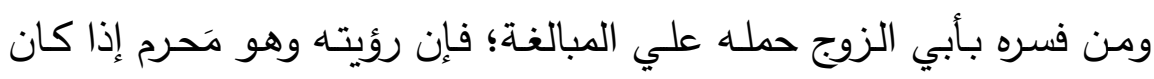
بهذه المثابة فكيف بغيره؟ أو أوّل الدخول بـالخلوة. وقيل: لمـا ذكر السـئل فئل

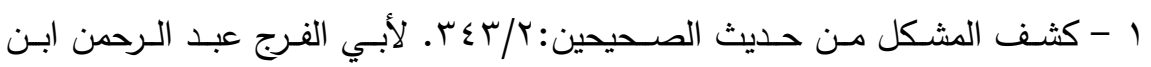

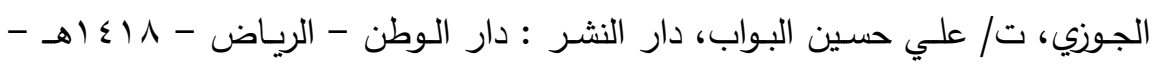
$.0199 \mathrm{~V}$

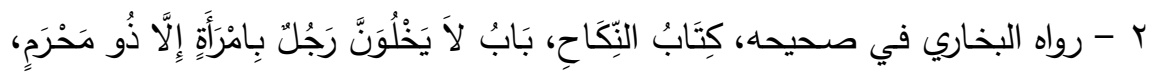

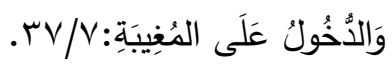


لفظـاً مجمـلاً محتملاً للمحرم وغيره، ردّ عليـه سؤالهه لتعميمهـه ردّ المغضَـب المنكر عليه. حيث يحتمل أن يكون دعاءً عليها أي: كان الموت منها بمنزلة الحمو الداخل عليها إن رضيت بذلك ، وفي الدعاء ادعاء أن الحمو نوعان: متعارف وهو القربب، وغير متعارف وهو الموت، وطلب لها غير المتعارف لما استفتى الرجل عن المتعارف مبالغة. (') - - تتكير "رجُل و امْرَأَةٍ " ليعم ويشمل جنس الرجال والنساء عدا الأزواج والمحارم، فيشمل النهي عن الخلوة كل بالغ من الرجال والنساء، لأنها مظنة الريبة ووسيلة إليها.

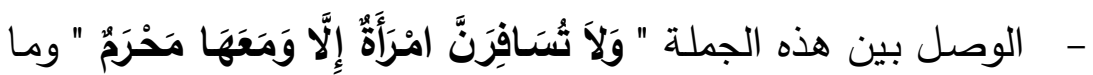
قبلها فالسفر من مظانّ الخلوة، فالمرأة إذا خلت عن محرم كانت كأنها في خلوة، ولا يؤمن عليها من جهة ميل طبعها إلى الهوى وعدم المحرم المدافع عنها. وجاءت هذه الجملة تأكيداً لما تضمنته الجملة الأولى من حرمة الخلوة بالأجنبية مطلقاً، فلا تحصل الخلوة مع وجود المحرم. وفي رواية "لَا ثُسَافِرْ

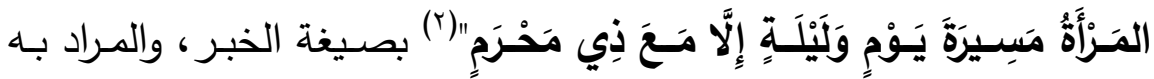
النهي، وهو أبلغ من النهي الصريح لما فيه من العناية والاهتمام بعدم سفر المرأة وحدها، ففيه تأكيد على طلب امتثاله حتى كأنه امتثل وأخبر عنه. كما أن في التعبير بالمعية "مَعَهَا" دلالة على المصـاحبة والملازمة لها، فلم يقل: إلا ولها أو يرافقها أو يلحقها مثلاً.

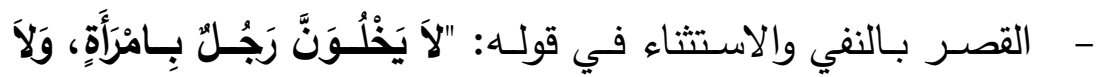

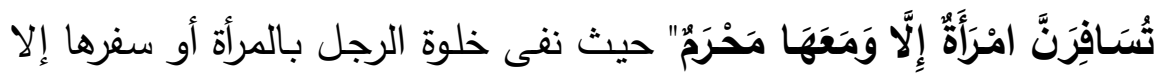

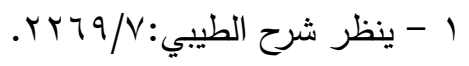

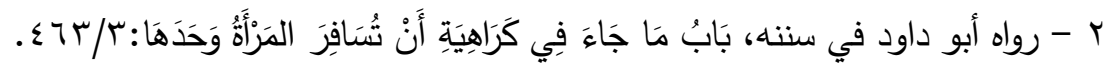

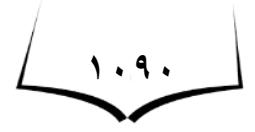


مع وجود المحرم حتى لا تغلب الشهوة والفتنـة عليهم، فوجود المحرم معها يمنع ذلك لغيرته عليها وذبه عنها. قال الكرماني: هذا استثناء من الجملتين

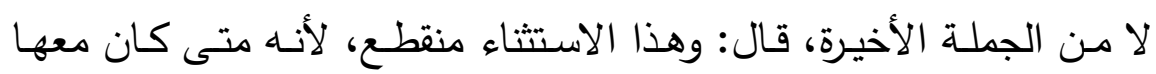

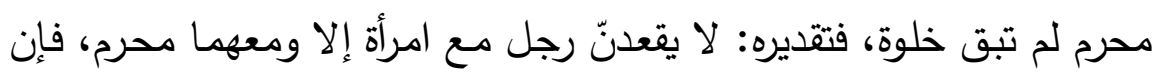
قلت الواو تقتضي معطوفًا عليه، قلت: الواو للحال، أي لا يخلون في حال

إلا في مثل هذه الحال.(')

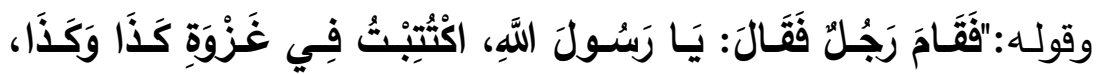

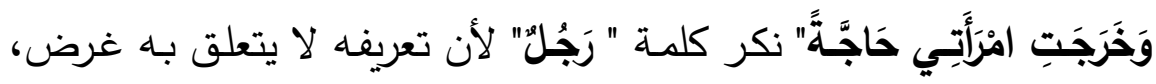
فالمقصود قيام واحد من جنس الرجال، وفي مناداته النبي - صلى الله عليه ويلـم - بـ "يَـا" الموضـوعة للبعيد دلالــة على شـرف وعلو منزلـة المنـادَى.

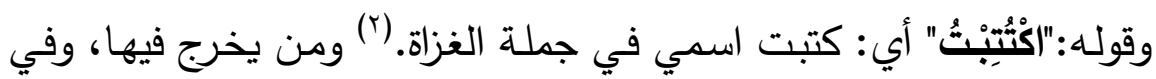
البناء للمفعول تركيز واهتمام على جعله ضمن من سيخرج مجاهداً في تلك

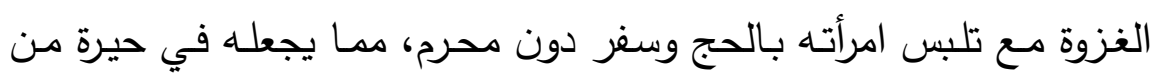

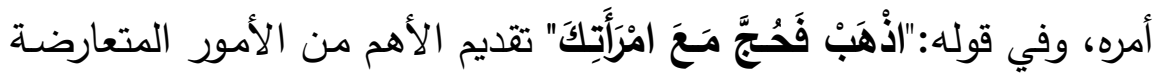
لأنـه لمـا تعارض سفره في الغزو وفي الحج معها رجح الحج معها، لأن الغزو يقوم غيره في مقامه عنه بخلاف الحج معها، فإذا قام بثخور المسلمين من فيه الكفاية لدفع العدو فلا بأس أن يأذن الإمام لمن له عذر في الرجوع؛

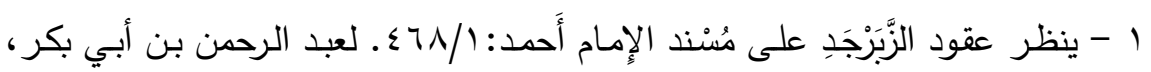

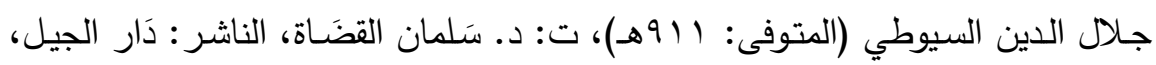

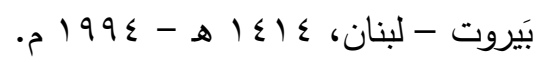

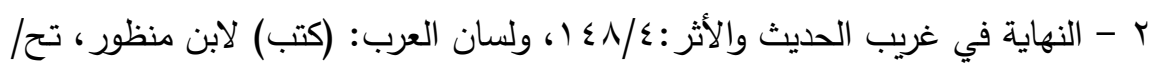
عبد الله على الكبير، محم أحمد حسب الله، هاشم تحمد الثاذلى، ط. دار المعارف بالقاهرة.

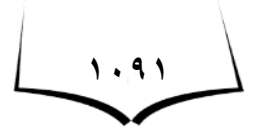


ولهذا المعنى أذن النبي للرجل أن يرجـع ويحج مـع امرأته، فـإن كان للعدو ظهور وقوة تعين فرض الجهاد على كل أحد فلا يأذن لله الإمام في الرجوع..

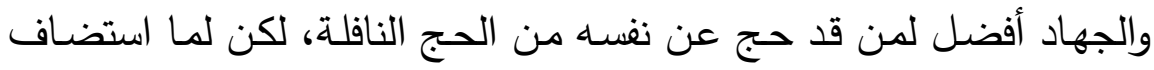

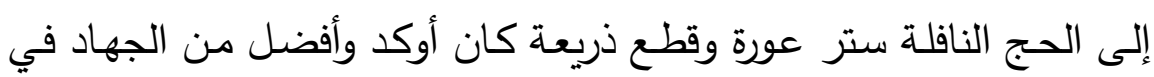
وقت قد استظهر المسلمون فيه على عدوهم. وهذا يـوحي بمدى حرص النبـي - صـلى الله عليها وسـلم - على أداء المرأة فريضـة الحج واستحباب مسارعة أولياء المرأة للحج بها وتحمل مشقة ذلك، ليظفر الحاج بها بمثل أجر جهادها، كما هو لها بحسن رعايتها لبيتها في جهاده، قال في الفتح: ويستفاد منه أن الحج في حق مثله أفضل من هن

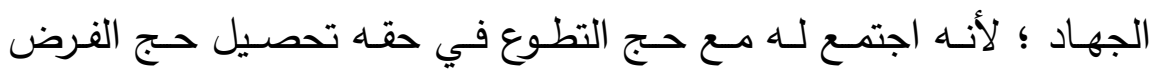
لامرأتـه، وكـان اجتمـاع ذلك لـه أفضـل مـن مجـرد الجهـاد الــي يحصـل

المقصود منه بغيره. (1) (1) وبمعاودة التأمسل في الحديث يلحظ غلبـة التأكيد عن طريق تكرار النهي، وتكرار النون الثقيلة، والقصر وذلك للمبالغـة في التأكيد على حفظ المرأة وصيانتها، وعدم تركها كلاً مباحاً للحيوانات الهملى التي لا ترعى ديناً أو خلقاً، وذلك بأحقيتها في مرافقة زوجها لها في الحـج وتقديم ذلك على نلى الجهاد، ممـا يؤكد على قيمة ومنزلة المرأة في الإسـلام، وأنها جوهرة ثمينة يجب أن يحافظ عليها من كل من ينتهك خبئها أو يقلل من قدرها.

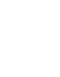

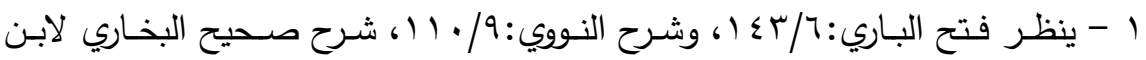

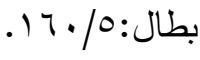

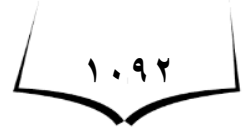




\section{المعاملة الطيبية وبيان فطرتها}

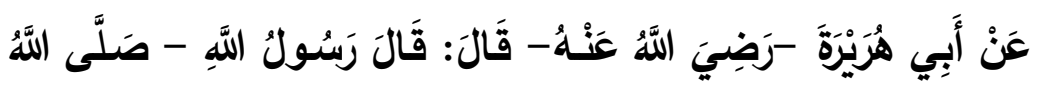

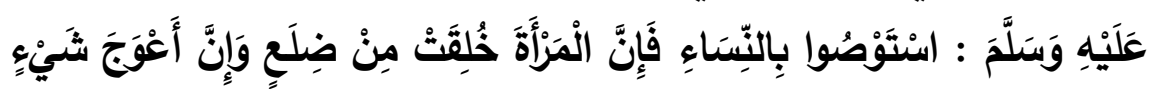

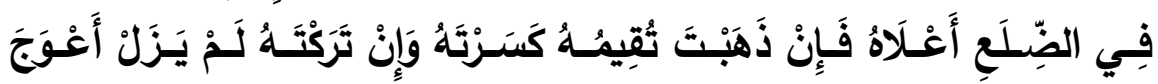

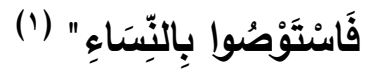

من حسن المعاشرة بين الزوجين الصبر على الزوجـة والترفق بها لطبيعة خلقتها، فإن من رام تقويمها فاته الانتفاع بها مع أنه لا غنى للإنسان عن امرأة يسكن إليها ويستعين بها على معاشه، فلا بد من الصبر على ما يقع منهن من اعوجاج والرفق بهن. وقد سلك البيان النبوي في سبيل تصوير ذلك وبيانه في هذا الحديث كثيراً من الألوان البلاغية منها:

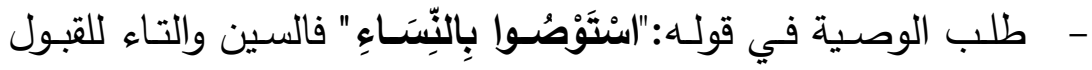
والمطاوعـة،أي أقبلـوا وصـيتي فيهن وأرفقوا بهن وأحسنوا عشرتهنّ ، وقـال الطيبي: السين للطلب مبالغـة، أي: اطلبوا الوصية مـن أنفسكم في حقهن بخير، وقال غيره، استفعل على أصله، وهو طلب الفعل فيكون معناه: اطلبوا

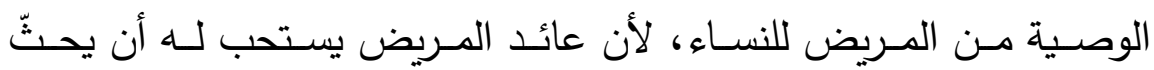
المريض على الوصية، وخصّ النساء بالذكر لضـفهن واحتياجهن إلى من يقوم بأمرهن، ويلزم من ذلك أن تحافظوا، لأن من وصّى غيره بشيء كان أحرص عليـه. والتعريـف في "النّبَسـاِِ" للجنس حيـث تشـمل الوصـية كل النسـاء، وذلك بأن يوصسي بعضـهم بعضـاً، وإن لم يكن فليطلبها من نفسـهـ

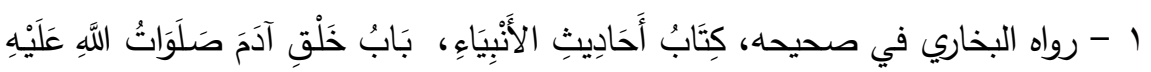

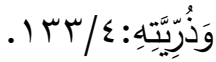

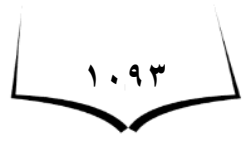




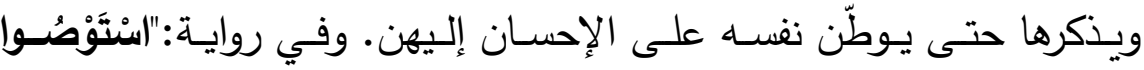
بِالنِّنَساءِ خَيْرًا" بتتكير "خَيْرًاً" ليعم ويشمل كل مـا من شـأنه الإحسـان للمرأة

وحسن عشرتها والصبر على أذاها لتدوم المودة ويقوى الرباط بينهما. (') - - توكيد الأمر السابق"اسنتَوْصُوا" والتأكيد فيه من ناحيتين: بالتعليل في

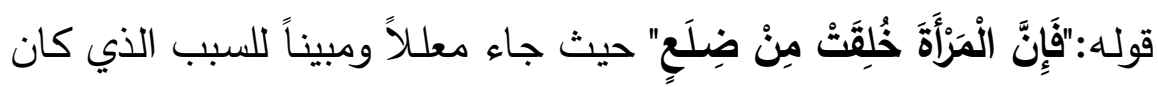
الوصـية لأجلـه، والتعليـل نفسـه تأكيد وتمكين للأكـر في النفوس، وإثبـات الثـيء معللاً أبلـغ من إثباته دون تعليل. والثانية: تأكيد التعليل نفسه حيث

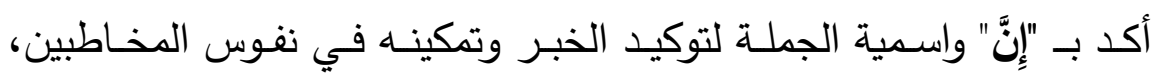

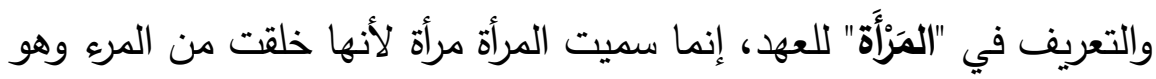
آدم - عليه السـلام، وفي "ضِـَعٍِ" إيجاز بحذف المضـاف إليه، تقديره ضـلع الرجل، وفي تتكيرها بيان للضعف والوهن، أي: أن حواء أخرجت من ضلع آدم - عليه السـلام. وفي بناء الفعل "خُلِقَتْ" للمفعول للعلم بالخالق وهو الله - جل وعـلا- وفيه مزيد من التركيز على أن هذا خلق الله ولا دخل للمرأة

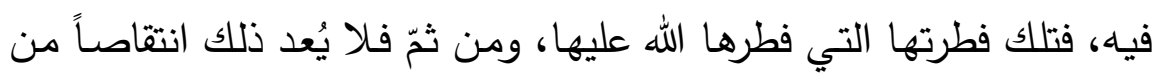
حقها أو سبباً في سوء معاملاتها. وقد صورت الاستعارة في قوله: "ضِـَلِعٍ" هذا المعنى وهو أن المرأة معوجة الطباع والتصرفات بخلقتها وطبيعتها كما خلق الضلع معوجاً، لا يسهل تقويمهما.وفيه كناية عن مداراتها والصبر على لى إنى اعوجاجها، وقيل: أراد به أن أول النساء حواء أخرجت من ضلع آدم الأيسر

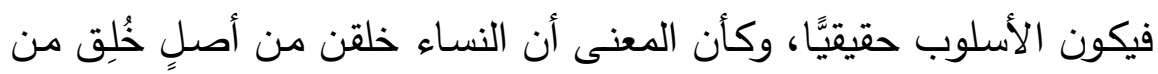
شيء معوج، وفيه إيماء إلى أن الإنسان يميل إلى الثيء الذي منـه خلق،

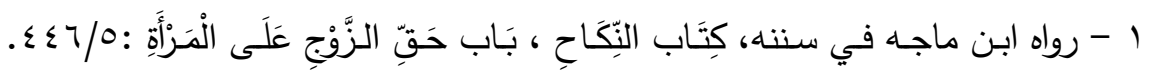

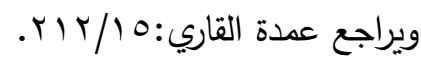

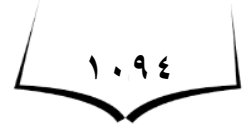


فأخلاق الأصسول تسري في الفروع، ولذلك سرى خلق حواء في بناتها إلى آخر الدهر، ولما كان أصلهن من ضلع أعوج كان لـه أثر في طباعهن وإلا فإن ما سوى حواء خلق من ماء كما قال تعالى : "وَاللهُ خَلَقَ كُلَّ دَابَّةٍِة مِنْ مَاءٍ" النور :0ء. وقد ورد في رواية أخرى ( ) التصريح بالتشبيه الذي بنيت

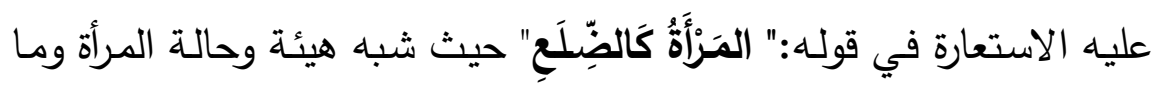
فطرت عليه من خلال بهيئة وحالة الضلع، لأنها عوجاء مثله لأن السيدة حواء خلقت منه فالنساء لها تبع، وفي هذا حثّ للأزواج على حسن معاملة الزوجات وملاطفتهن والصبر على ما قد يقع منهن من الأذى، وعلى عوج

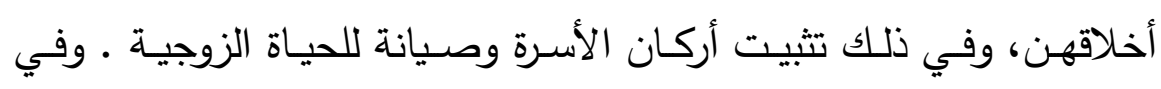
تشبيهها بالضـلع إيمـاء إلى الأصـل الذي يجب أن تكـون عليهـ المـرأة مـن

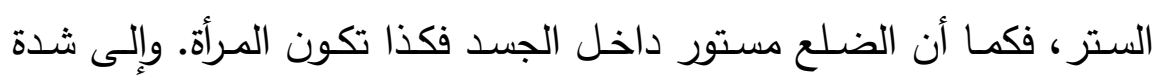
حاجتها إلى الرجل فقد خلقت من ضلعه لتكون بجانبه وقريبة من قلبه، وفي التشبيه بالضلع تصوير وتجسيد لمعنى الحنو الذي فطرت عليه المرأة.

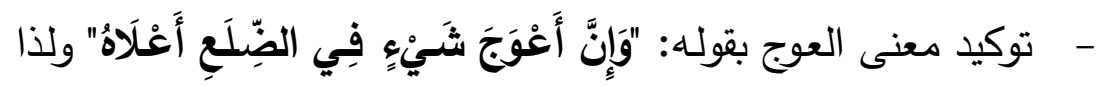

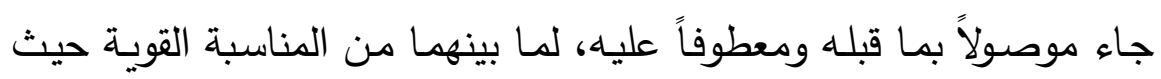
ذكره تأكيداً لمعنى الكسر، أو إشـارة إلى أنها خلقت من أعوج أجزاء الضلـع مبالغة في إثبات هذه الصفة لهن، أو ضرب مثلاً لأعلى المرأة لأن أعلاها

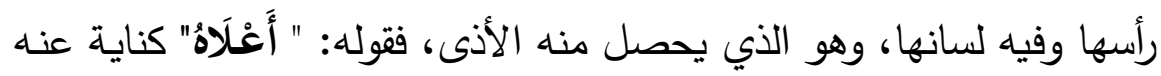

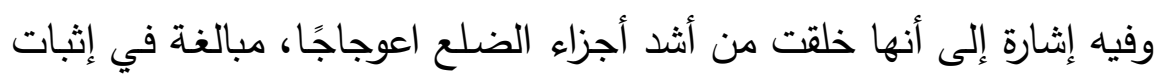

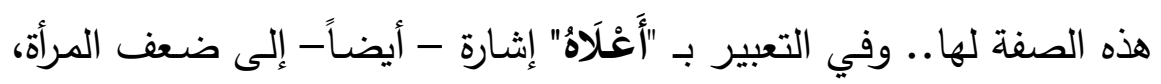

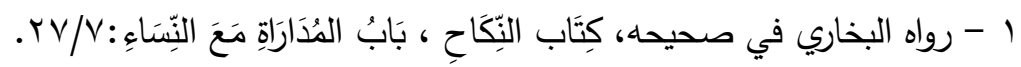

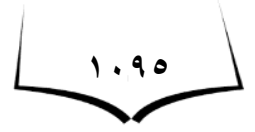


فإن أضعف الثيء أعلاه، بخلاف بقية الأجزاء، وهذا يومى إلى الترفق بهنّ وعدم القسوة في معاملتهنّ. ولفظ "أَعْوَجَ" صفة مشبهة، وليس أفعل تفضيل، لأن أفعل التفضيل لا لأن يأتي من ألفاظ العيوب التي صفتها على وزن "أفعل" وقيل: هو أفعل تفضيل شذوذًا، أو محل المنـع عند الالتباس بالصفة، فإذا تميز عنها بالقرينـة فلا منع. وفائدة هذه المقدمة بيان أنها خلقت من الضلح الأعوج وهو الذي في أعلى الضلوع أو بيان أنها لا تقبل الإقامة لأن الأصل في التقويم هو أعلى لهى

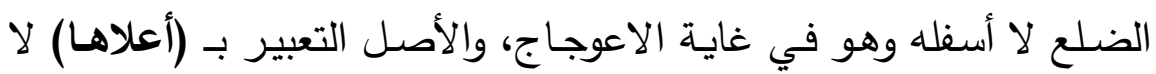

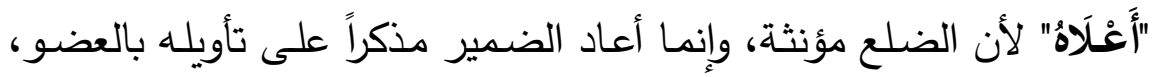
وقيل: تأنيثه غير حقيقي فلذا جاز التذكير ، ورُدّ: بأن معاملة المؤنث غير مرير الحقيقي معاملة المذكر إنما هو بالنسبة إلى ظاهره إذا أسند إليه مثل: طلع الثمس، وأما مضمره فحكمه حكم المؤنث الحقيقي في وجوب التأنيث تقول: الثمس طلعت وهي طالعة ولا تقول طلع وهو طالع. وقد يؤول في بعض المواضع بالمذكر فينزل منزلته كقول الثاعر :

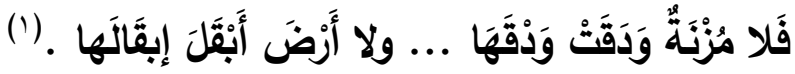

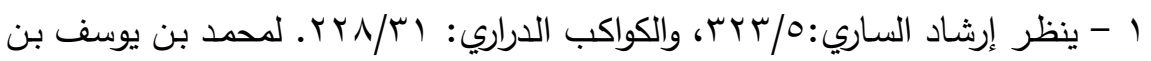

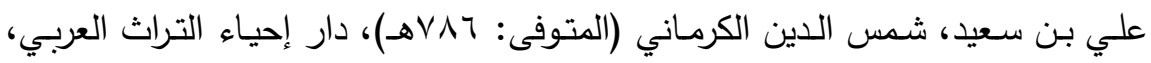

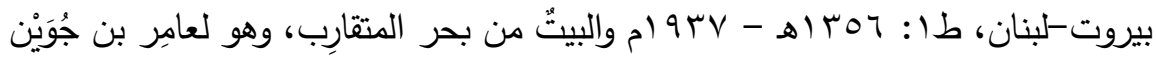

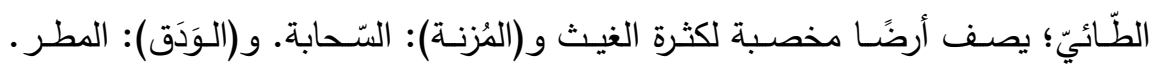
و(أبقلتُ) أخرجت البقل؛ وهو من النّبات ما ليس بشجر • والثّاهدُ فيه: (ولا أرض أبقل

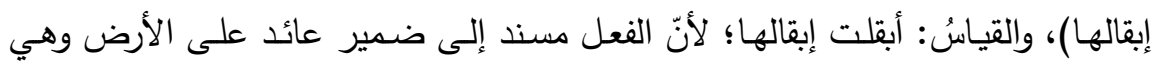

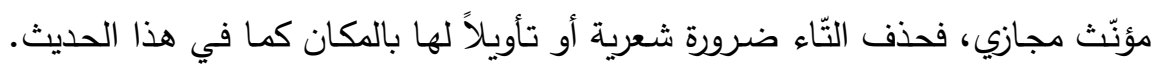
$==$ 


\section{مجلة قطاع كليات اللفة العربية والشعب المناظرة لها العكد [r]]}

وأميل إلى أن المخالفة في الصيخ دلالة على مخالفة من يروم إقامـة الضلع وجعله مستقيماً، فلكي يؤدي الضلع وظيفته على أكمل وجها أن يظل على اعوجاجه وكذا المرأة فوجب الاستمتاع بها على حالتها وعدم الطهع في استقامتها، فلو كانت كالرجل لناطحته في كل مـا يكون لـه وبذلك يختل النظـام المجتمعي القويم، فـالمرأة خلقت أضـفـ من الرجل، فهـي أقلُّ منـهـ عملاً وإنتاجًا، وأقل منه رَغْبَة في الطموح؛ لأنها خلقت ضعيفة، وذلك بسبب

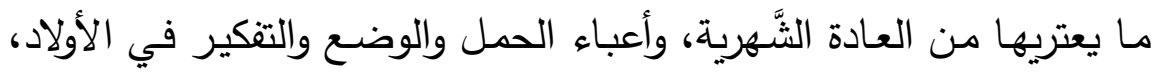

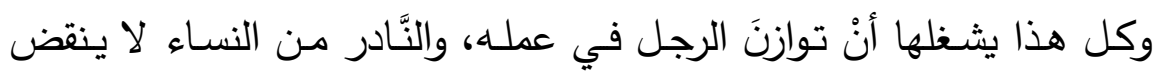
القاعدة، ولذا وصفهن - صلى الله عليه وسلم - بسبب هذا الضَّعف الذي

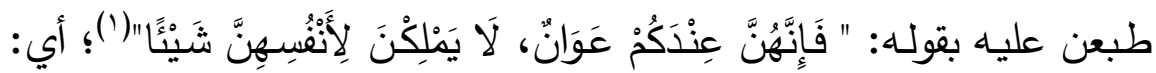

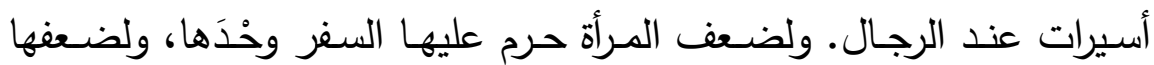

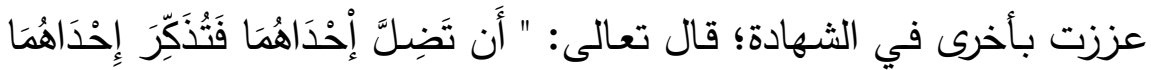

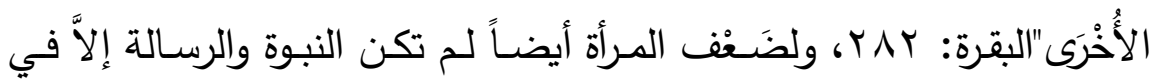

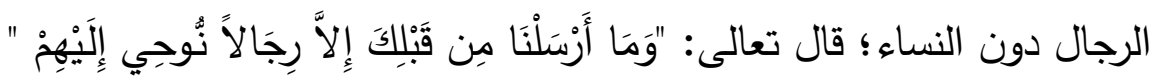

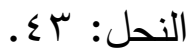

- ومما يؤكد الصبر عليهن وحسن عشرتهن الاستعارة والتوكيد بالثرط

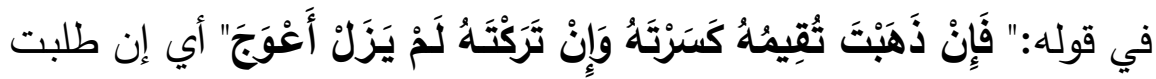
منها تسوية اعوجاجها أدّى إلى فراقها فهو ضَرْبُ مثلٍ للطلاق، فـلا سبيل إلى استقامة طباعهن، حيث شبه الطلاق بالكسر بجامع عدم الصـلاح في

$$
==
$$

ينظر شرح الرضـي على الكافية: / / عـ ـ لرضسي الدين الأستراباذي، تصـحيح وتعليق:

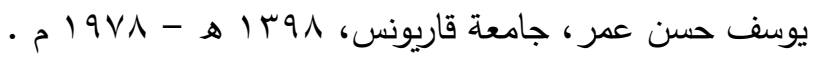

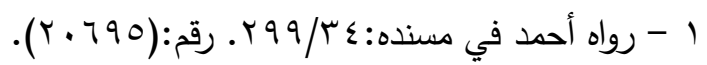


كل، ويؤيد ذلك التصريح به في رواية مسلم: "وَإِنْ ذَهَبْتَ تُقِيمُهَها، كَسَرْتَهَا

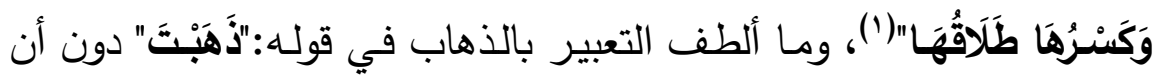

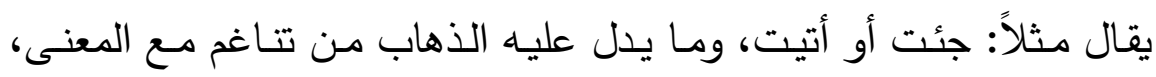

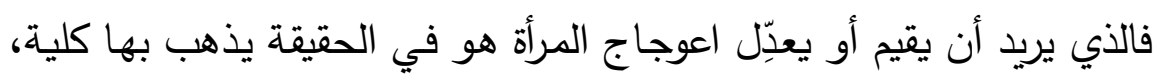
فكان التعبير بالذهاب هنا أبلخ وأدق من غيره في إصابة المعنى.

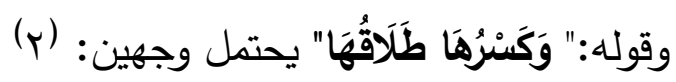

أحدهما: أن يكون المعنى: أنك متى أردت أن تقيمها طلقتها. والآخر : أنك تستغني عن كسره بأن تطلقها. وقد يكون الكسر أعم من ذلك فيشمل الكسر المعنوي وما يترتب عليه من أثر نفسي يكون أثد من الحسي، فأثر

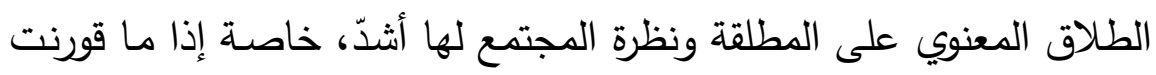

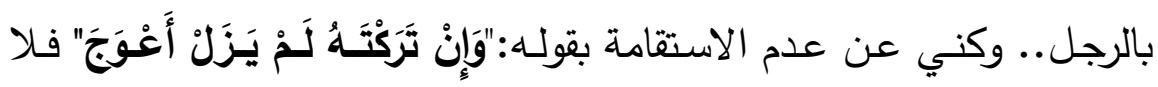
مطمع في استقامتهن. وفي انكسار الضـلع اختلال لتوازن الجسد وفسـاد لحالـه كذلك كل من يروم إقامة اعوجاج المرأة سيؤدي ذلك إلى خلل في بناء الأسرة، فالضلـع يستعصي على الاستقامة، فيجب الانتفاع به على ما فطر عليه، فهو شديد صلب، وهو مـع انحنائـه لا يقبل الاستقامة، وفي استقامته فقدانـه ومفارقته

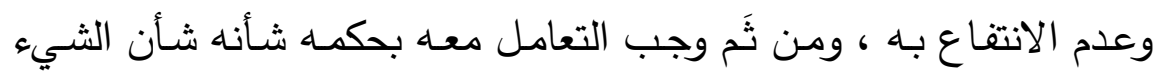

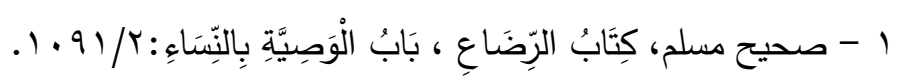

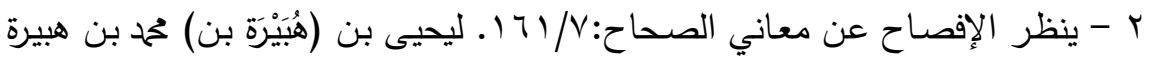

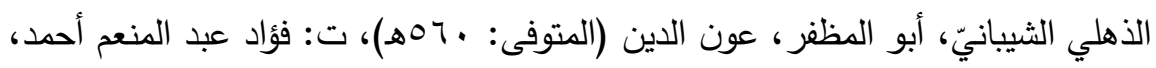

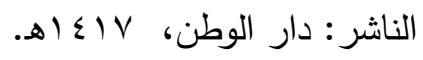

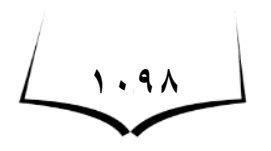




\section{مجلة قطاع كليات اللفة العربية والشعب المناظرة لها العكد [r]]}

الصلب، خاصـة أنه مع شدته وصـلابته يكون داخل الجسد يضطرب الجسد ويتألم بفقدانه أو كسره، وعليه فلا استقامة لحياة الرجل وبناء أسرته من غير امرأة يصبر على عوجها ويستمتع به، ويحسن إليها إحسانه لضلعه. فطبيعة المرأة فيها صفة الانحناء والانعطاف، وهذه صفة مدح لها تتميز بها عن ون ونه الرجل، فالاعوجاج في الضلع لا يعد عيباً فيه، فهو يحمي ما بداخله، فهي تحمي أسرتها وتحنو على أطفالها وتفيض عليهج بالعطف والحنان وهذه من أهم خصائص المرأة التي تميزت بها في خلقتها، ولذا كان التأكيد على هذه الصـفة عنـد التعامـل معهـا، ولتأكيد هـذا المعنى وتثبيتهـ في الـنف كـان التفصيل بعد الإجمال، فقد أجمل الحديث وأبهـم في قولـه:"ضِـــعِ" ثم كـان

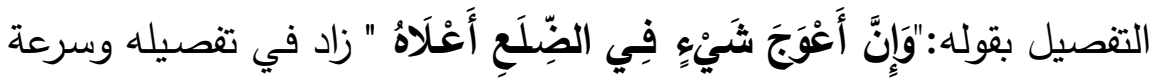
بيانه وأكده العطف بالجملتين الثرطيتين بالفاء والوصل بينهما في قوله::"فَإِنْ

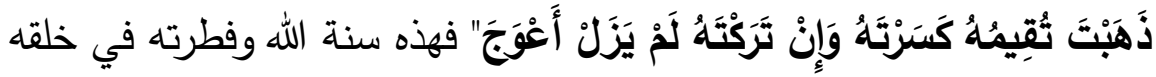
للمرأة فوجب التسليم والانقياد لأمر الله تعالى، فالمنفعة في الانتفاع به بحالته التي خلقـه الله عليها، ومحاولـة تقويمـه لا تكون إلا بكسره، ومحاولـة تعديل بعض سلوكيات المرأة وتصرفاتها لا تكون إلا بالفراق.

ومجيء جواب الشرط ماضياً " كَسَرْتَهُ" مـع أن الأسلوب لو كان

على وتيرة واحدة لقيل: تكسره بصيغة المضـارع؛ حتى يتناسب مـع مـا قبله "تُقِيمُهُه" ولعل ذلك لإفادة تحقق الكسر وذلك إذا ما حاول الرجل تقويم هذا الاعوجاج، وهو بذلك يقطع الطريق على كل من يروم تعديل هذا العوج • وقد سارت السنة النبوية على خطى ما جاء في القرآن وبينته، فقد قال تعالى آمـراً بالمعاشـرة بـالمعروف وبيـان أن الخير قد يكون فيمـا يكرهـه الإنســان: 
"وَعَاشِرْروهُنَّ بِالْمَعْرُوفِ فَإِنْ كَرِهْتُمُوهُنَّ فَعَسَسى أَنْ تَكْرَهُوا شَيْيًَا وَيَجْعَلَ اللَّهُ

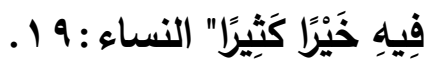

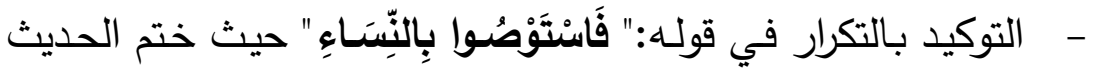
بمـا بـدأ بـه وهو الوصية بالنسـاء، فمن سنن العرب التكريـر والإعـادة إرادة الإبلاغ بحسب العناية بالأمر، وإرادة التوكيد والإفهام، وهو كثير في السنة النبوية، فالنبي - صلى الله عليه وسلم - إنما يتكلم بلغتهم وعلى مذهبهم في الكلام، فكرره زيادة في التأكيد وشدّة المبالغة في الوصية بهن . وهذا يومئ إلى تقويمهن برفق بحيث لا يبالغ فيه فتطلق أو يؤدي ذلك إلى الطلاق، ولا يتركها فتستمر على الاعوجاج إذا تعدت بما طبعها الله عليه إلى المعصية أو ترك واجب أوجبه الله عليها، وإنما يتلطف معها في الأمور المباحة. وهذا الحديث من أبلغ الكلام وأحسن التشبيه، والمراد أنه لا ينبغي للرجل أن يطهـع في استقامة المرأة كل الاستقامة فمـن حاول حملها على واحلى الأخلاق المستقيمة أفسدها، ومن تركها على ما هي عليه انتفع بها، وفيه

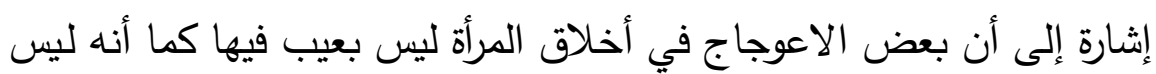
بعيب في الضـلع فلا ينبغي للرجل أن يطلب فيها أخـلاق الرجـال، فإن الله

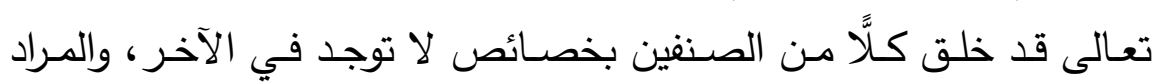

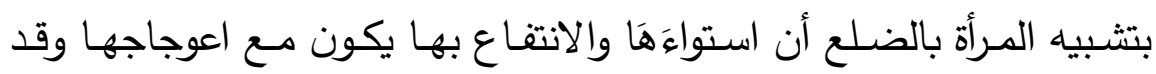
صاغ ذلك الشاعر مقتبساً من هذا الحديث قوله :

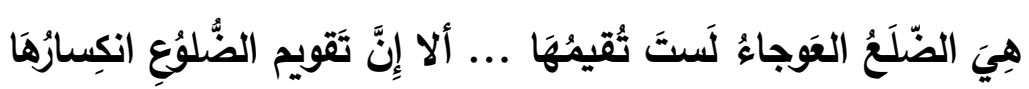




\section{مجلة قطاع كليات اللفة العريبة والشعب المناظرة لها العذ [با]}

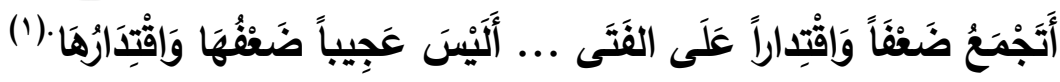
كما أن تكرار التوصية بالمرأة في البدء والختام يجعل الحديث كله

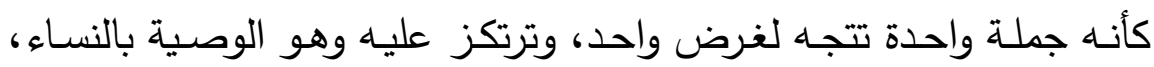
وفهم طبيعتهن وقبولهن على ما هن عليه.

\section{التغاضي عن بعض ها يكون هنها}

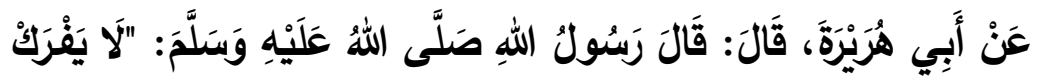

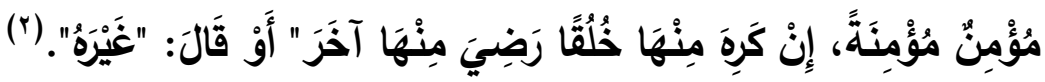
لهذا الأدب النبوي الرفيع يرشدنا النبي - صلى الله عليه وسلم - إلى حسن العشرة وينهانا عن بغض الزوجة بمجرد كراهة خلق من أخلاقها فإنها لا تخلو من خير - n

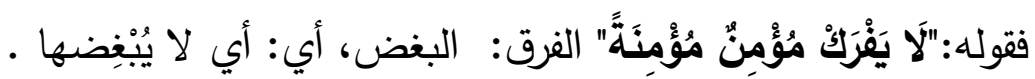

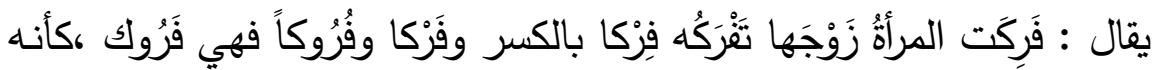

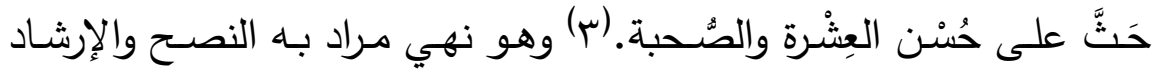
لأمته، إنه منهاج يجب اتِبّاعُه في جميع العلاقات بين الناس، وأخصٌ هذه العلاقات ما جاء هذا الحديث بخصوصـه، وهو العلاقة بين الزوج وزوجته، فَمَن ذا الذي سلمٍ من عيوب ونقص؟! فلا ينبغي للرجل أن يبغضها؛ لما يرى

1 - البيتان من بحر الطويل، وهما للحاجب بن ذبيان في لسان العرب:(ضلع)، وينظر

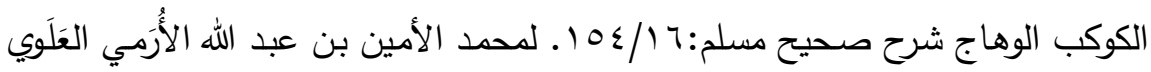

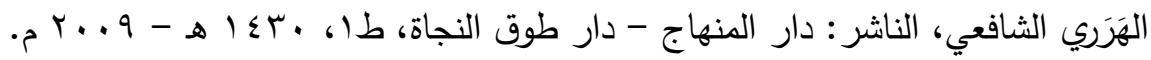

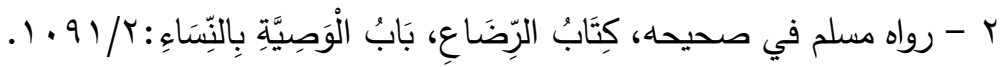

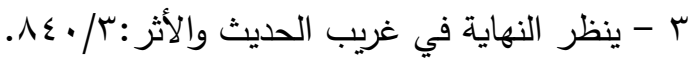

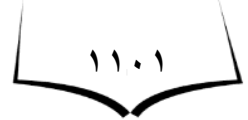


منهـا مـا يكرهـه؛ لأنـهـ إن كره منها خلقاً، فلعله يستحسن غيره، فيكون هذا مقابـل ذاك. وإذا كانـت مشتملة على المحبوب والمكروه فـلا ينبغي ترجيح مقتضى الكراهة على مقتضى المحبة. فهذا من أكبر الأسباب والدواعي إلى ولى حسن العشرة بالمعروف، فنهى المؤمن عن سوء عشرته لزوجته. والنهي عن الثـيء أمر بضده. وأمره أن يلحظ ما فيها من الأخـاق الجميلة، والأمور التي تتاسباه، وأن يجعلها في مقابلة مـا كره من أخلاقها؛ فالمؤمنـة يحملها الإيمان على استعمال خصـال محمودة يحبها المؤمن، فيحمل مـا لا يحبـه على مـا يحبـه، فـإن الزوج إذا تأمـل مـا في زوجتـه مـن الأخـلاق الجميلـة، والمحاسن التي يحبها، ونظر إلى السبب الذي دعاه إلى التضجر منها وسوء عشرتها، رآه شيئاً واحداً أو اثنين مثلاً، وما فيها مما يحب أكثر ـ فإذا كان منصفاً غض عن مساوئها لاضدحلالها في محاسنها. وبهذا تدوم الصحبة، وتؤدّى الحقوق الواجبة والمستحبة، وربما أن ما كره منها تسعى بتعديله أو تبديله. وأما من غض عن المحاسن، ولحظ المساوئ ولو كانت قليلة، فهذا مـن عدم الإنصـاف، ولا يكـاد يصفو مـع زوجتـه. ومـن العلمـاء مـن جعل

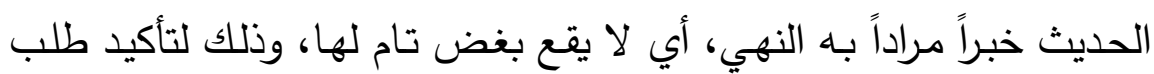
امتثالـه حتى كأنـه امتثل وأخبر عنـه، والصـواب أنـه نهي أي ينبغي أن لا

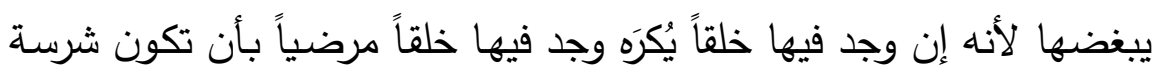
الخلق لكنها ديّنَة أو جميلة أو عفيفة أو رفيقة بـه أو نحو ذلك. وهذا يتعين من وجهين أحدهما: أن المعروف في الروايات لا يفرك بإسكان الكاف لا

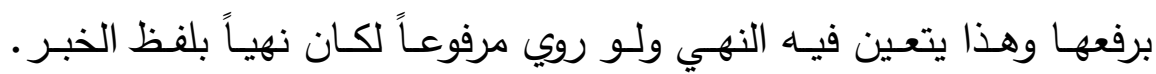

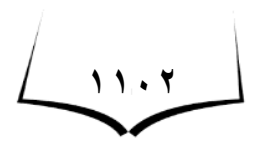




\section{مجلة قطاع كليات اللفة العربية والشعب المناظرة لها العكد [r]]}

والثاني: أنه قد وقع خلافه فبعض الناس يبغض زوجته بغضـاً شديداً ولو كان خبراً لم يقع خلافه وهذا واقع. (')

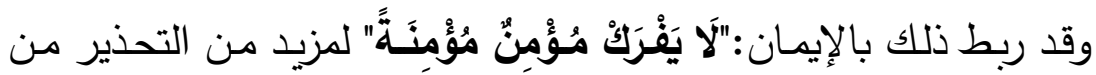

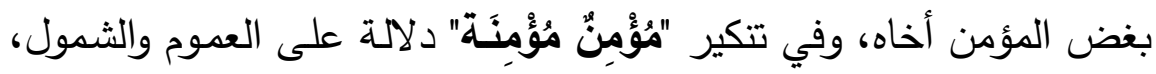

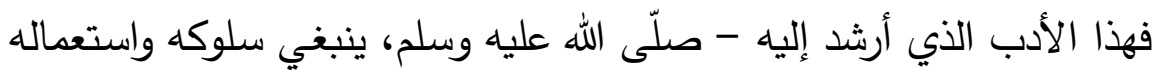
مع جميع المعاشَرين والمعاملين؛ فإن نفعه الديني والدنيوي كثير وصاحبه قد سعى في راحة قلبه. وأقرب المعاشَرين للمؤمن زوجته، وقد وصفهما بالإيمان

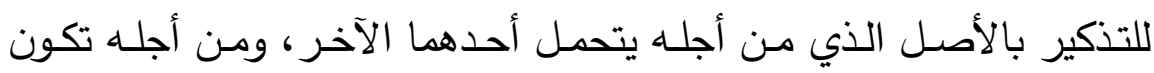
المعاملة الحسنة ، وجميل المعاشرة. ولذا جاء التعليل بالجملة الشرطية :"إنْ

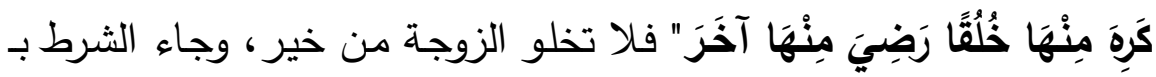

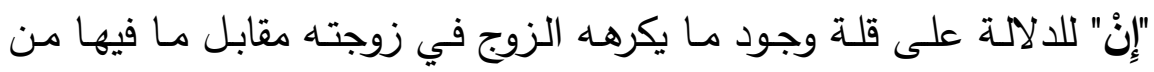
خير ، ساعد في ذلك تتكير "خُلُقًا"، والطباق بين "كَرِهَ و رَضِسيَ" • وفيه إشَارة

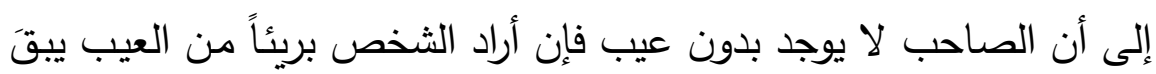

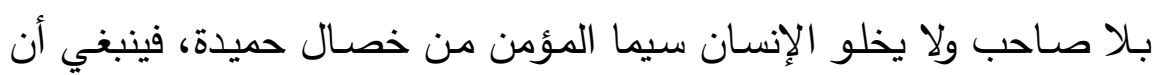
يراعيها ويستر ما ينافيها، وإذا كانت الزوجة مشتملة على المحبوب والمكروه فلا ينبغي ترجيح مقتضى الكراهـة على مقتضى المحبة.وذلك لأن الإنسـان يجب عليه القيام بالعدل، وأن يراعي المعامل لله بما تقتضيه حاله، والعدل

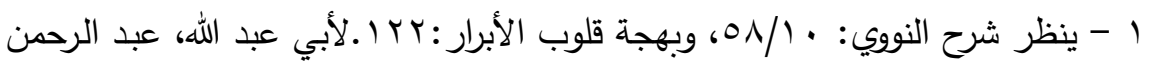

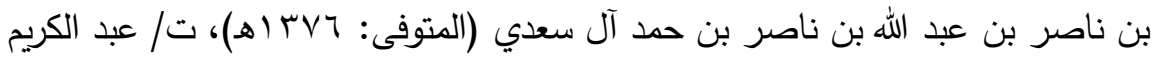

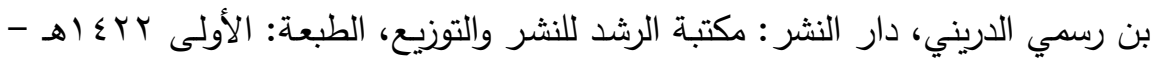


أن يوازن بين السيئات والحسنات، وينظر أيهــا أكثر وأيهمـا أعظم وقعـاً، فيغلب ما كان أكثر وما كان أشد تأثيراً؛ هذا هو العدل. قال تعالى :"يَا أَيْهَا

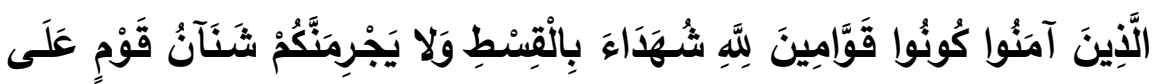

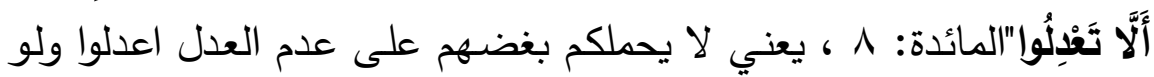

كنتم تبغضونه. (1)

وهذا الحـديث يتـآزر مـع الحـديث السـابق في بيـان عنايـة الإسـلام

بالمرأة، ودعوة الرجل إلى فهم طبيعتها.. ففي الحديث السـابق يأمر الرجل بالتحمل وسعة الصدر معها لما تشتمل عليه من اعوجاج في أصل الخلقة، وهنا ينهاه عن بغضها بمجرد رؤية ما يسوءه منها..

\section{الاستمتمتاع بزوجها}

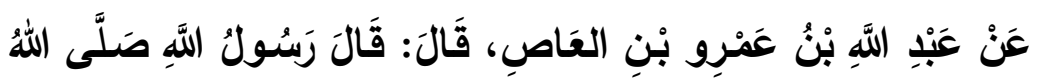

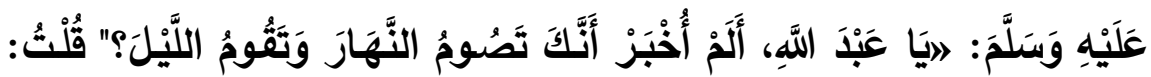

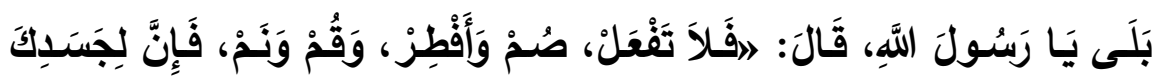

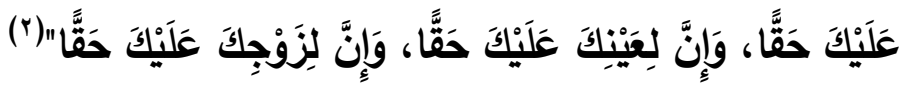
في هذا الحديث يأمر النبي - صلى الله عليه وسلم - بالتوسط في نوافل العبادات والطاعات من صيام وقيام ونحوه، مع المحافظة على الحقوق البدنيـة والنفسية والاجتماعية من طعام وشراب ولباس ونوم وراحـة وزوجـة وولد وغيرهـا، ففي ذلك صـلاح الإنسـان واستقامته، ونفعـه غيره. وقد جسد البيان النبوي ذلك وصوره في هذا الحوار الذي دار بين النبي - صلى الله

I - ينظر مرقاة المفاتيح:11/1)

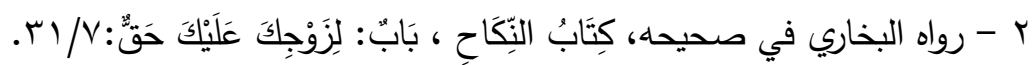

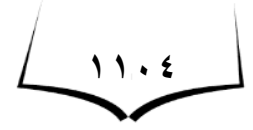




\section{مجلة قطاع كليات اللفة العربية والشعب المناظرة لها العكد [r]]}

عليه وسلم - وعبد الله بن عمرو بن العاص - رضي الله عنهما - حيث بدأه

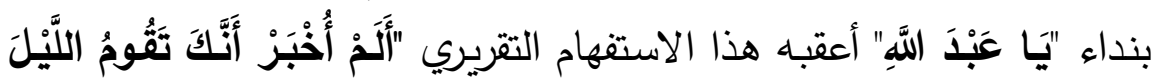
وَتَصُومُ النَّهَارَ" لما فيه من جذب للانتباه وتمهيد وتقرير لقبول ما سيترتب عليه، وبناء الفعل "أُخْبَرْ" للمجهول لتركيز الاهتمام على مضمون الخبر وهو استمرار قيامه الليل وصومه النهار ، ساعد في بيان ذلك مضارعية الصيغة في "تَقُومُ وَ تَصُومُ" وتوكيد الخبر بأكثر من مؤكد ( أنّ واسمية الجملة وتقديم

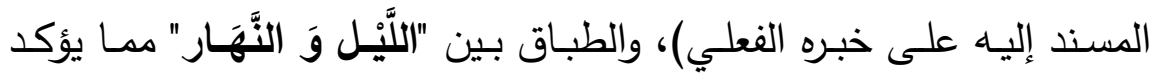
مداومته على العبادة التي لا يتعدى نفعها غيره وذلك في جميع أوقاته. وكان أبوه قد زوجه بامرأة ذات حسب، وكان يتعاهدها فيسألها عن زوجها، فتقول، نعم الرجل من رجل لم يطأ لنا فراشاً ولم يفتش لنا كنفاً كناية عن أنه لا يباشرها، وذلك لانشغاله طول حياته بالصيام والقيام، فذهب أبوه إلى النبي - صلى الله عليه وسلم - وأخبره بحالله،فنهاه النبي - صـلى الله

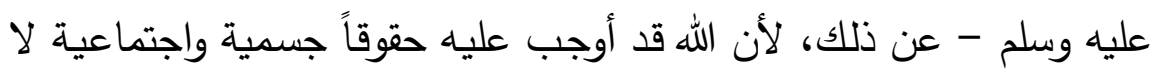
بد أن يؤديها، فحق الجسم أن يعطيه نصيبه من النوم والراحة، وحق الزوجة أن يجعل لها وقتاً لمعاشرتها ومباشرتها، وحق الزائر أو الضيف أن يستقبله ويكرمسه، ويؤانسـه فإذا أعطى للعبادة وقته كله قصر في أداء هذه الحقوق

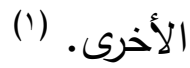

وهذه الحقوق جميعها جـاءت مؤكدة بأكثر مـن مؤكد ومنها حق

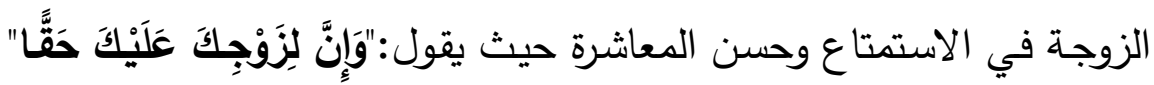

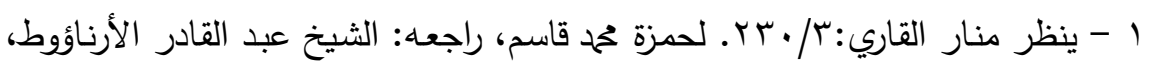

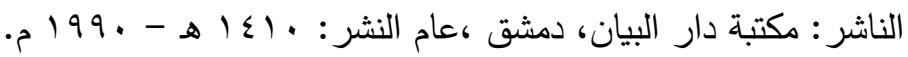


حيث أكدّ هذا الخبر بـ إن، واسمية الجملة، ودخول اللام على الخبر، وتقديم الجار والمجرور "عَلَيْكَ" ليؤكد على هذا الحق الواجب عليه، ودلّ على عظمهـ تتكير "حَقَّا"، والحديث كنايـة عن التوسط والاعتدال في كل الأمور . جاء مؤكداً ومبيناً ما جاء في القرآن الكريم يقول الله تعالى: "وَابْتَتِغ فِيمَا آتَالََّ اللَّهُ

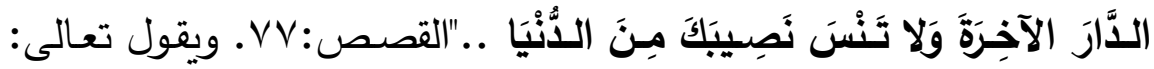

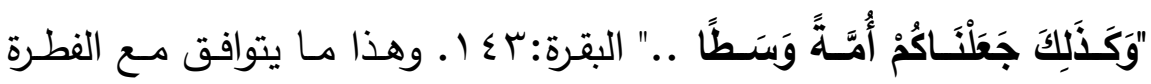
السليمة، التي تراعي حاجات الروح ومطالب الجسد، وتوازن بين العمل للدنيا والعمل للآخرة، وفي ذلك تهذيب لغرائز الإنسـان الذي هو مزيج من روح

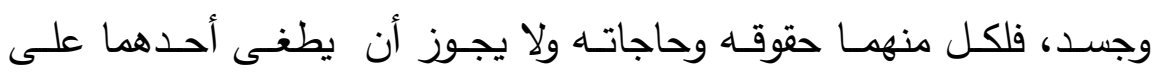
الآخر • للتناسب بين هذه الحقوق كان الوصل بينها، حيث بدأ بالأعم وهو (الجسد) فقال:"إِنَّ لِجَسَدِكَ عَلَيْكَ حَقّاً " وذلك بالمحافظة على الأكل والشرب، والقيـام والنوم؛ لأنـه يحصـل بصـيام الأيـام وقيـام الليـالي على وجـه الدوام انحلال للقوى، واختلال للبدن عن النظام، فلا يجوز للك إضـاعته بتفربطه

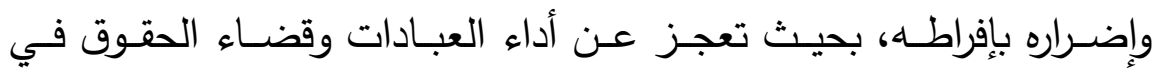
الحالات، أتبعه بالأخص وهو (العين) فقال:"وإِنَّ لِعَيْنِكَ عَلَيْكَ حَقّاً " والمراد بها: الباصرة، وقيل: الذات، تأكيداً للجملة الأولى، والأول أولى لأن التأسيس أقوى من التأكيد، ثم من المعلوم نقصان قوة الباصرة من النوم والسهر ، وقلة الطعام والثراب حيث يؤدي ذلك لغوار العين، كما أن كثرة البكاء - أيضـاً والتي تكون في القيام وقراءة القرآن قد تضعف العين أو تذهب بها، فهذه

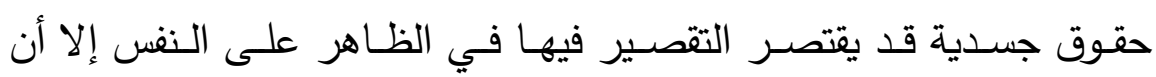

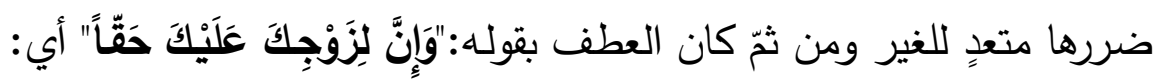

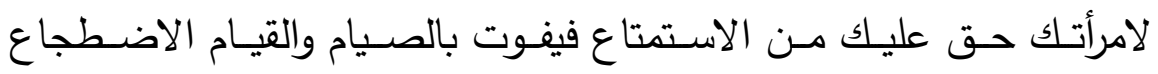

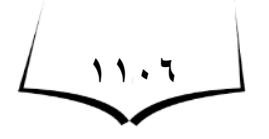




\section{مجلة قطاع كليات اللفة العربية والشعب المناظرة لها العكد [r]]}

والانتفــاع فيعجـز عـن القيـام بحسـن المعاشـرة المــأمور بهـا فـي قولــه:

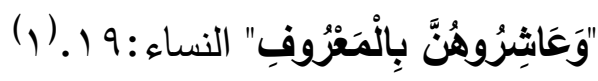

وعلى هذا فترتيب هذه الحقوق في الحديث جاء على نظم بديع، إذ هي مرتبة ترتيباً دقيقاً، فإعطاء الجسد حقه يعطي العين حقها من النوم والراحة، وهذا بلا شك يجعله يعطي زوجه حقها، وإهمال الأول منها يترتب عليه إهمال لباقي الحقوق.

\section{الحق في النفقة.}

عَنْ عَائشََةَ - رضي الله عنها - أَنَّ هِنْدَ بِنْتَ عُتْبَةَ، قَالَتْ : يَا رَسُولَ

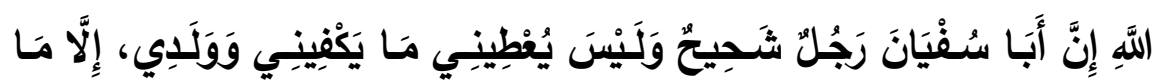

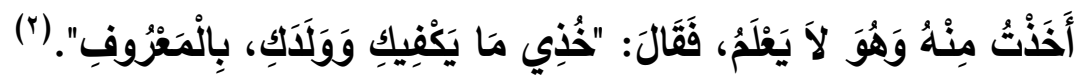
هذا الحديث يبين حكم النبي - صلى الله عليه وسلم - في شكوى جاءته، من هند بنت عتبة تشكو إليه تقتير زوجها أبي سفيان عليها وعلى

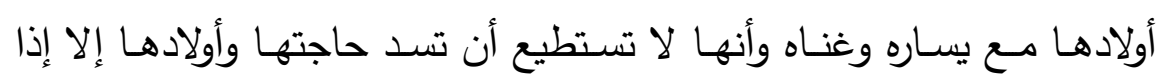
أخذت من ماله سرا، فاستفتت النبي - صلى الله عليه وسلم - في إثم ذلك؟ فأفتاها بأن تأخذ من ماله ما يكغيها وأولادها بما جرت به العادة والعرف. وكان التقديم والتهيئة لمطلوبها وبيانه بكثير من المهيئات منها:

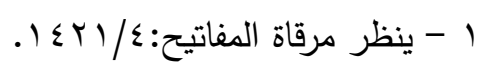

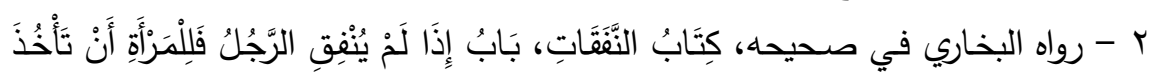

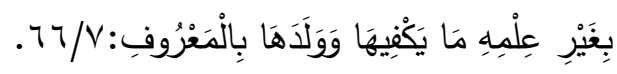


- - النداء بـ "يَـا" الموضـوعة لنداء البعيد دلالـة على رفعـة وعلو شـأن النبي - صلى الله عليه وسلم - فهو الحكم العدل.

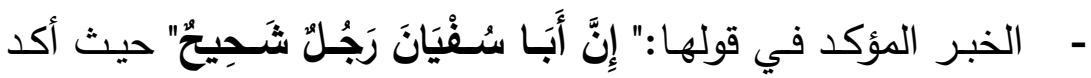
بأكثر من مؤكد دلالـة على شدة بخله، وإذا كان هذا حاله مـع من وجبت

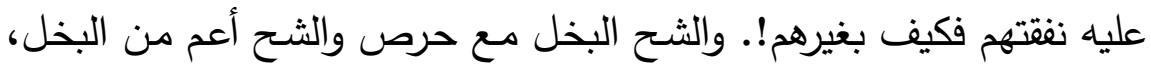
لأن البخل يختص بمنع المال والثح بكل شيء، وقيل: الثح لازم كالطبع،

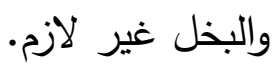
" ولم ترد هند وصف أبي سفيان بالثتح في جميع أحواله وإنما وصفت حالها معـه وأنه كان يقتر عليها وعلى أولادها وهذا لا يستلزم البخل مطلقا

فإن كثيراً من الرؤساء يفعل ذلك مع أهله ويؤثر الأجانب استئلافاً لهم. (')

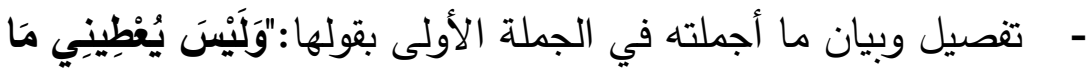

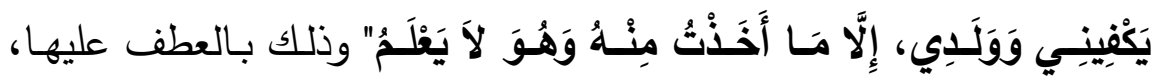
ومضارعية الصيغة تدل على تجدد واستمرار ذلك منه، فلا يعطيها ما يكفيها وولدها، واستثنت من ذلك حالة واحدة والتي هي موضـع سؤالها وهي أخذها من ماله في حالة عدم علمه. وأسـلوب الحديث أسلوب إنثـائي مـوجز ، حيث بني الحديث على جملـة واحدة لا تصل إلى تمـام معناهـا إلا بآخر حرف فيها؛ وكأن النبي صلى الله عليه وسلم - أراد لهذه الأحاديث أن تحفظ وتشيع على الألسنة حتى يمتثلها الناس قولاً وعملاً، فقد ذكر ابن جني - رحمـه الله - أنه: " قيل

1- ينظر فتح الباري:1/9.0. والفروق اللغوية:90؟. لأبي هلال الحسن بن عبد الله بن

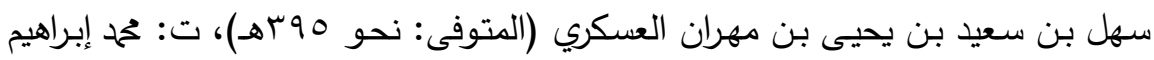
سليم، الناشر : دار العلم والثقافة للنشر والتوزيع، القاهرة .

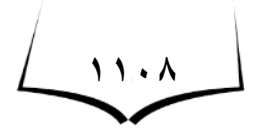




\section{مجلة قطاع كليات اللفة العربية والشعب المناظرة لها العكد [r]]}

لأبى عمرو بن العلاء: أكانت العرب تطيل؟ فقال: نعم لتبلغ، قيل: أفكانت

توجز؟ قال: نعم، ليُحفظ عنها" (')، وقد لفت ابن وهب إلى هذه الغايـة أيضـاً - في حديثه عن المواضـع التي يحسن فيها الإيجاز ، إذ جاء منها: "المواعظ والسنن والوصايا التي يُراد حفظها ونقلها، ولذلك لا ترى في الحديث عن رسول الله - صلى الله عليه وسلم - والأئمـة شيئاً يطول، وإنما يأتي على غاية الاقتصار والاختصار "(ז)، ولكنها على الرغم من وجازتها إلا أنها قامـت بأداء المعنى على خير وجـه، فالنبي - صـلى الله عليه وسلم - لـ يترك لها العنـان في الأخذ حينما أجابها بقوله:"خُـِي" وهذا الأمـر للإِباحة والتعليم، حيث أباح لها الأخذ من ماله بناء على ما ذكرته. قال القرطبي: وهذه الإباحة وإن كانت مطلقة لفظاً لكنها مقيدة معنى كأنه قال:إن صح ما ما ماء ذكرت. وقال غيره: يحتمل أن يكون صلى الله عليه وسلم علم صدقها فيما ذكرت فاستغنى عن التقييد..(ب) وقد بدا ذلك من خلال ما يلي:

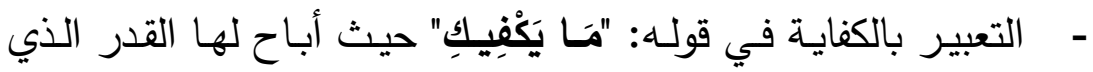
يكون فيه الكفاية دون إسراف وتبذير • - - إضـافة الولد لها في قولـه:"وَوَلَدَّكِ" حيث حدد مـا تأخذه دون علم زوجها عليها وعلى أولادهما فقط. لا يتعدى ذلك إلى أولاده هو، فقد يكون لله أولاد من زوجة أخرى، فهي ليست مطالبة بالأخذ دون علمه للإنفاق عليهم. كما أن فيه إيجازًا بالحذف والتقدير : ويكفي ولدك. وذلك لدلالة ما قبله عليه.

1 - الخصائص لابن جني، /ع/1، الهيئة المصرية العامة للكتاب، القاهر،ط؛.

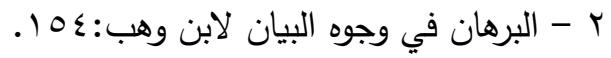

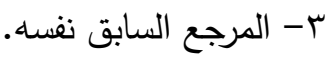


- تقييد الأخذ بالمعروف في قوله:"بِالْمَعْرُوفِ"يدل ذلك على أن النفقة

بقدر الحاجة من غير إسراف وتقتير • وتقييد الأخذ بالمعروف حتى لا يترك لها العنان والعرف سنة جاريـة، والاعتمـاد عليه في الأمور التي ليس فيها

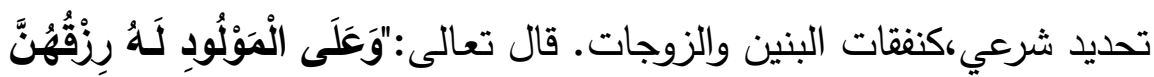

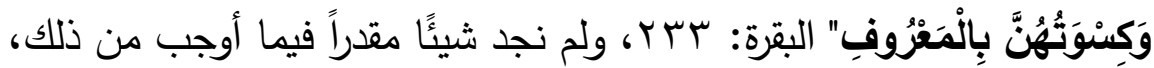

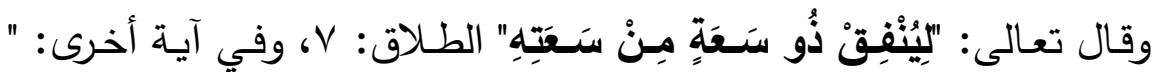

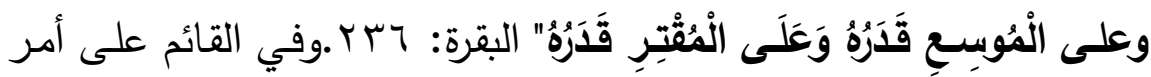

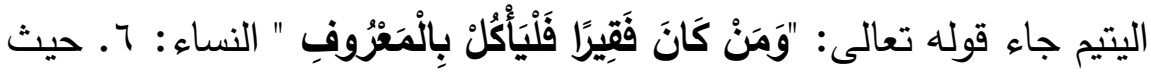
أباح للوصسي الفقير أن يأكل من مـال اليتيم بالمعروف مـا يسد بـه جوعتهـ ويكتسي ما يستر عورته.

وروي عن جَابِرِ بْنِ عَبْدِ اللِهِ- رضي الله عنهما- من خطبة الوداع

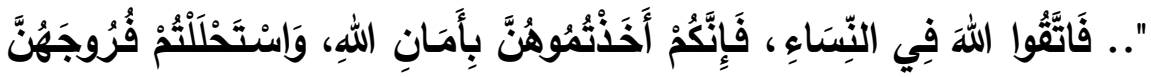

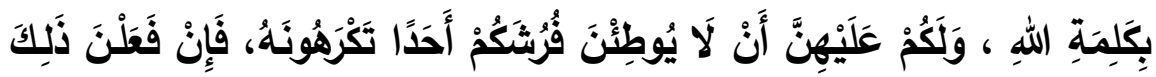

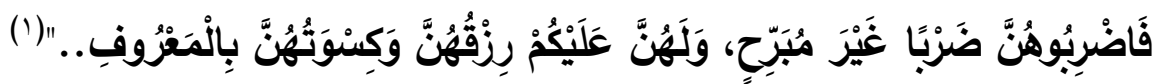
لما قرر إبطال أمر الجاهلية في خطبة الوداع وكان من جملتها منع النساء من حقوقهن وترك إنصافهن أمرهم بمتابعة الثرع في إنصافهن فكأنه

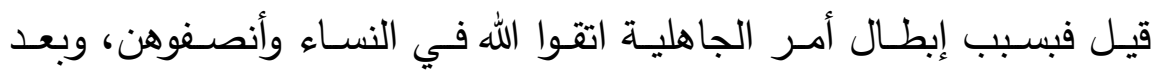
الوصية بهن بين مـا عليهن مـن واجبات ومـا لهـن مـن حقوق وكان مـن حقوقهن على أزواجهن حق النفقة بالمعروف، وقد أعان على تصوير ذلك ملك وبيانه كثير من الألوان البلاغية منها:

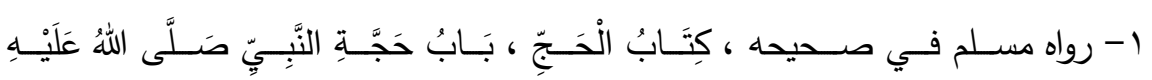

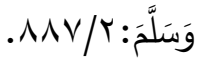




\section{مجلة قطاع كليات اللفة العربية والشعب المناظرة لها العكد [r]]}

- الإرشاد والنصح بالأمر في قوله: "فَاتَّقُوا اللَّة فِي النَّسَاعِ" وفيه الحث على مراعاة حق النساء والوصية بهن وحسن معاشرتهن بالمعروف، ويدخل في عموم هذا كل معاشر للنساء، إلا أن السياق يبين أن الخطاب لـلأزواج بدلالــة مـا بعـده، وذلك بتوفيـة حقـوقهن وحسـن معـاملتهن، والصـبر على إيذائهن، وأن يلين القول لهن، لما فيهن من ضعف واعوجاج بحسب خلقهن، فلا يحمل ذلك الأزواج على القسوة معهن وسوء معاشرتهن.

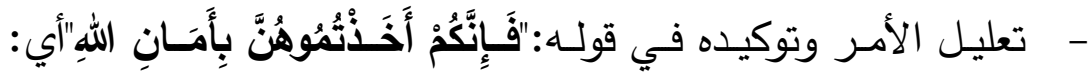
ائتمنكم عليهن فيجب حفظ الأمانـة وصيانتها من الضـياع بمراعاة حقوقها والقيام بمصالحها الدينية والدنيوية، والتعبير بالأخذ فيه معنى الغلبة والتملك

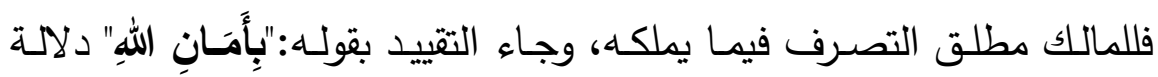
على أن هذا التصرف مقيد بما بيّنه الثرع وحدده من الرفق بهن، والثفقة عليهن. فهن إماء الله، فإذا تزوجتموهن فكأن الله أعطاكموهن بالأمانة، فإذا آذيتموهن بالباطل فكأنكم نقضتم عهد الله، وخنتم أمانته. ( )

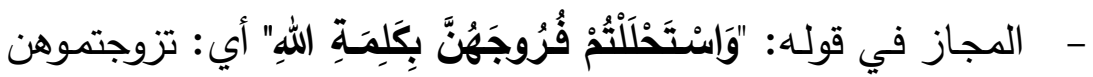
بحكم الله وأمـره، وإذا تزوجتموهن بحكم الله وبـأمر الله فكأنهن بحكمـه، فإذاذ تزوجتموهن بحكم الله فكأنهن مودعات وأمانـات من الله عندكم. وفي معناه

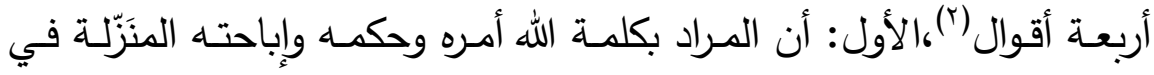

1- ينظر المفاتيح في شرح المصابيح:r/rVq. ، ، للحسين بن محمود بن الحسن، مظهر

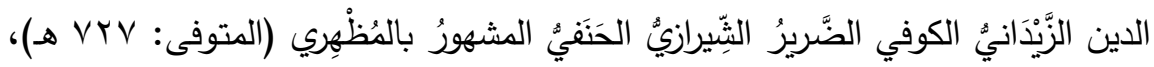

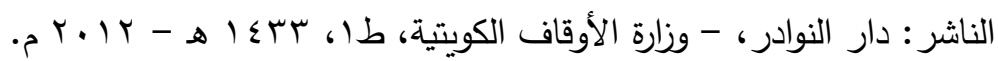

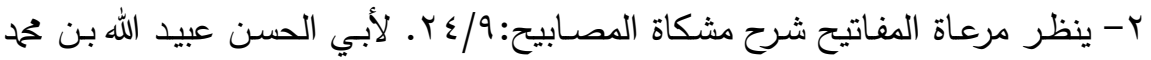
عبد السلام بن خان محمد بن أمسان الله بن حسام الدين الرحماني المباركفوري (المتوفى: $==$ 


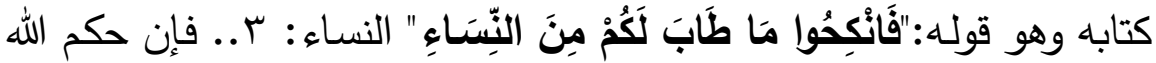
كلامه المتوجه للمحكوم عليه على جهة الاقتضـاء أو التخيير . الثاني: المراد كلمـة التوحيد لا إلـه إلا الله محمد رسـول الله، إذ لا تحلـ مسـلمة لغيـر مسلم.

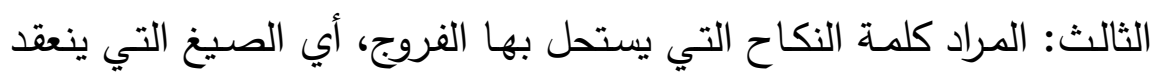
بها النكاح من الإيجـاب والقبول لأن الله تعالى أمر بهـا. الرابع: أن المـراد

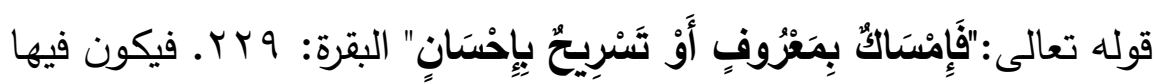
مجاز مرسل، علاقته الجزئية، حيث بين عظم هذه الكلمة ومنزلتها فهي كلمة الله وحكمه وتوحيده والتي بها يكون تحليل المحرم، لما لأهمية الكلمة وبيان خطرها ومـا يترتب عليها من حقوق وواجبات، فاستحلال الفروج إنما كان بكلمـة الله وعهده وحكمـه، فإن نقض العهد فثمّ عقاب الله. وممـا يلحظ في الجمـل الثثلاث تكرار لفظ الجلالـة "اللهِ" لتربيـة المهابـة في قلـوب الرجـال وحثهم على تقوى الله في النساء.

- تقديم ما عليهن من واجبات قبل بيان ما لهن من حقوق في قوله:"

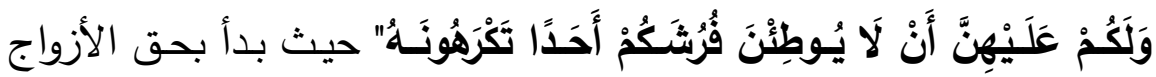

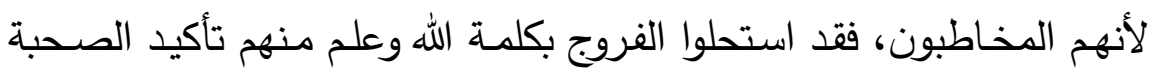
بينهما بهذا الرباط المتين، ولكي تستقيم الحياة بينهما ويكون بينهما السكن والمودة والرحمة كان بيان ما لكل منهما من حقوق وما عليه من واجبات.

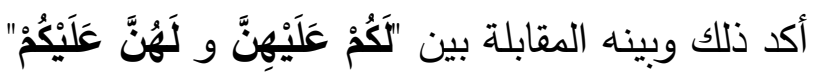

乏 اء أهـ) ، الناشر : إدارة البحوث العلمية والدعوة والإفتاء - الجامعة السلفية - بنارس

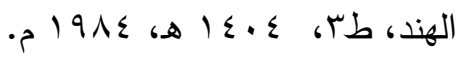




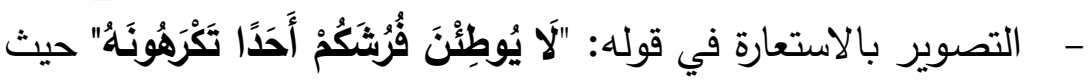

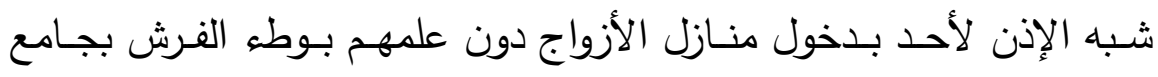

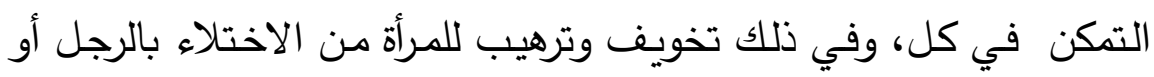

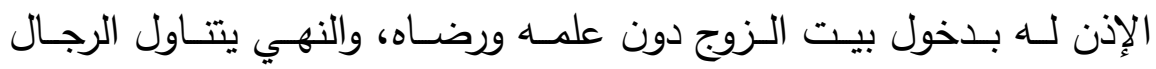

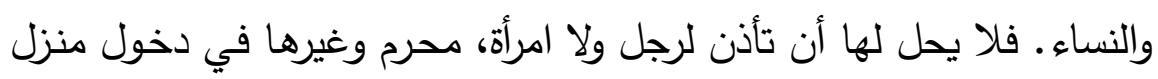

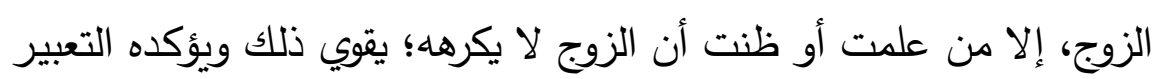

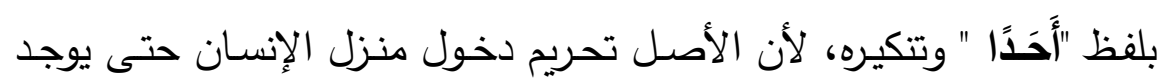

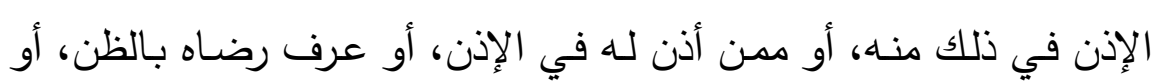

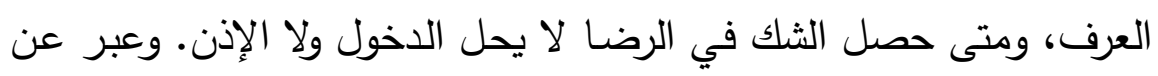

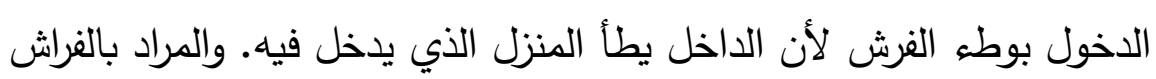
ما هو أعم من فراش النوم فيدخل في ذلك فراش البيت ويدخل في ذلك الك أيضاً

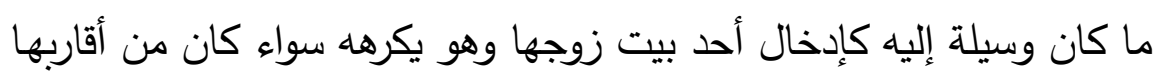

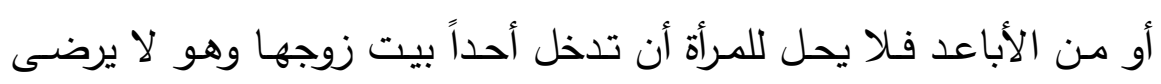

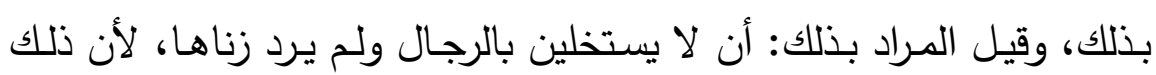

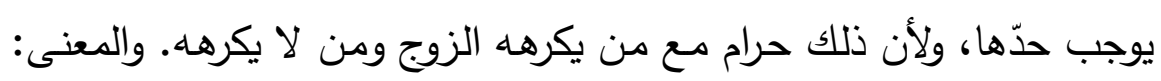

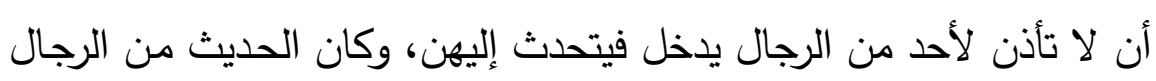

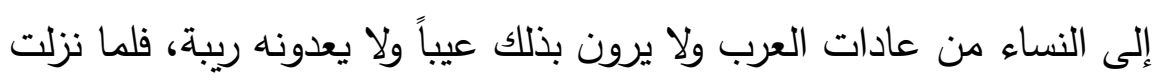

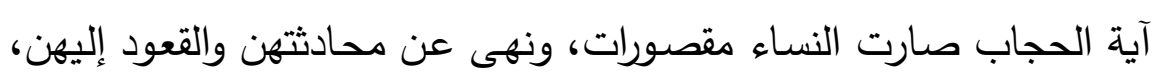

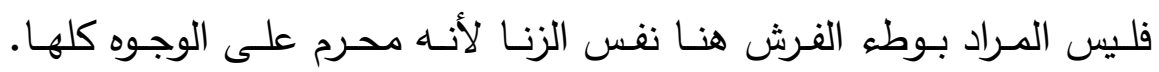

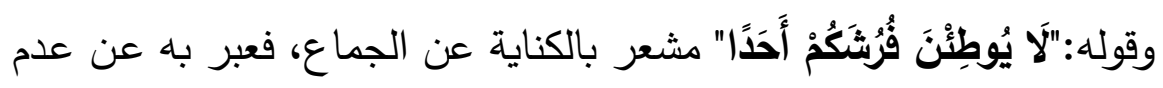


الإذن مطلقـاً تغليظـاً وتثديداً. (') ويحتمـل أن يكون التعبيـر بـه لأن الإذن

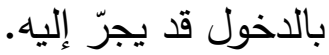

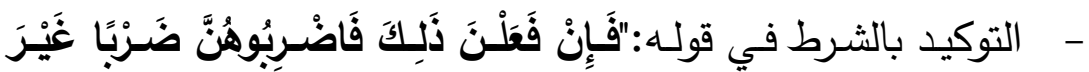

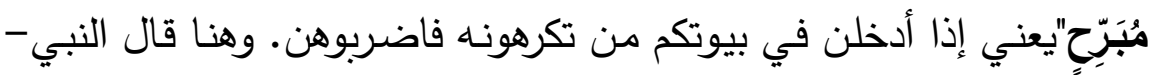
صلى الله عليه وسلم-اضربوهن وفي القرآن الكريم يقول الله تعالى:"قألَّلَّتِي

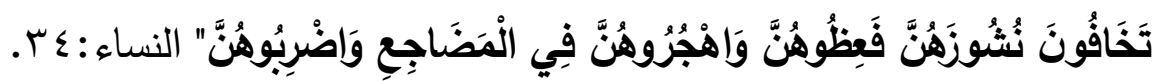

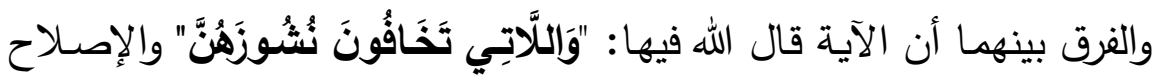

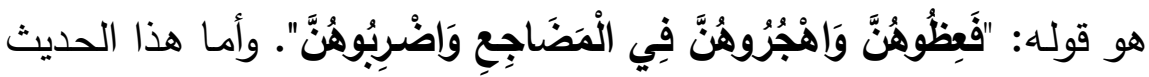

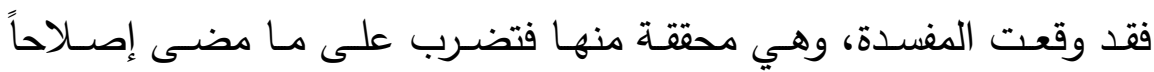

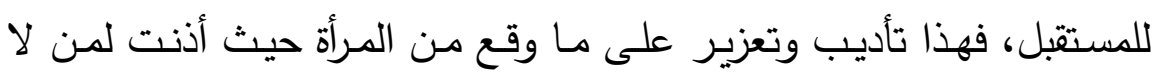

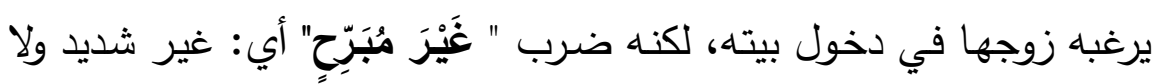

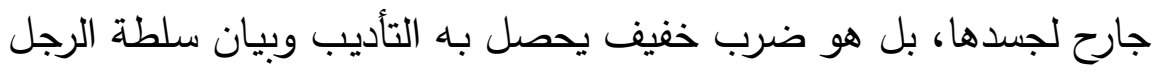

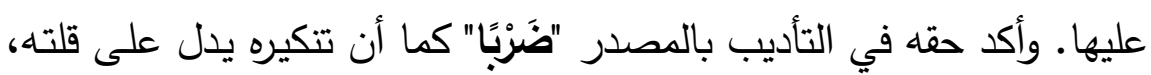

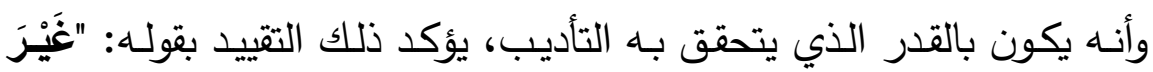

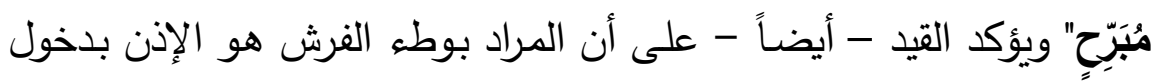

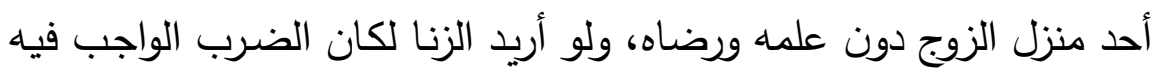

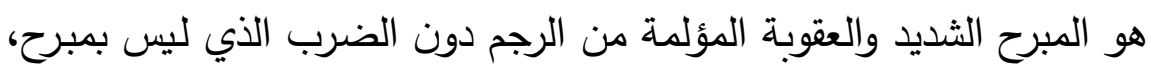

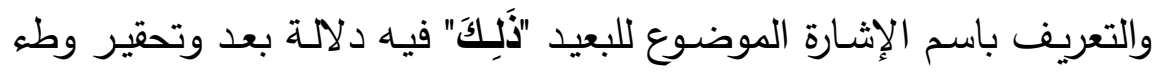

1- 1977.197/ ينظر المرجع السابق نفسه، وشرح الطيبي:1 
فرش الزوج بدون إذنـه وأن الأصل فيه ألا يكون، وإن حدث ذلك فهو قليل

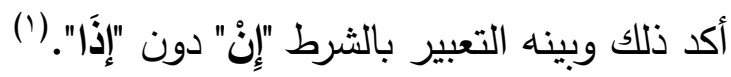

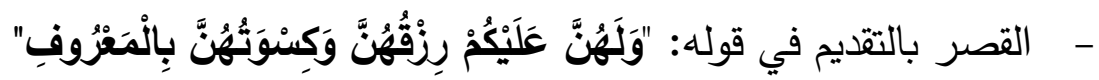
حيث أكد حق الزوجة في النفقة والكسوة ووجوب ذلك على زوجها، فقصر

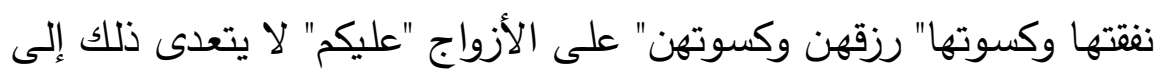
غيرهم من الآباء أو الإخوة، فنفقة الزوجة على زوجها، ولتفاوت الأزواج وكذا

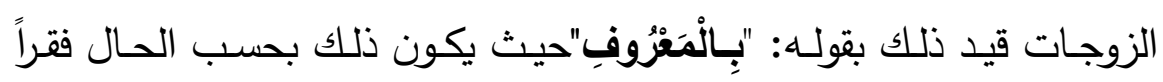
وغنى، وعلى قدر كفايتهن من غير إسراف أو تقتير • والرزق يشمل النفقة والطعام والشراب والكسوة والسكن وغير ذلك، ولذا كان عطف الكسوة على الرزق من باب عطف الخاص على العام للاهتمام بشأن الخاص والعناية بكسوتهن وسترهن والحفاظ عليهن.

\section{الاختصاص بأيام عند الزواج.}

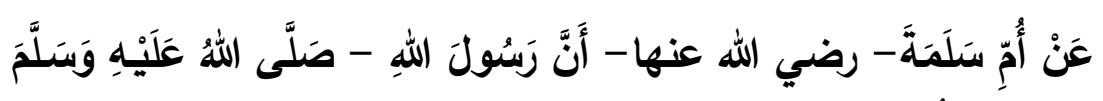

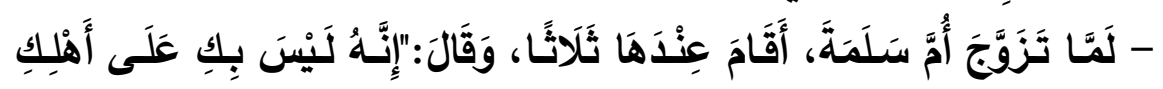

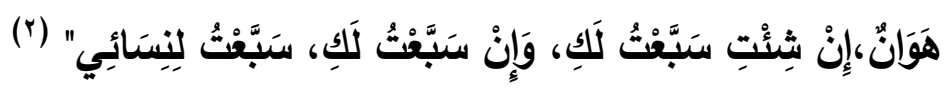
من حق الزوجـة على زوجها أن يختصها بأيام محددة في المبيت وذلك في بدايـة الزواج، فها هي أم سلمة - رضـي الله عنها- لمـا تزوجها 1- ينظر شرح حديث جابر في صفة حجة النبي صلى الله عليه وسلم:0V. لمحمد بن

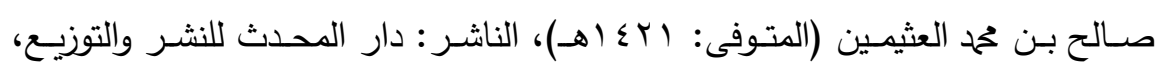

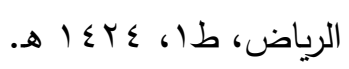

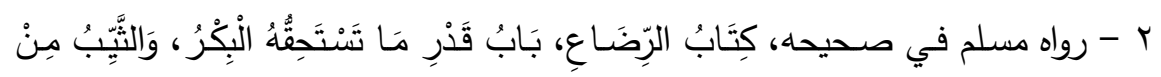

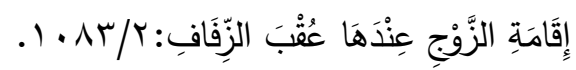


النبي - صلى الله عليه وسلم- خيَّرها، بين أن يقيم عندها سبع ليالٍ، ثم يقيم عند كل واحدة مـن نسائه كذلك، وإن شـاءت اكتفت بـالثلاث، ودار على نسـائه كل واحدة في ليلتها فقط. فمقام الحديث بيـان مـا للزوجـة مـن حق

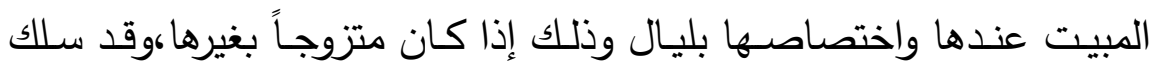
البيان النبوي في بيان ذلك كثيراً من الألوان البلاغية منها: - الالتفات من التكلم إلى الغيبة على رأي السكاكي في قول أم سلمة

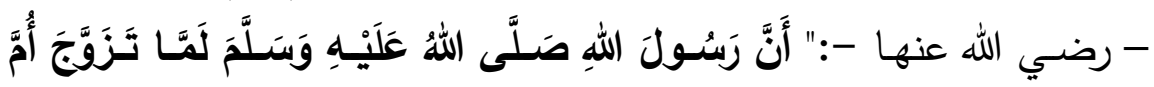

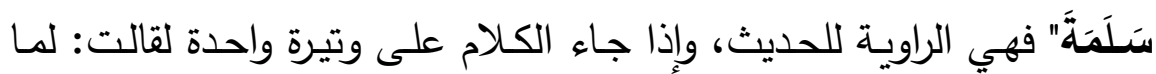

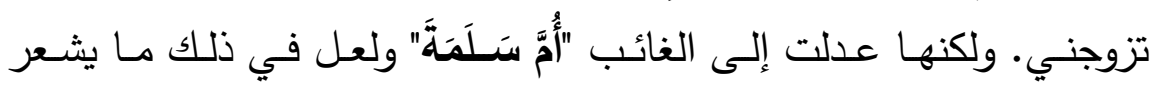
بحيائها وذلك من رجائها طول بقاء النبي - صلى الله عليه وسلم - معها. فلم يكن العرب يلتزمون قسماً بين الزوجات، ولا عدلاً بينهن، بل كان العضل بله منتشرًا، وتعليق الزوجات شائعًا، وكانت الزوجة الجديدة تحظى من زوجها بإقامـة لا حدود لها، فجاء الإسـلام بالقسم والعدل، وكل مـا ميّز بـه الزوجـة الجديدة هو الإقامة عندها ثلاث ليال عتب الزفاف إن كانت ثيبًا، وسبع ليال إن كانت بكرًا. وطبق الرسول الكريم - صلى الله عليه وسلم - هذا القانون على أم سلمة، حيث دخل عليها فأقام عندها ثلاثاً، فلما أصبح، ورأت منـه مظاهر الخروج والاتصراف عنها تعلقت بثيابه، ترجو طول بقائه معها، فقال لها: حقك ثلاث ليال. (') وفيه تهيئة وتمهيد لما سيرد بعد ذلك من حُكم النبي - صلى الله عليه وسلم - وبيان علته، فعندما تزوجها أقام عندها ثلاث ليالٍ.

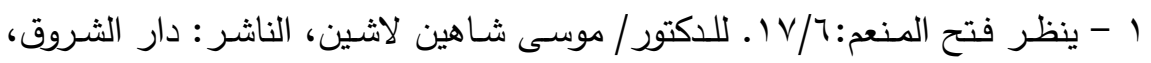

$$
\text { طا، מ }
$$




\section{مجلة قطاع كليات اللفة العريبية والشعب المناظرة لها العكذ[ب]}

- الإيجـاز بالحذف المناسـب للمقـام في قولهـا: " وَقَّالَ" فقيـه حذف

تقديره: ولمـا أراد - صلى الله عليه وسلم - أن يخرج من عندها بعد ثـلاث

أخذت بثوبه وأرادت زيادة مقامه عندها فقال...

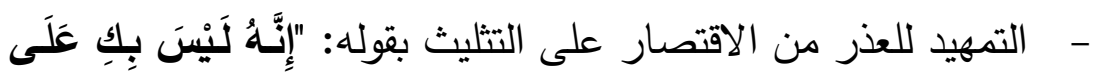
أَهْلِكِ هَوَانْ" حيث جاء مؤكداً بأكثر من مؤكد، وهو كناية عن رفعتها وعلو لأهي

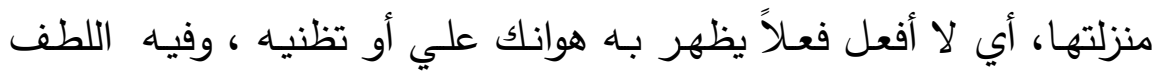
والرفق بمن يخشى منـه كراهة الحق حتى يتبين لله وجـه الحق ، فلا يلحقك هوان ولا يضـيع مـن حقك شـيء بـل تأخذينـه كـاملاً . وقيـل المـراد بأهلهـا قبيلتها، لأن الإعراض عن المرأة وعدم المبالاة بها يدل على عدم المبانه المبالاة

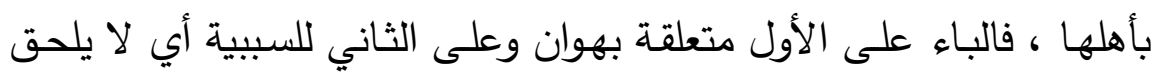
أهلك هوان بسببك ـ وقيل المراد بأهلك هنا نفسه - صلى الله عليه وسلم، أي أي لا أفعل فعلا فيه هوانك عليّ أي ليس في انصرافي عنك إهانة لك. فيكون

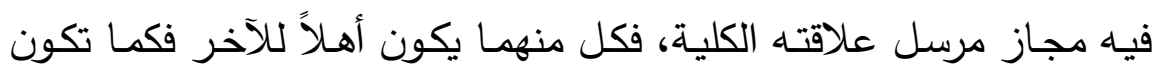

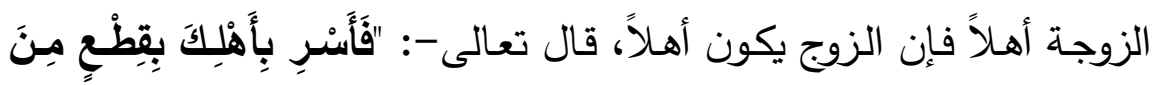

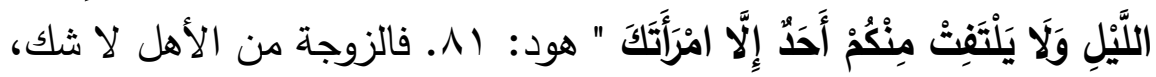
وكذلك الزوج أهل لزوجته. (') وقد دلّ تأكيد الخبر بـأكثر من مؤكد أيضـا على بيان منزلة أم سلمة فهي عزيزة وغالية لديـه وفي قومها، يعاضد ذلك

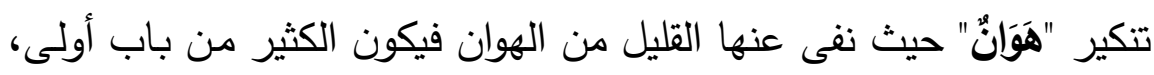

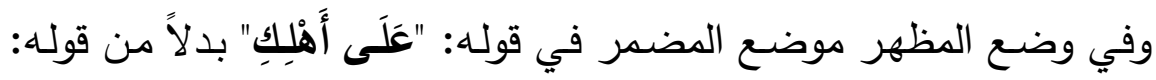

I - ينظر شرح الزرقاني على موطأ مالك:ץ/ץ • r. لمحمد بن عبد الباقي بن يوسف

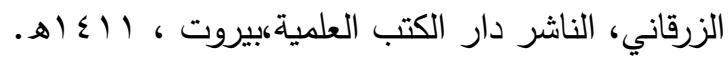


(عَليّ) دلالة أيضاً على شرفها ورفعتها وبيان منزلتها لديه - صلى الله عليه وسلم. فهي منه وهو منها، وهو أهلها وعظِّم بذلك من أهل..

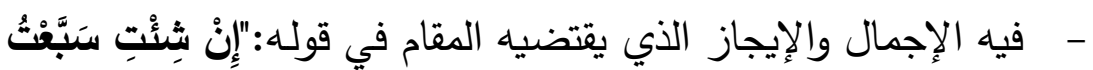

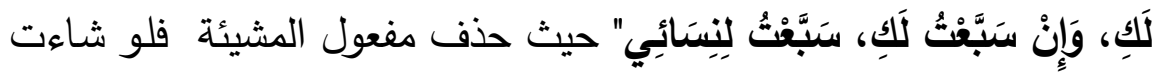
التسبيع سبع لها، وجاء التفصيل والتوضيح بقوله: " سبعت لك" بعد الإجمال والإبهام في قوله: " شئت" فتمكن المعنى أيمـا تمكن، وكذا سيكون لبقيـة نسائه، لأن المقرر أنه إن تزوج الثيب أقام عندها ثلاثاً وإن تزوج البكر أقام عندها سبعاً ثم قسّم. وخصّ البكر بسبع والثيب بثلاث لوجهين. أولاً: قوة الرغبة في البكر غالباً. وفي هذا مراعاة الرجل. وثانياً: استيحاش البكر من الرجال غالبًا فزيد في المدة للاستئناس. وفي هذا مراعاة للمرأة.. فحق البكر أن يقيم عندها سبعاً ثم يقسّم وحق الثيب أن يقيم عندها ثلاثاً ثم يقسّم وأن الثيب إن رغبت أن يستمر عندها سبعاً ثم يقسّم ويقضى لنسائه الأيام الأربعة التي زادها للثيب جاز ذلك. (') والحـديث كنايـة عـن عدل النبـي - صـلـى الله عليـه وسـلم - بـين

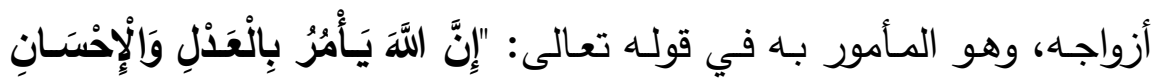

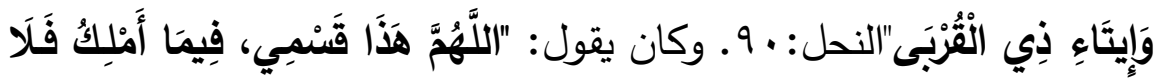

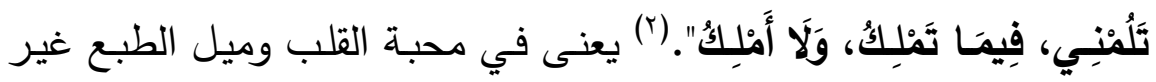

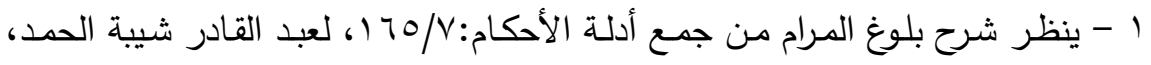

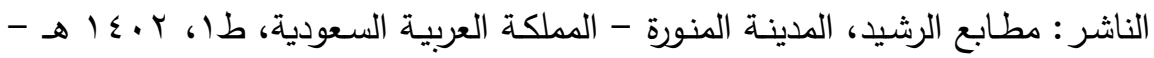

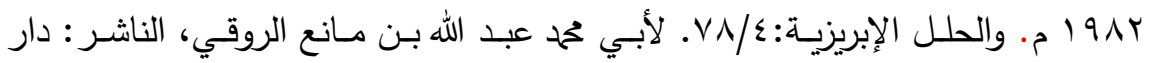

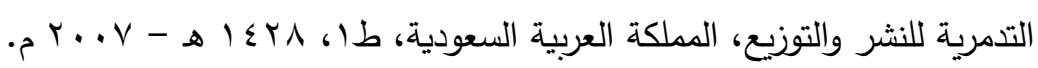

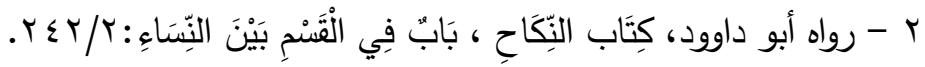




\section{مجلة قطاع كليات اللفة العربية والشعب المناظرة لها العكد [r]]}

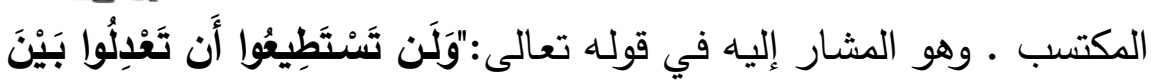

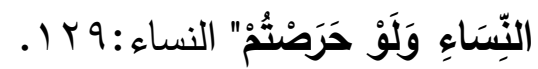

\section{حق الزوجة في إبلاغها بوقت قدوم الزوج بعد غياب}

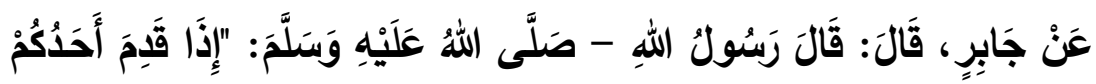

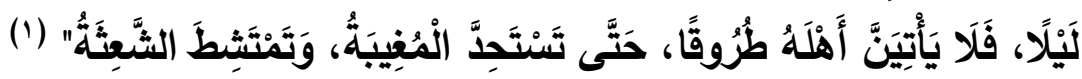
يحرص الإسـلام على الستر وعلى التواد والتحاب، خصوصـاً بين

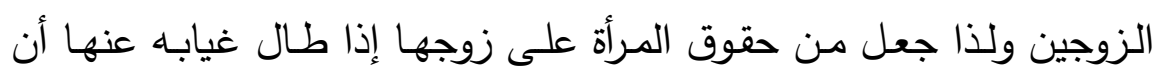
يعطيها الوقت الكافي لتتأهب لله وتستقبله على الصورة التي يحب أن يراها

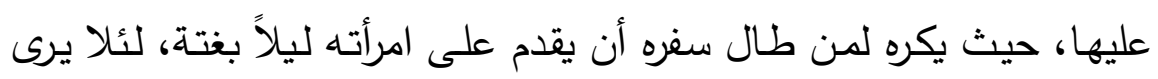

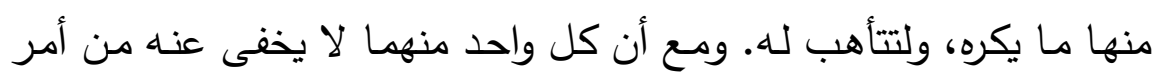

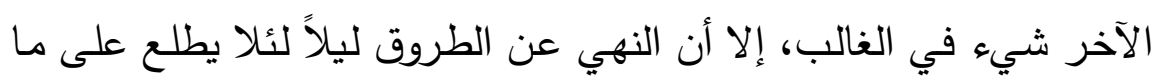
تنفر نفسـه عنه. وقد صـور ذلك البيان النبوي بكثير من الألكوان البلاغية منها:

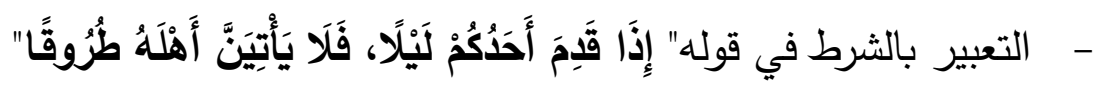
قال أهل اللغة: الطُرُوق بالضم المجيء بالليل من سفر أو من غيره على في

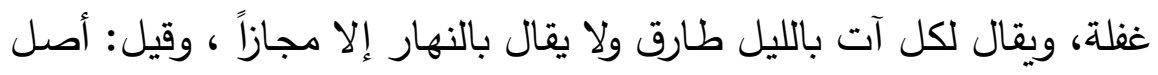

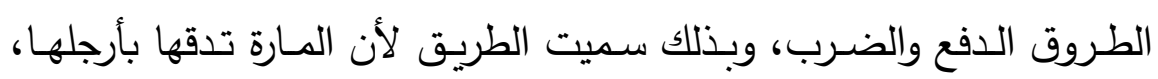

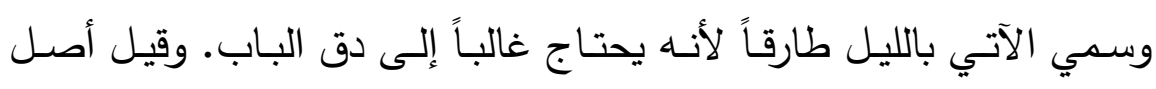
الطروق السكون ومنه أطرق رأسه فلما كان الليل يسكن فيه سمي الآتي فيه طارقاً. وعليـه يكون فيها مجـاز مرسـل، فـالطروق مسن لوازم الإتيان ليلاً،

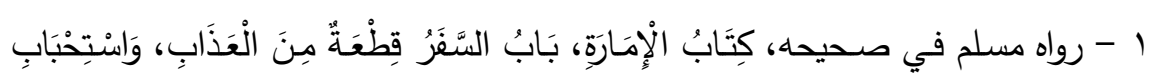

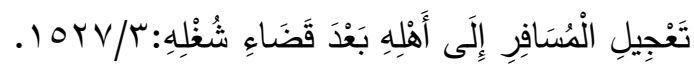


والتعبير بالماضـي "قَدِدمَ" عن المضـارع لبيان تحقق قدومـه بالليل وهذا هو الوقت الذي توجه إليه النهي، يؤكد ذلك ويعاضده مجيء أداة الشرط "إذًَا" دون "إنْْ"، وتتكير "تَيْلَا" للتقليل والمراد به ما بعد وقت العشاء فهذا هو المنهي

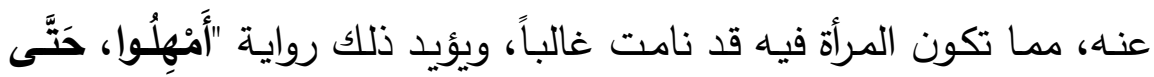
تَنْخُلُوا لَيْلًا"(1)توفيقاً بين الروايات. أو يكون النهي عن الدخول في حال عدم الإعـلام وإلا فجـائز · وكنّى عـن الزوجـة بالأهل وإن كانـت تشـمل الأقـارب

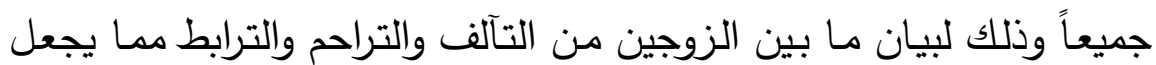

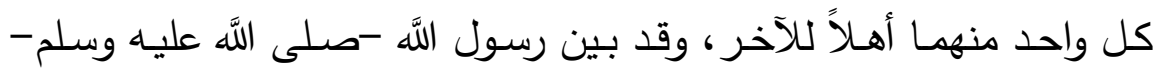
الحكمة في النهي عن الطروق ليلاً وهو عدم مفاجأة المرأة حتى تتهيأ لزوجها بإزالة شعثها والاستعداد لله حتى لا تقع عينه منها على شيء قد ينفره منها. وعلى هذا فإذا أخبر الزوج زوجته بوقت وصوله قبل أن يصل بوقت كاف تتمكن فيه من التهيؤ لله جاز لله أن يدخل عليها بلا حرج في ليل أو نهار

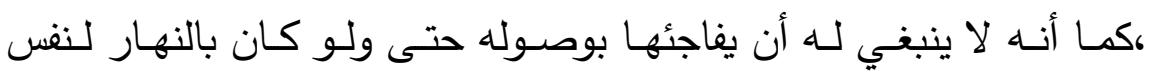
الحكمة التي أشار إليها النبي -صلى اللَّه عليه وسلم. (ب)

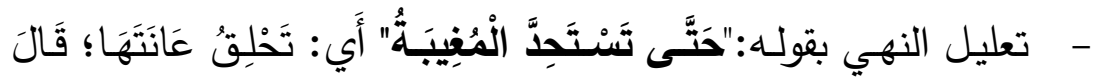

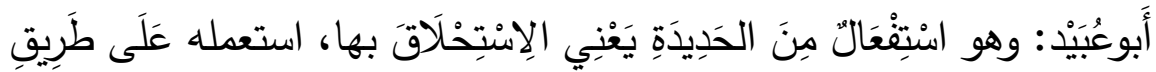

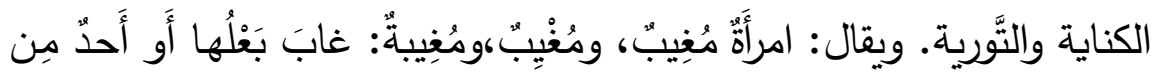

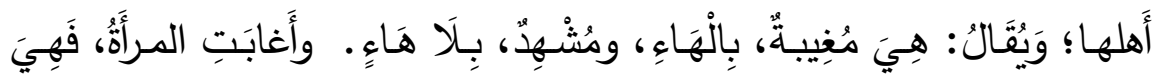

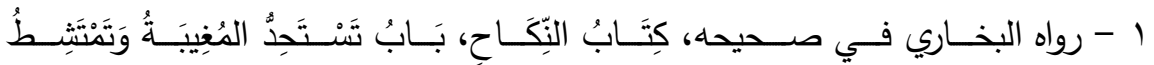

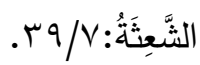

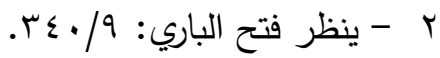




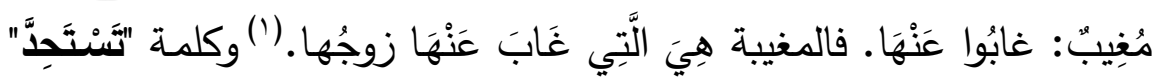
قد أسـهمت بصـيغتها وكثرة حروفها في رسم المعنى، فزيـادة السين والتاء أفادت أن المرأة المغيبة تقصد إلى هذا الفعل وهو الاستحداد، لأنه ونحوه مما تتزين به المرأة، وليس داخلاً في النهي عن تغيير الخلقة بل مأمور به، كما أن اللفظ يرسم نوعية الفعل وهو استخدام الحديد لإزالة الثعر • وجرس الكلمة

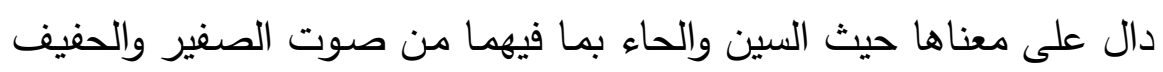
يشبهان صوت الموسي واحتكاكه بالجلد، ثم تأتي الدال الانفجاريـة لتصور

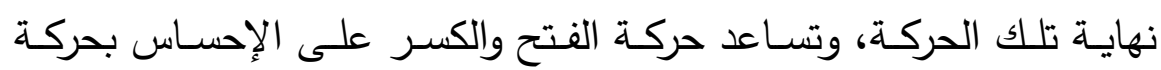

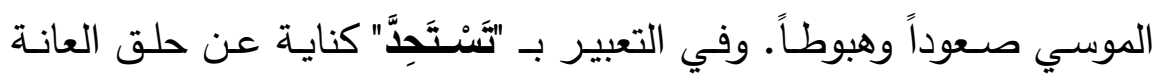
بالموسي وغيره، والتعبير به لأنه المستخدم غالباً، وقد يستخدم غيره في إزالة

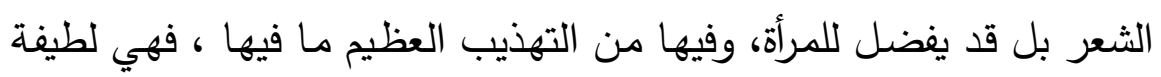
دقيقـة راسـمة مصـورة ، مؤديـة مهذبـة ، فيهـا مـن روعــة التعبيـر وجمـال

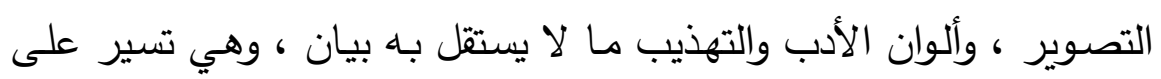

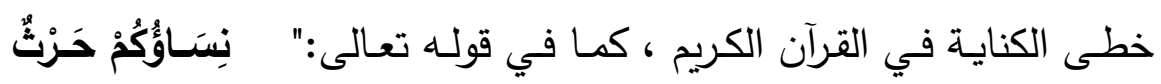

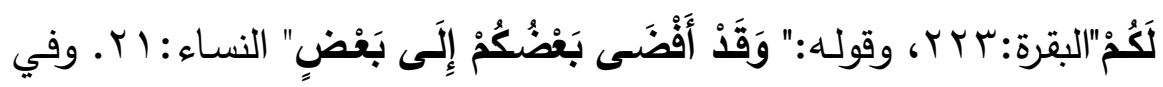
التعبير بهذه اللفظة مشروعية الكناية عما يستحى منه إذا حصل الإفهام بها

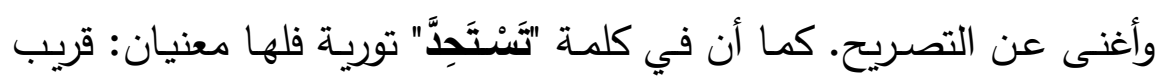
غير مراد وهو استخدام الحديد عموماً، وبعيد وهو المراد وهو حلق العانة،

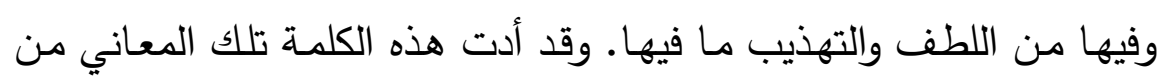

1- - 1 ينظر لسان العرب: (حدد، غيب).

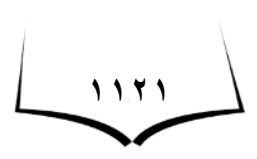


خـلال إيحاءاتهـا وجرسـها، وتهـذيب ولطـف دلالتهـا مـن خــلال الكنايـة

والتورية. (1)

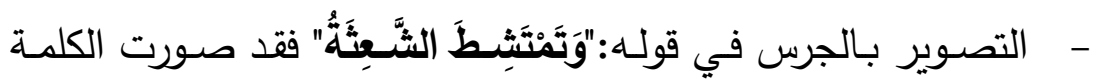
بجرسها وكثرة حروفها "تَمنَتِثَطَ" في رسم عملية إصلاح الشعر الشعث، وكان لصيغة الافتعال الأثر البالغ في إظهار المشقة وقدر الجهد المبذول في هذا الإصلاح أكد ذلك زيادة التاء في "تَمْنَثِطَ" بخلاف ما لو قيل: تمشط، كما أن مضـارعية الصـيغة فيهـا تدل على تجدد واسـتمرار ذلـك لهـا ، وهـذه

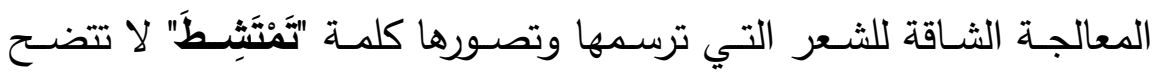
وتكتمل صورتها إلا ببيان شأن الثعر المعالج، وهذا ما تتقله وتصوره كلمة

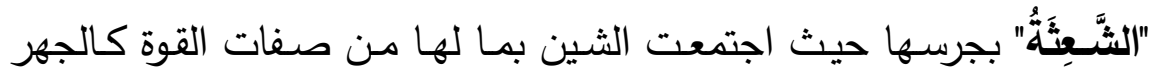
والتثشي والانتشار مع العين بقوتها وحدتها ونصاعتها واحتكاكها والثاء وما فيها من الرخاوة وخروج الهواء، وقد عمل كل ذلك على تصوير حال المرأة الشعثة وهى التي لم تدهن شعرها ولم تمشطه فاغبر وتلبد وتوسخ. وكان من عادات النساء أن تتشعث المرأة إذا سافر زوجها فنترك شعرها دون تمشيط أو دهان.وهي مبتذلة لا تمتشط ولا تدهن ولا تتظف، فلو بغتها زوجها من سفره وهي على تلك الحال استقذرها ونفرت نفسـه عنها، وربمـا يكون ذلك سبب فراقها، فإذا قدم نهارًا سمعت بخبر قدومه فأصلحت من شأنها وتهيأت له فحسنت الحال وأمنت النغرة، فهو يريدها على أجمل صورة وأحسنها، وقد صور جرس الكلمة معناها وذلك مما يشعر بضرورة عنايـة المرأة بثعرها، 


\section{مجلة قطاع كليات اللفة العربية والشعب المناظرة لها العكد [r]]}

وبيان أنه من مظاهر جمالها، وأنـه من أسباب النفرة منها إن أهمل وصـار

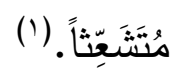

\section{حق الزوجة في الخلع.}

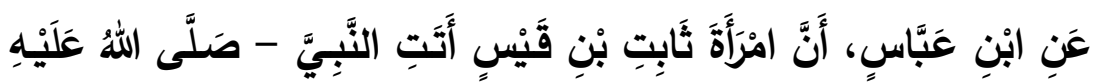

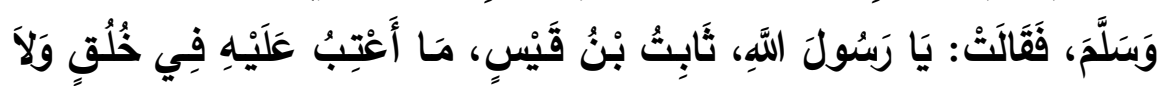

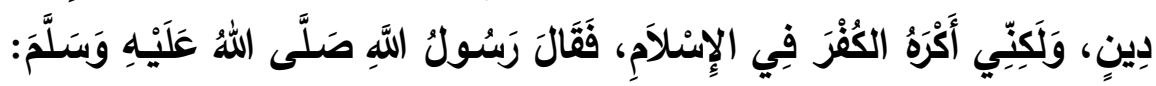

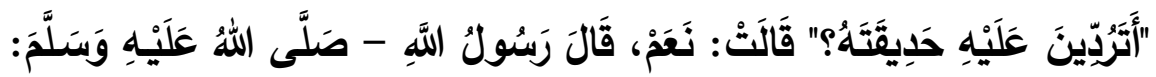

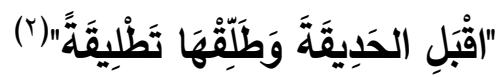

تأمـل هذا الأدب الراقي والبيـان الرائع الذي سـكته تلك الصـحابية الجليلة في التعبير عن مدي حرصها على حسن معاشرتها زوجها ، حيث احتاطت في بدايـة كلامها ووطئت له بهذه المقدمة وتلك التهيئة لمطلوبها بهذا النـاء :" يَـا رَسُـولَ اللَّهِ" دلالـة على رفعـة وشرف المنـادى وبيـان عظم منزلته فهو القاضـي بحكم الله وبمراده. وبقولها في ثابت بن قيس - رضي

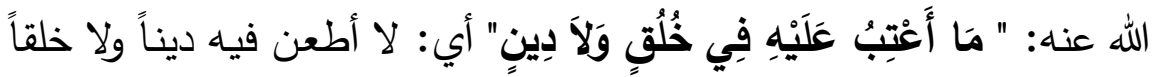
ولا أعيبه بشيء ينقصه من جهة دينه أو خلقه، وتتكير " خُلُقِ وَ دِينٍِ " دالّ على التقليل، فهي لا تعيب عليه أي شيء في الدين أو الخلق، وإن بدا ذلك ولك ولئه

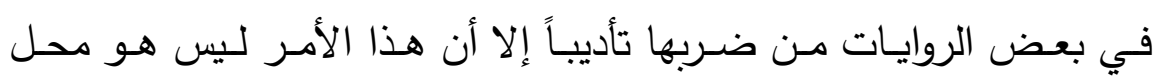

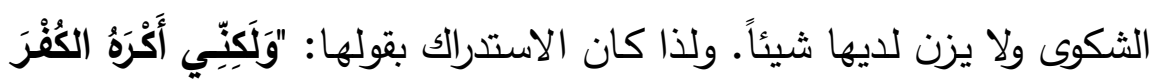

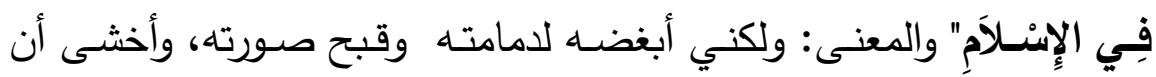

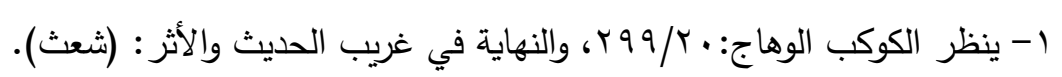

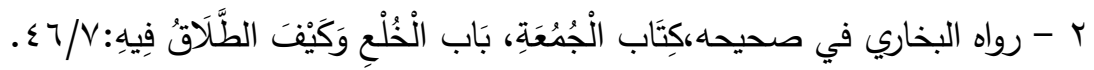

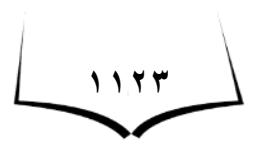


يؤدي بي هذا النفور الطبعي منسه إلى كفران العشير ، والتقصير في حق الزوج، والإسـاءة إليـه، وارتكـاب الأفعـال التي تــافي الإِسـلام مـن الثـقاق

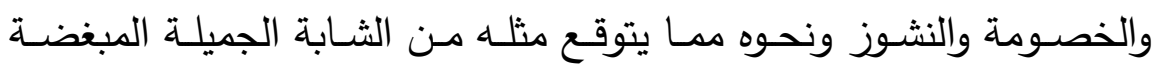

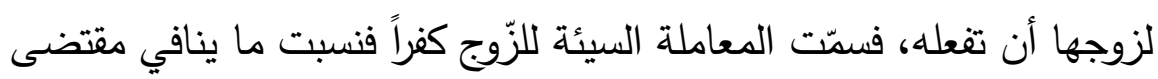
الإسلام باسم ما ينافيه نفسه مبالغة، لما فيه من الاستهانة بالعلاقة الزوجية، وجحود حقوقها المشروعة، وهذا يدخل في كفران العشير ، وينافي ما يقتضيه

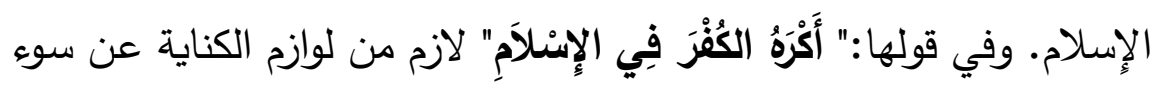

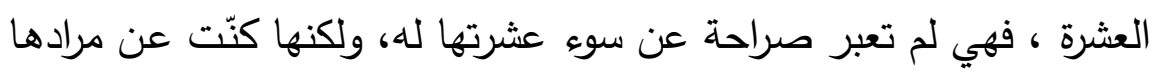

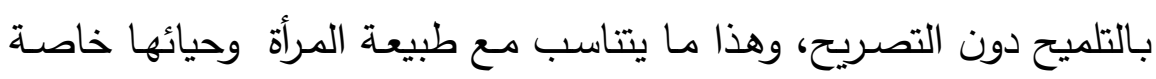
في مثل ما يستحى التصريح باه، ما دام قد فهم المراد منه. ويحتمل أن يكون المراد أنها قد تحملها شدة كراهتها لله على إظهار الكفر لينفسخ نكاحها منه، وهي كانت تعرف أن ذلك حرام لكن خشيت أن تحملها شدة البغض على الوقوع فيه. أو أن يكون ذلك من باب الإيجاز أي:

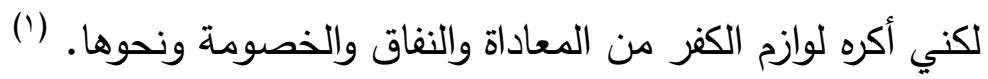
كما أن هذا يوحي بخوفها على نفسها من الوقوع في الفتنة، حيث كانت تقارن بين زوجها وبين بقيـة رفاقـه فقد رُوي قولها: يَـا رَسُسولَ المَّهِ لَا

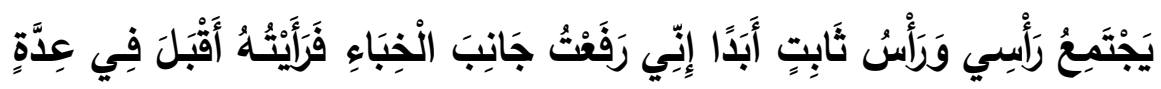

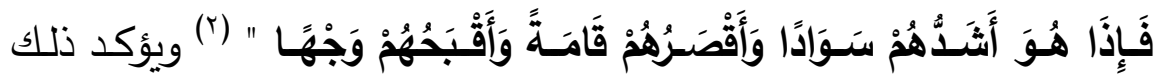

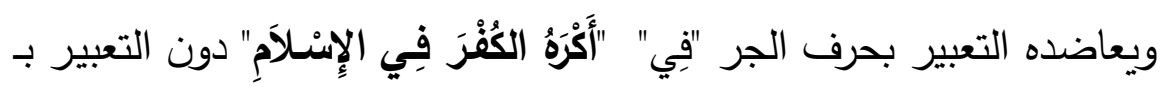

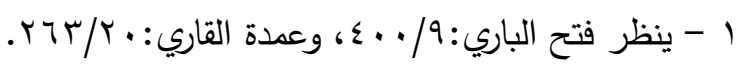

$$
\begin{aligned}
& \text { r - ب - المرجع السابق نفسه. }
\end{aligned}
$$




\section{مجلة قطاع كليات اللفة العربية والشعب المناظرة لها العكد [r]]}

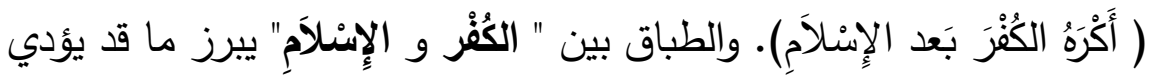
إليه بقاؤها معه - وهي لا ترغبه - من عاقبة غير محمودة.

وبعد هذه المقدمة الموحية الموجزة يأتي حكم النبي - صلى الله عليه

وسلم- المشتمل على كثير من الألوان البلاغية منها:

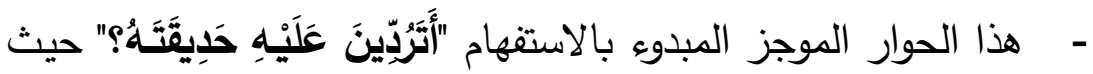

أمهرها ثابت بن قيس. أي: إذا كنت تكرهينه كل هذه الكراهية، وتخشين أن

يؤدي بقاؤك في عصدته إلى أمر مخالف للدين فهل تقتدين منه بردّ حديقته؟

- الإيجاز بالحذف المناسب للمقام في جوابها: " قَالَتْ: نَعَمْ" أي: نعم

أرد عليه حديقته.

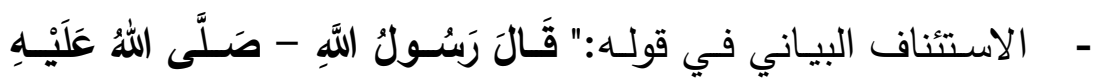

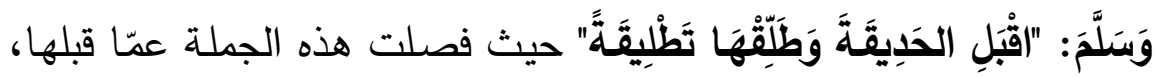
حيث تثير سؤالاً مفاده مـاذا كان ردّ وحكم النبي - صـلى الله عليه وسلم؟ وتصلح هذه الجملة أن تكون جواباً عنه، ولا يخفى ما في حذف السؤال من إيجاز يتطلبه هذا المقام، وفي مثل ذلك يقول الإمام عبد القاهر الجرجاني رحمـه الله: "واعلم أن الذي تـراه في التنزيـل مـن لفظـ "قـال" مفصـولاً غيـر معطوف، هذا هو التقدير فيه، ... جاء على ما يقع في أنفس المخلوقين من السؤال. فلمـا كان في العرف والعـادة فيما بين المخلوقين ..، أخرج الكـلام ذلك المخرج، لأن الناس خوطبوا بما يتعارفونه، وسلك باللفظ معهم المسلك

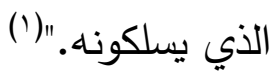

1 - دلائل الإعجاز :•ـr. للإمام عبد القاهر الجرجاني ، ت/محمود حمح شاكر، مطبعة

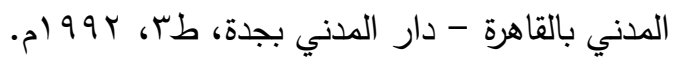




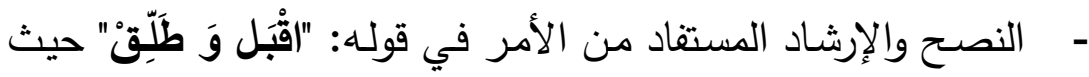

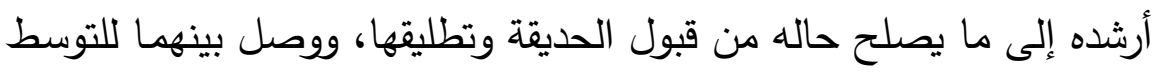

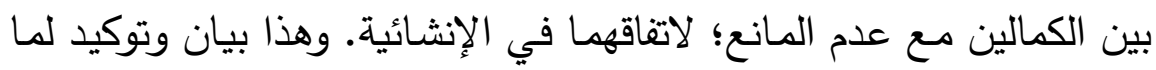

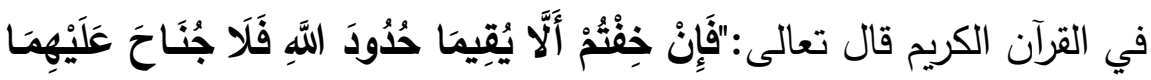

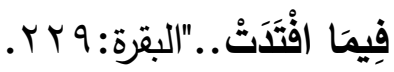

- التعبير بقولهه: " اقُبَل" ومـا يـل عليه من تلطف في الطلب دون

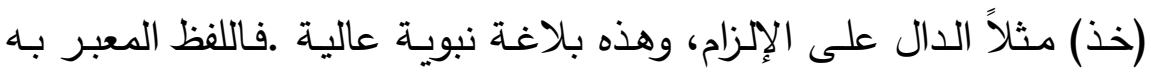

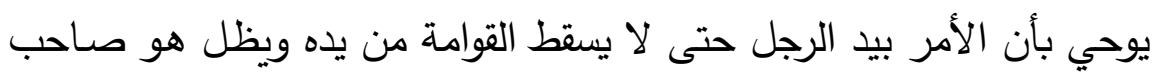

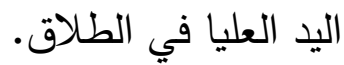

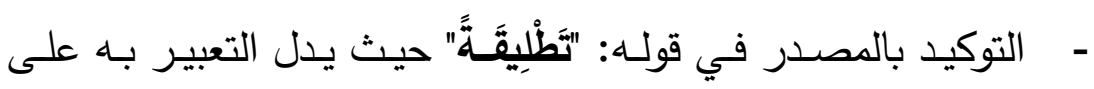

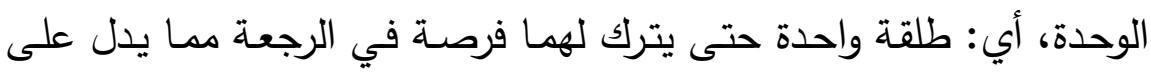

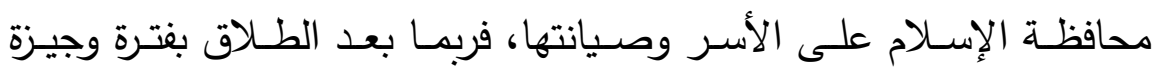

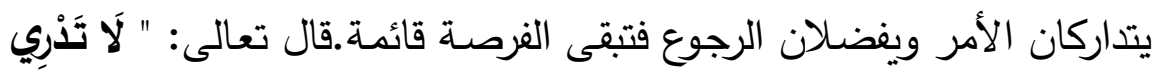

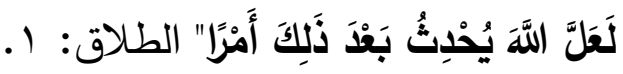
وهذه الروايـة مـع إيجازهـا لم تشر إلى أن النبي - صـلى الله عليه

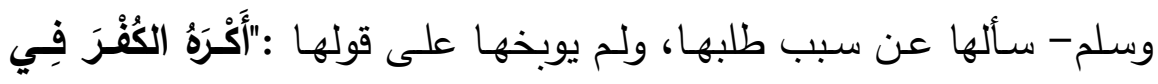

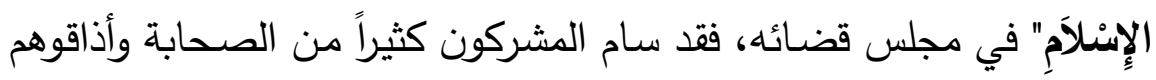

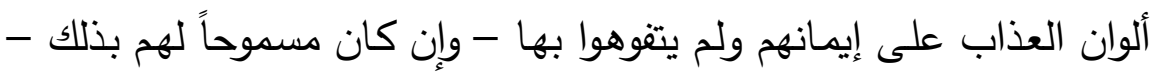

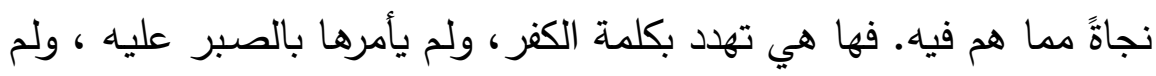

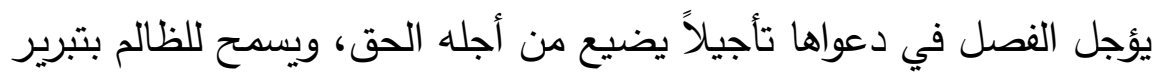

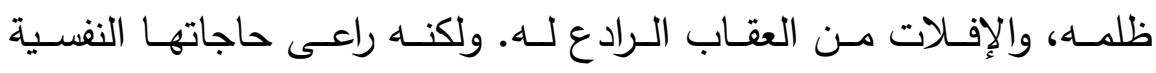

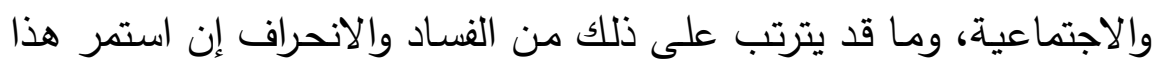




\section{مجلة قطاع كليات اللفة العربية والشعب المناظرة لها العكد [r]]}

الزواج، فهذه العبارة تظهر شدة المعاناة التي تعانيها تلك المرأة تجعلها على الحافة وعلى شفا حفرة، إما الثبات على الدين أو الانقلاب عليه، إما الثبات على ما هي عليه من خلق أو الوقوع في براثن المعصية والرذيلة، ومع كل هذه المعاناة التي تعانيها كانت سرعة الفصل في القضية عقب سؤال واحد

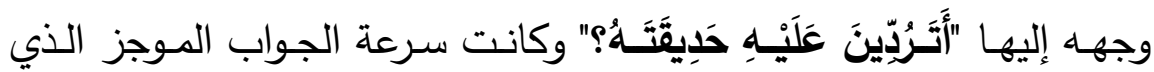

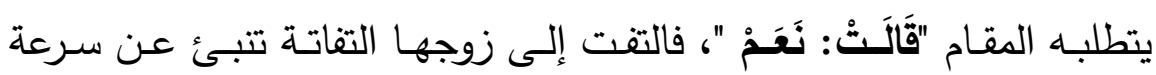

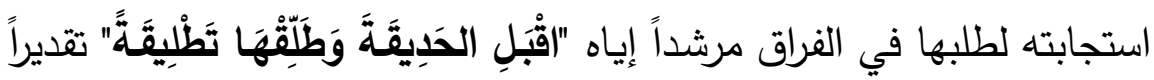
لألمها النفسي وما قد ينتج عن إهمال حاجاتها. 


\section{المبحث الثالث: حقوق الزوجين المشتركة.}

رسم الإسلام حدود العلاقة بين الزوجين وأقام أساسها علي مبادئ

جعلت للزوجين بمقابلها حقوقاً مشتركة، حيث يجب على كل منهما القيام بها حتى تقوى الروابط الأسرية، وتوثق عرى الأخوة والمحبة بين المسلمين، وكان منها:

\section{حفظ السر.}

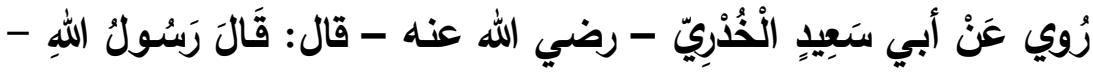

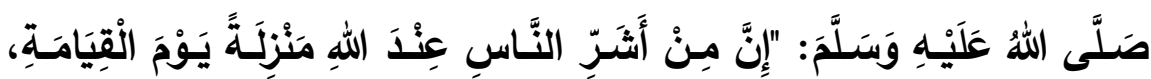

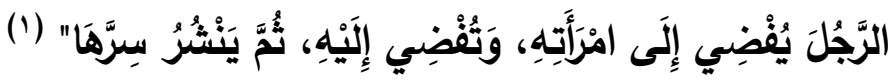

للعلاقات الزوجية في نظر الإسلام قداسة؛ وهي أمانة يجب الحفاظ عليها وسترها، فما يكون من شئون العشرة بين الرجل وامرأته يجب أن يطوى الإنام

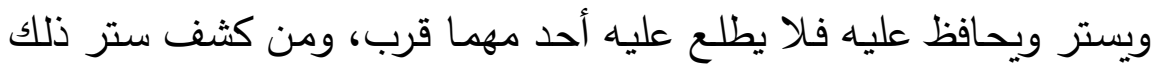

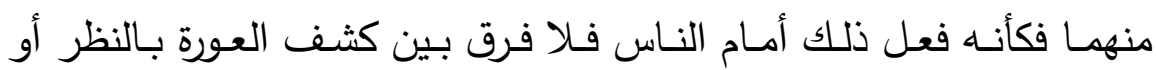
الوصف، وفي ذلك من انتهاك الحرمات وسوء الأدب والإخلال بالمروءة ما فيه وقد صور البيان النبوي عظم هذا الجرم بكثير من الألوان البلاغية منها:

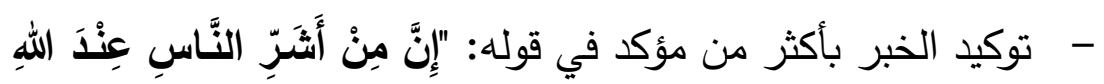

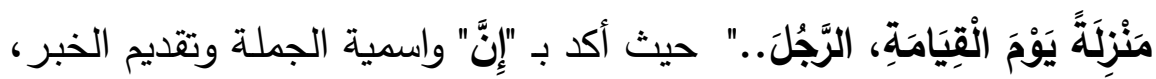

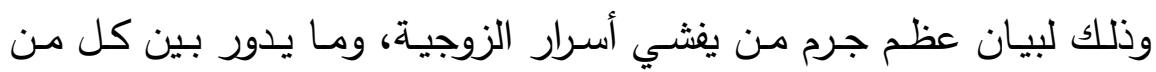

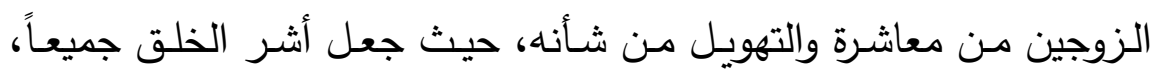

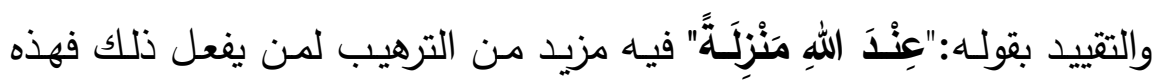

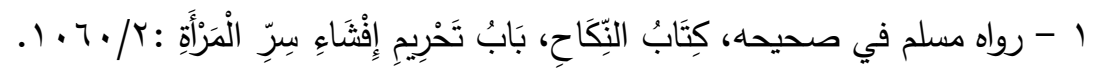

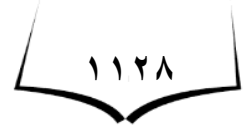


منزلته عند من أمر بالستر والحفاظ على تلك الأمانة فخانها وأفثى سراً قد

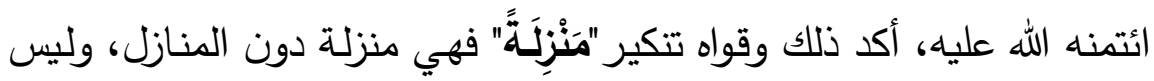

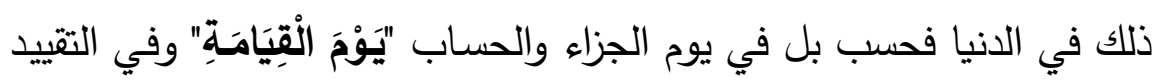
به مزيد من التخويف والترهيب ووعيد شديد لمن ذكر تفاصيل ما يقع بينه وبين امرأته حال الجماع.

- الإيجاز بحذف المضـاف في قوله: "الرَّجُلَ" أي: خيانة رجل يفضي إلي امرأته. وذلك للإسـراع إلى ذكر مـن هو أقدر على ذلك مـن غيـه. والتعريف في الرجل للجنس، فهو يعم ويشمل جنس الرجال، ولم يقصد بـه رجل معين.

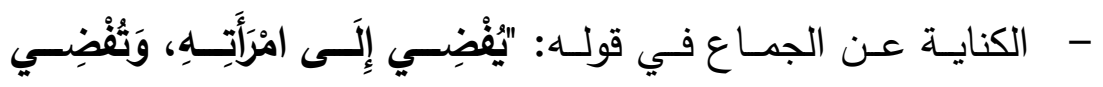
إِلَيْهِ"فالإفضاءُ إلى الثيء : الوصول إليه بالملامسة. والمراد به هنا: الاتصال الجنسي. أو ما يكون بين الزوجين في خلوة.حيث كنى عن الجماع بلفظ الإفضاء لتعليم المؤمنين الأدب الرفيع، فهي كناية لا تخدش الحياء ولا تتفر منها الأذواق، مصورة ومعبرة عن المعنى بأدق تصوير • وقد جاءت الكناية هنا متأثرة بالكناية في القرآن الكريم في أسلوبها وطريقتها وألفاظها ومقامها

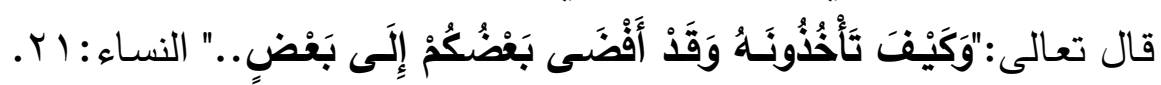

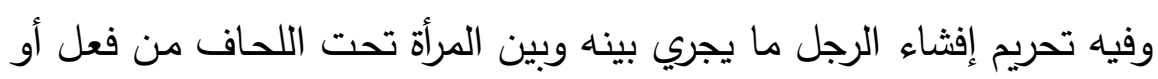

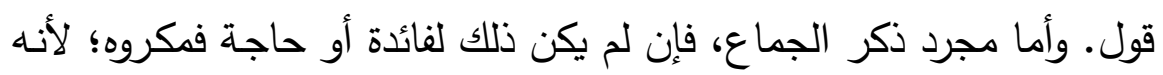
خلاف المروءة، وقد قال - صلى الله عليه وسلم: "مَنْ كَانَ يُؤْمِنُ بِالَّلَهِ وَالَيَوْمِ

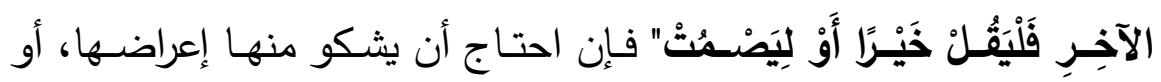


احتاجـت أن تـدعي عليـه العجز عـن الجمـاع أو نحـو ذلك فـلا كراهـة. (') فالنساء ساترات لرجالهن والرجال ساترون لنسائهم كما يستر اللباس العورة،

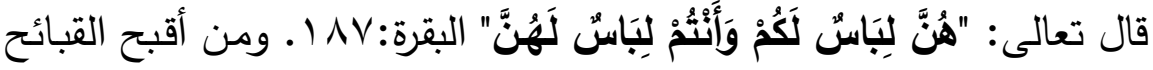
أن يتحول الساتر إلى كاشف فاضـح، ولذا كان من أكثر الناس شراً وعذاباً يوم القيامة الرجل الذي ينشر ما جرى بينه وبين زوجته عند قضـاء شهوتهما من أقوال أو أفعال، مما يخدش الحياء، أو يسيء إلى العفة، فأفعال المرأة

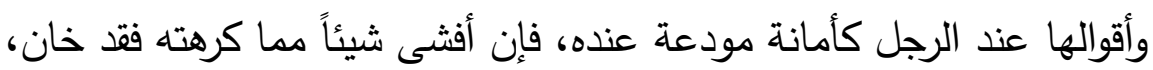
وأفعال الرجل وأقوالـه عند المرأة كأمانة مودعة عندها، فإن أفثت شيئاً مما كرهه، فقد خانت الأمانة، وما أجمل أن يتعامل الزوجان فيما بينهما بالستر ، ليس في الفراش فقط، ولكن في كل شؤون حياتهما، وقد جعل الله الكنايـة مخرجاً عند الحاجة إلى ذكر شيء من ذلك، وجعلت الشريعة ترفع اللسان وصيانته عن التصريح بما لا يليق من مكارم الأخلاق. ولذا يقول المناوي رحمـه الله: "نبـه بهذا الحديث على أن مـن أمـراض النفس المذمومـة شـرعاً التزام قول الحق في كل موطن... ودواؤه معرفـة المواطن التي ينبغـي أن

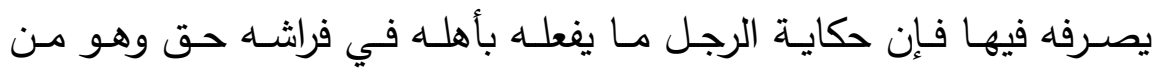
العظائم، والغيبة والنميمة حق وقد عدها بعض الأئمة من الكبائر ، والنصيحة في المهلأ حق وفضيحة، فالعارف يتأمل كيف يصرف الأحكام الشرعية ولا

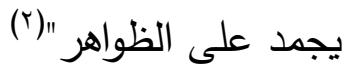

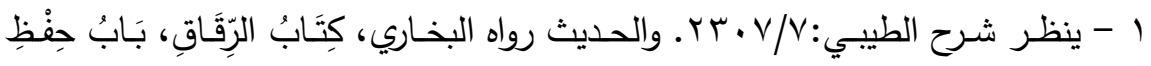

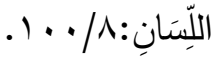

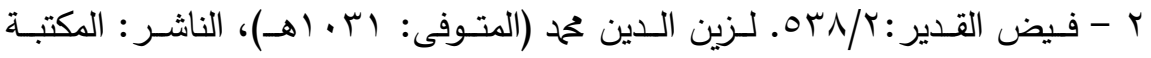

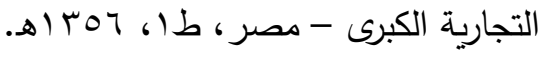




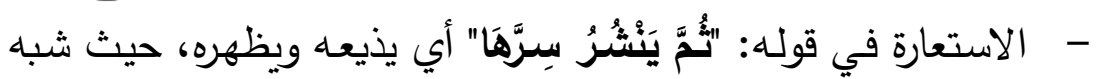
إفثـاء الأسرار الزوجية وذكر عيوب زوجها أو ما يجب ستره من محاسنها بنشر الثوب بجامع الظهور والوضوح في كل، وقد صـورت الاستعارة هذا المعنى وجعلته في صورة السرّ ، والأمانة التي يجب صونها ولهي والحفاظ عليها، فأفعال كل من الزوجين وأقوالهما أمانة مودعة عند الآخر فمن أفثى منهما مـا كرهـه الآخر وأشـاعه فقد خانه، والتعبير بـ "يَتْشُرُ دون دون يذكر أو يظهر

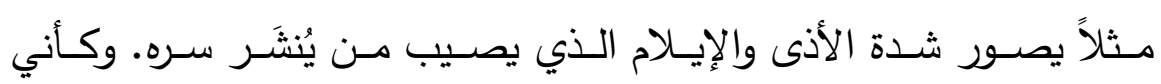

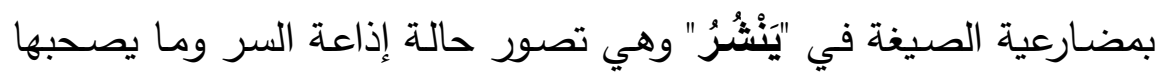
من الإيذاء الثديد والإيلام المتجدد.

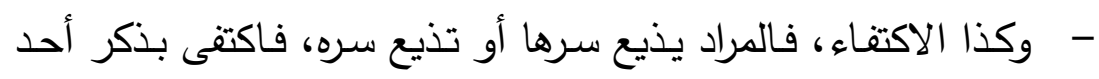

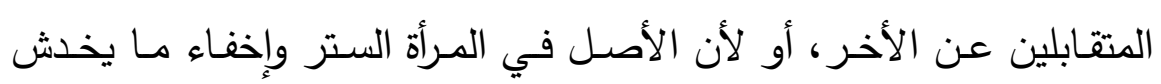
الحياء، وهي لحيائها يقلّ منها وقوع ذلك، بخـلاف الرجل الذي يتوقع منـهـ حصوله.. ومقصود هذا الحديث هو أن الرجل له مـع أهله خلوة وحالة يقبح ذكرها والتحدث بها، وتحمل الغيرة على سترها ويلزم من كشفها عارٌ عند أهل هون

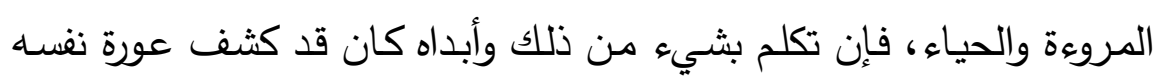
وزوجته إذ لا فرق بين كثفها للعيان وكثفها للأسماع والآذان إذ كل واحد منهما يحصل بـه الاطلاع على العورة ولذلك قال صلى الله عليه وسلم: "لَالَ

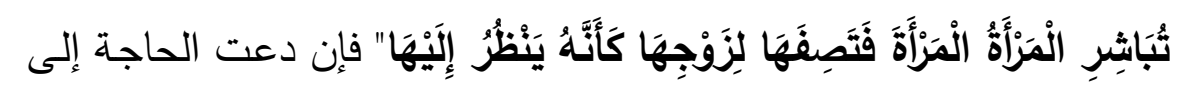

ذكر شيء من ذلك فليذكره مبهماً غير معين بحسب الحاجة والضرورة. (')

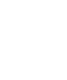

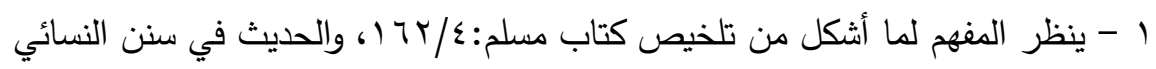

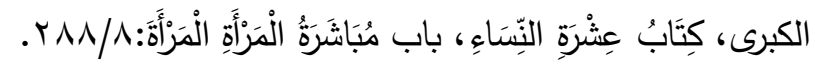

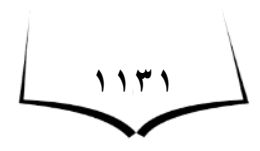




\section{الوفاء بالشروط .}

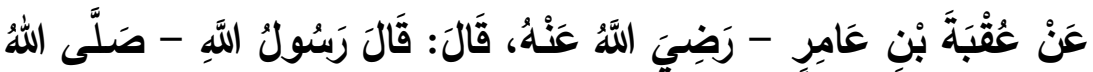

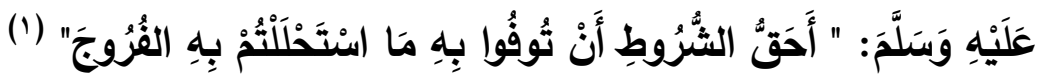

لكل واحد من الزوجين مقاصد وأغراض في إقدامه على الزواج، ولذا

يشترط على صـاحبه شروطاً ليتمكك بها ويطلب تنفيذها، فشروط النكاح

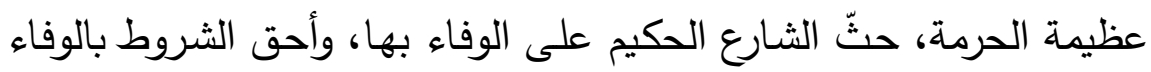

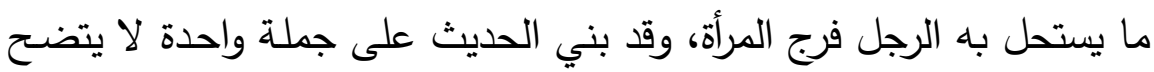
معناها إلا بمنتهاها، والإيجاز شأن بيانه - صلى الله عليه وسلم - ومقام

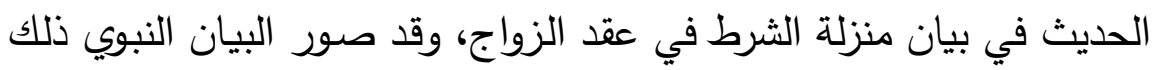

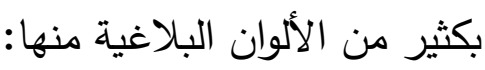

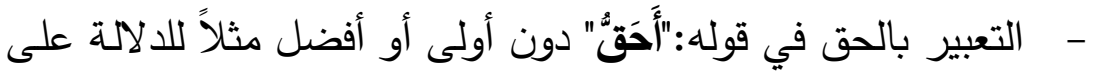
أن هذا حق واجب ومؤكد لا تفريط فيه ويأثم تاركه. دلّ على تحقيقه أيضاً

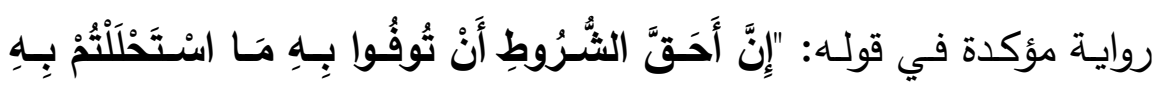

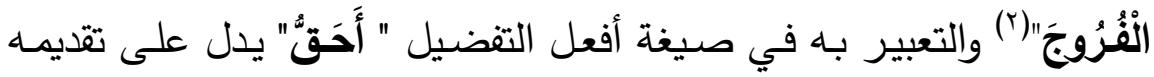

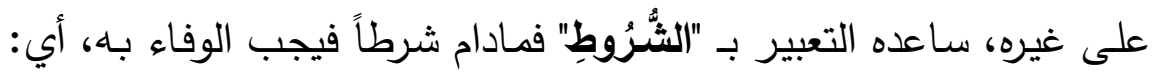

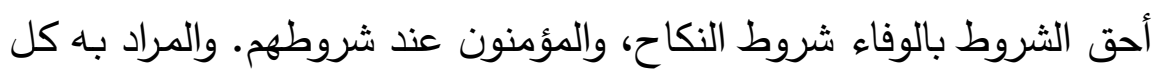

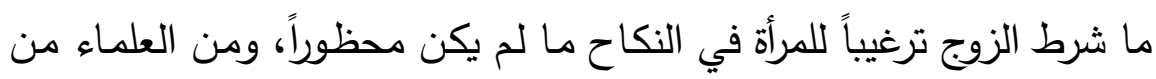

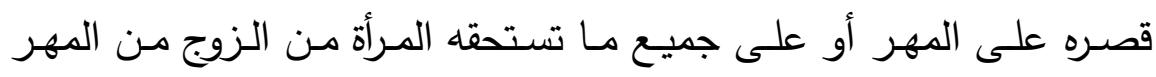

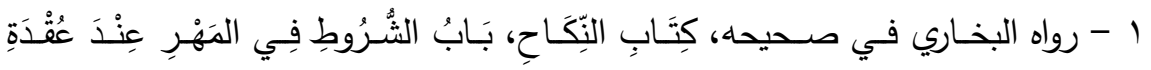

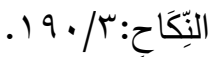

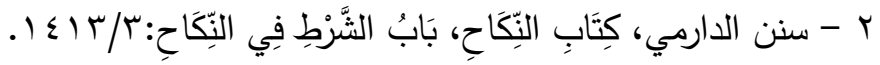

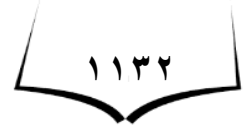




\section{مجلة قطاع كليات اللفة العربية والشعب المناظرة لها العكد [r]]}

والنفقة وحسن المعاشرة ونحوها، قال الثافعي: وأكثر العلماء بأن هذا محمول على شـروط لا تنافي مقتضسى النكاح بـل تكون مـن مقتضـياته ومقاصـده كاشتراط العشرة بالمعروف والإنفاق عليها وكسوتها وسكناها بالمعروف وأنه لا يقصر في شـيء من حقوقها ويقسم لها كغيرها ونحو ذلك، وأمسا شرط يخالف مقتضاه كشرط أن لا يقسم لها، ولا ينفق عليها، ولا يسافر بها ونحو

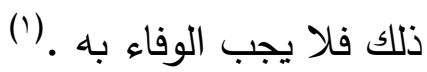
- - التعبير بـ "أن" والفعل "تُوفُوا" دون المصدر (توفية) دلالة على أن هذه الحكم متجدد ومستمر فالتوفية بالثروط متجددة ومستمرة لكل شرط أخذه على نفسـه مـا دام من مقتضـى الزواج ومقاصده، بخـلاف التعبير بالمصدر فيتحقق بالامتثال مرة واحدة.

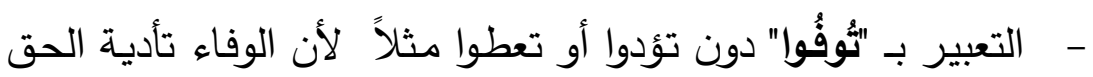

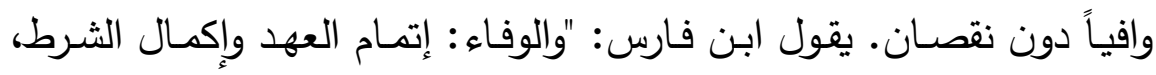

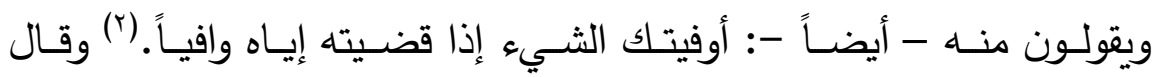
الجوهري: الوفاء ضد الغدر ، يقال: وَفَىى بعهده وأوفىى بمعنى، ووَفَىى الثَيء

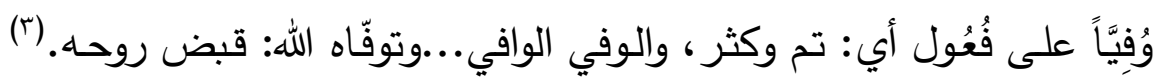

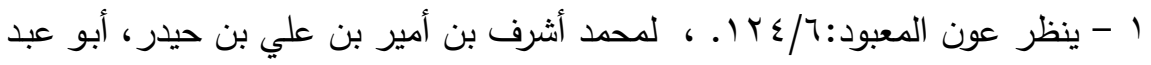

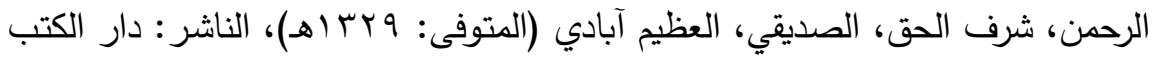

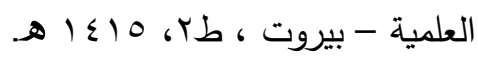
r - مقـاييس اللغـة :مـادة "وفىى" لأبسى الحسين أحمد بـن فـارس،ط دار إحياء الكتاب العربي. r - الصحاح : " وفى ". لإسماعيل بن حماد الجوهري، تح/أحمد عبد الغفور ، القاهرة، .01914 
وقال الراغب: وتوفية الثيء: بذله وافياً، واستيفاؤه تتاوله وافياً، وقد عبر عن النوم والمـوت بالتوفي.(') فالمـادة تدور حول الإتمـام والإكمـال. ولذا يقول الجـاحظ: الوفـاء: هو الصـبر على مـا يبذلّه الإنسـان مـن نفسـه ويرهنـه بـه

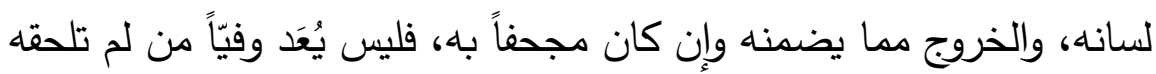
بوفائه أذيـة وإن قلت، وكلمـا أضـر بـه الدخول تحت مـا حكم بـه على نفسـهـ كان ذلك أبلغ في الوفاء.(†) أي أن الإنسان يصبر على أداء ما يعد بـه غيره ويبذله من تلقاء نفسه، ويرهنه به لسانه حتى وإن أضرّ بـه ذلك. والوفاء هو ذلك الخلق الرفيع والقيمـة الإنسـانية والأخلاقية العظيمـة، فهو يرسي دعائم الثقة في الأفراد وخاصسة بين الزوجين. وتقييد التوفية بالجار والمجرور "بِهِهِ" إثارة إلى ترتب الوفاء على ما ألزم به نفسه من الثروط.

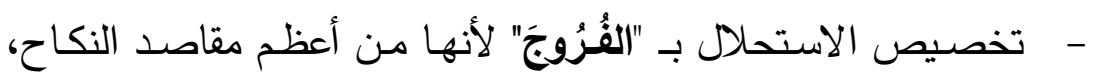
وهو أغلى مـا تملكه المرأة وتحرص على المحافظة عليه، أمسا وقد مكنت الزوج منه فلا يليق له أن ينقض ويخل بما اشترطاه وهذا أبلغ في التنفير من

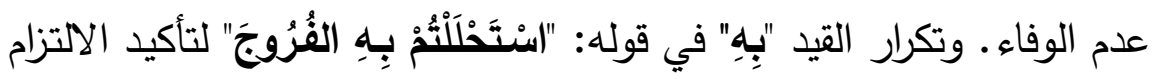
بالوفاء بالشروط التي تثترط في النكاح فهي شروط صحيحة واجبة التنفيذ.

\section{الهق في الاستـمتاع}

عَنْ جَابِرِ بْنِ عَبْدِ اللَّهِ رَضِيَ اللَّهُ عَنْهُهَا، قَالَ: هَلَكَ أَبِي وَتَرَلَكَ سَبْعَ بَنَاتِ

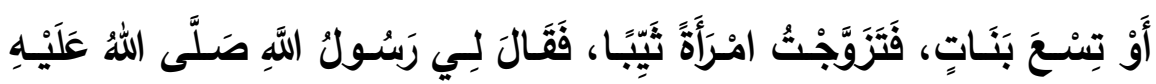

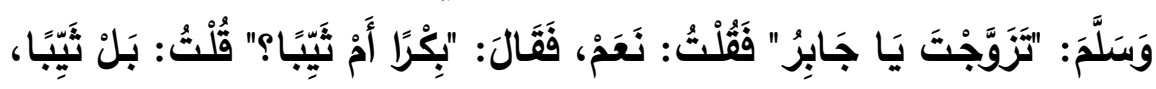

1 - المفردات في غريب القرآن: مادة "وفى" للراغب الأصفهاني، ط. دار المعرفـة -

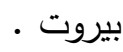
r - تهذيب الأخلاق: ع ب ، لابن مسكويه، ط دار الكتب العلمية، بيروت. 


\section{مجلة قطاع كليات اللفة العربية والشعب المناظرة لها العكد [r]]}

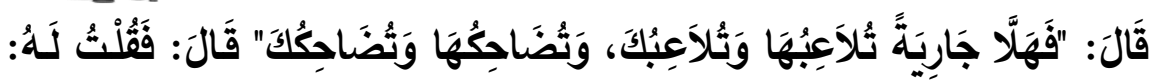

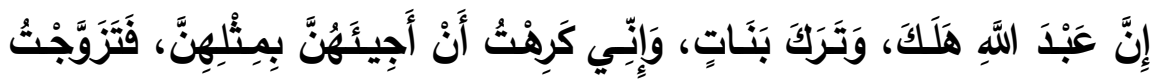

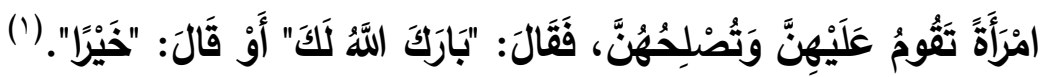

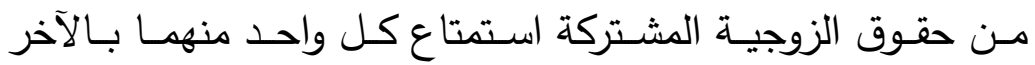

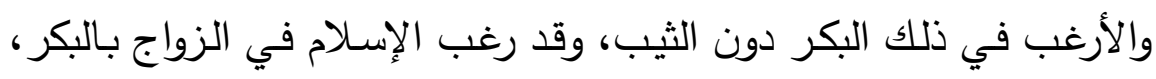

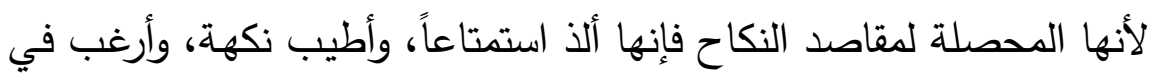

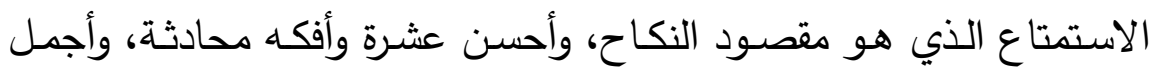

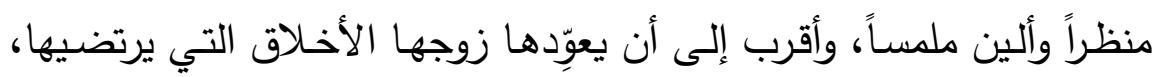

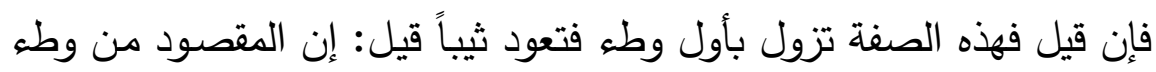

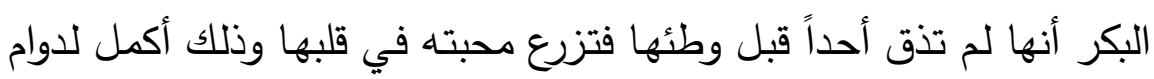

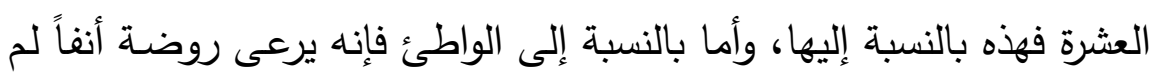

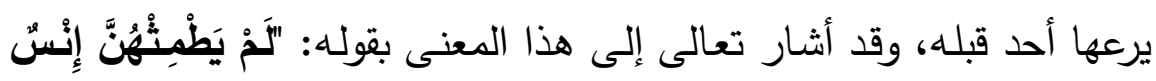

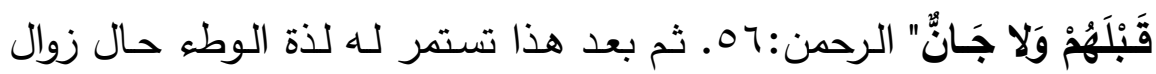

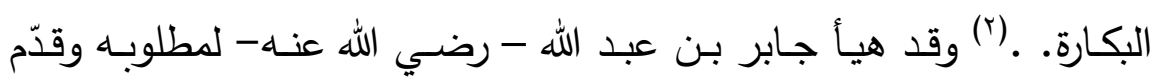

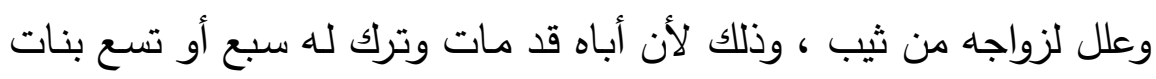
إخوة لـه، بهذا الحوار الموجز الذي دار بينه وبين النبي - صلئ الله عليه

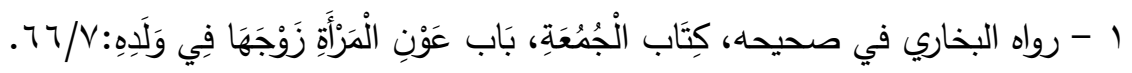

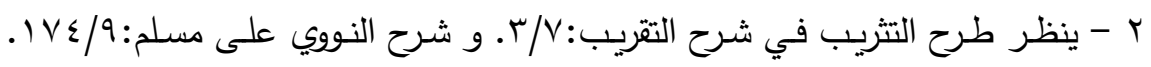

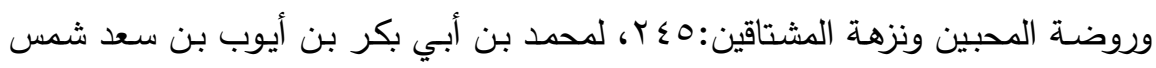

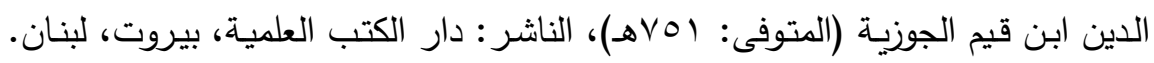


وسلم - والذي اشتمل على كثير من الألوان البلاغية والتي تآزرت جميعها في بيان فضل زواج الأبكار وكان منها:

- الحوار الذي دار بـين النبـي - صـلى الله عليـه وسـلم - وجـابر - -

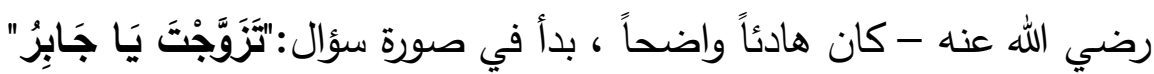
وتدرج حتى وصل لتقرير قضية اجتماعية مهمة ألا وهي الحث على زواج

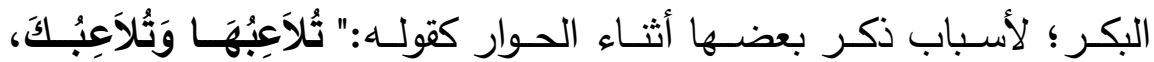

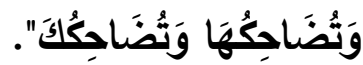
- الإيجاز بالحذف وهو سمة غالبة في هذا الحوار حيث يتطلبه المقام

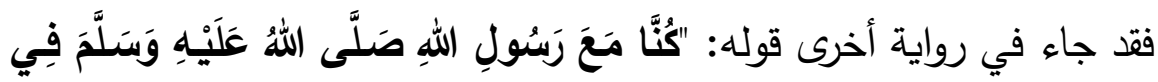

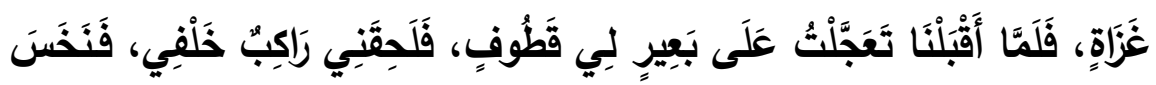

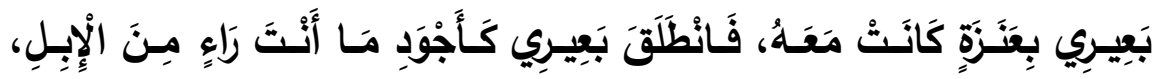

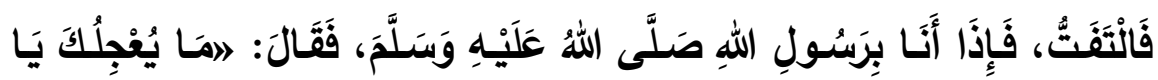

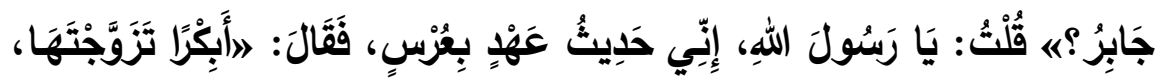

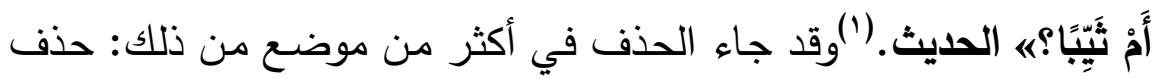
همزة الاستفهام في قوله: "تيَزَوَجْتَ يَا جَابِرُ"، وحذف المسند والمسند إليها من الجواب لدلالة السؤال عليه والتقدير : نعم تزوجت. وكذا حذف أداة الاستفهام

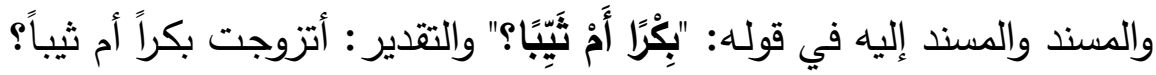
، وكذا حذف المسند والمسند إليه من الجواب: "بَلْ ثَيَّبا" والتقدير : بل تزوجت ثيباً، وذلك للمسارعة إلى بيان الوصف الذي هو الغرض من السؤال ألا وهو بيان صفة من تزوجها. كما أن في حذف الموصوف وإنابة الصفة محله

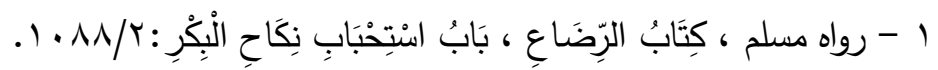

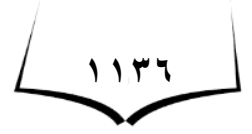


مسـارعة إلى بيـان مـا كـان ينبغي أن يكون مـن إيثار البكر على الثيب

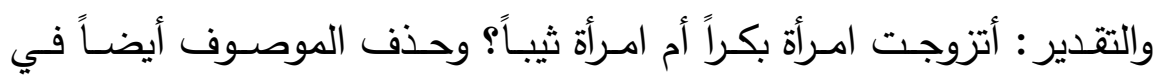
الجواب وتقديره: بل تزوجت امرأة ثيباً، وكذا حذف المسند والمسند إليه في

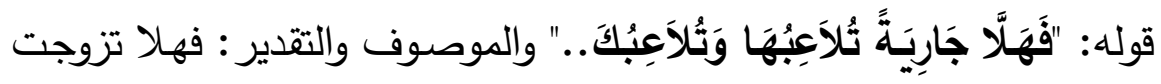
امرأة جارية.. وذلك للعلم به من السياق، وللحث على زواج البكر .

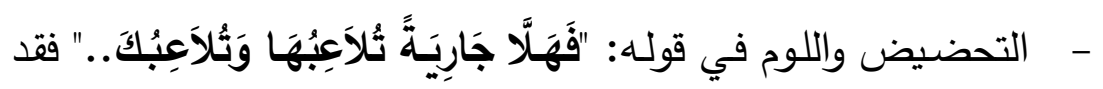
أراد بالجاريـة البكر، وذكر في الزواج من المرأة البكر معان: منها: حداثة السن، وللنفس في ذلك حظ وافر • ومنها: قوة الحرارة التي تحرك الباءة. ومنهـا: أن المـرأة يتعلق قلبهـا بـأول زوج، إذ لـ تعـرف سـواه، فيكون ودهــا منصرفا إليه. ومنها: أن كثيراً من الطباع تتبو عمن كان لها زوج.ومنها:

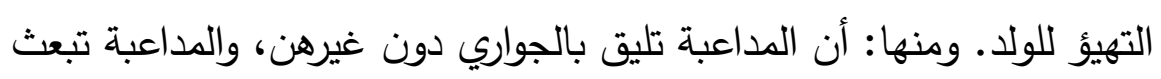
على اجتماع الماء وكثرته، إلى غير ذلك من الفوائد.(')

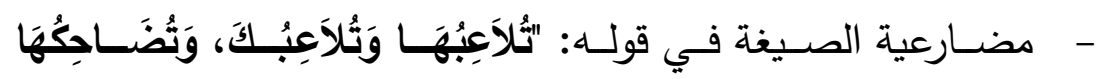
وَتُضَتساحِكُكَ" ومجيؤهـا على صـيغة التفاعل ممـا يـدل على مشــاركة الـزوج الزوجة في الفعل، والصيغة ترسم صورة متحركة للفعل وتصور وتجسد تلك ولك السعادة والألفـة الغـامرة التي تكون بين الزوجين والتي تفضسي إلى السكن

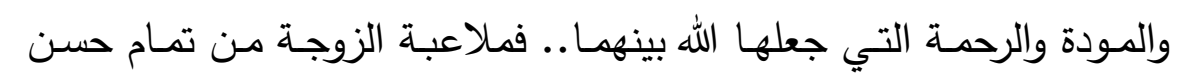

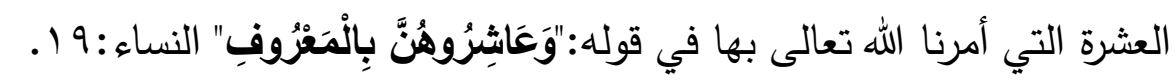
كما أن في ملاعبة الزوجة كف للنفس عن الحرام وإقناعها بالحلال.

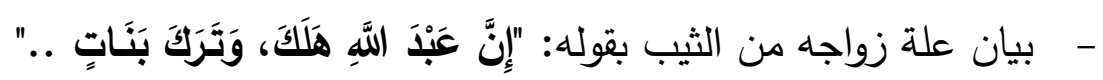
حيث جاء مؤكداً بأكثر من مؤكد لأن المقام يطلبه، فكأن النبي - صلى الله

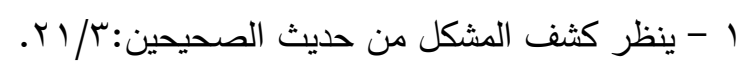


عليه وسلم - يطلب منه بيان علة زواجه هذا فحسن توكيده، حيث بيّن ذلك بوفاة أبيه فقد استشهد يوم أحد وترك كثيراً من البنات بيَّنهم في بداية الحديث بسـبع أو تسـع فـالتنكير فـي "بَتَـاتِ" للتكثيـر • وكـره أن يجمـع إلـيهن بكـراً مثلهن،لقلة خبرتها في شئون المنزل ولصنغر سنها، ولكنه تزوج ثيباً لتقوم عليهن وتمشطهن وتصـلح مـن شـأنهن ـ فدعا لـه النبي - صـلى الله عليـه وسلم- بالبركة لإيثاره إخوته على لذة نفسه وشهواتها.

\section{هق رواية الأسرة}

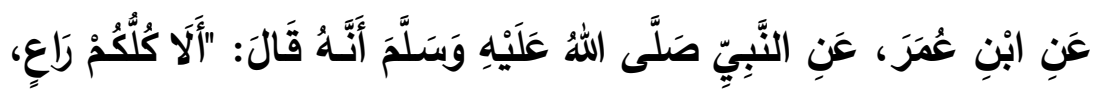

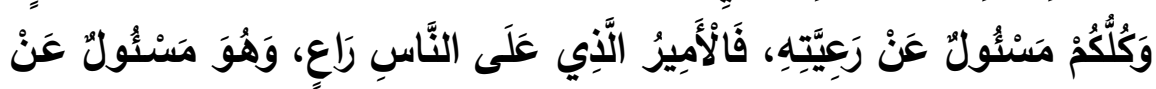

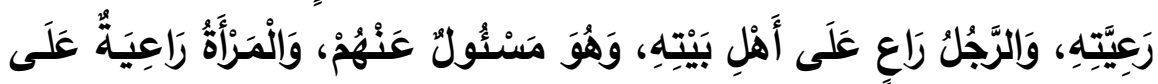

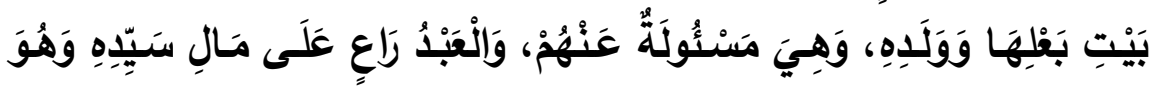

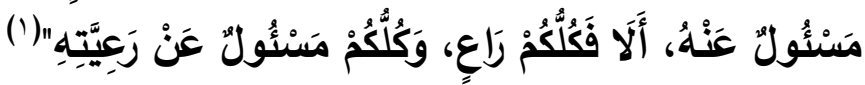
في هـذا الحـديث بـين لنـا النبـي - صــلى الله عليـه وسـلم - أن المسلمين جميعاً مكلفون بمهام عليهم أداؤها، لأنها تكاليف من رب العالمين وهي مختلفة تبعا لحال كل مكلف بَّءاً بالخليفة: الإمام الأعظم مرورا بالرجل في أهل بيته والمرأة في بيت زوجها وانتهاء بالخادم في مال سيده. فالمسئولية جماعيـة لا يخلــو منهـا أي إنسـان وذلـك تبعـا لدرجتهـه ومنزلتـه، وجـاءت المسئولية المشتركة عن البيت والأسـرة بعد مسئولية الإمـام، ولعلها مؤشر عليها، فالبيت والأسرة لبنة المجتمع، وإذا حسنت قيادة البيت وفق ما أمر الله ونهى حسنت قيادة المجتمع، فما هو إلا لبنات.. ويأتي التعميم والإجمال في

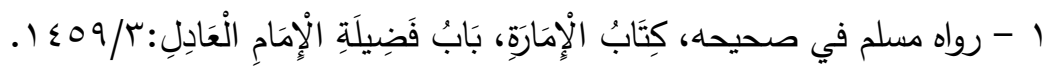

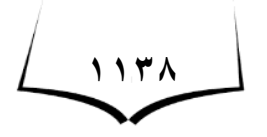


الحديث يعقبه التخصيص والتقصيل ثم التعميم والإجمال ليرد بالعجز على الصدر ليؤكد على تلك المسئولية ويبينها أجمل بيان. حيث ابتدأ الحديث بأداة التتبيه "أَلا" لينبه جميع المسئولين ويحضهم على القيام بالمسئولية الملقاة على عاتق جميع أفراد الأمـة، حيث لا يخلو

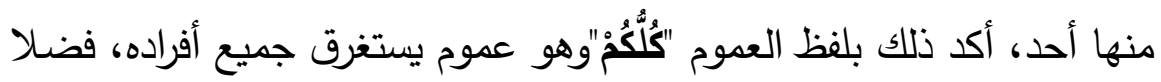
عن إضـافته إلى ضمير الجمع الذي يستغرق عموم المخاطبين، فهو عموم بعد عموم. وتنكير لفظ الرعاية والمسئولية " رَاعِ وَ مَسْئُولُه" في الحديث كله

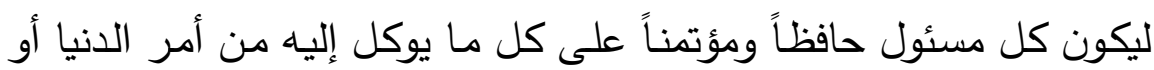
الدين، وليعلم أنه مسئول عمّا استرعاه الله حفظ أم ضيع.

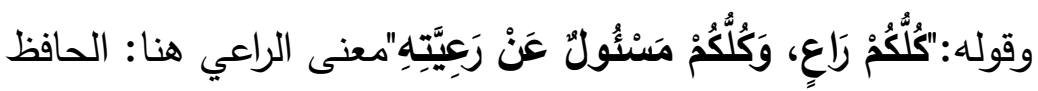
المؤتمن علي ما يليه، أمرهم النبي -صلى الله عليه وسلم - بالنصيحة فيما يلونه، وحذرهم الخيانة فيه بإخباره أنهم مسئولون عنـه، فالرعاية حفظ الثيء وحسن التعهد، وقد استوى من ورد ذكرهم في الاسم، ولكن معانيهم مختلفة، فرعاية الإمام ولاية أمور الرعية، والحياطة من ورائهم وإقامة الحدود والأحكام فيهم، ورعاية الرجل أهله القيام عليهم بالحق في النفقة وحسن العشرة، ورعاية المرأة في بيت زوجها، فحسن التدبير في أمر بيته والتعهد لخدمته وأضيافه، ورعاية الخادم، حفظ ما في يده في مال سيده والقيام بشغله. وفي قوله:"كُلَّكُمْ

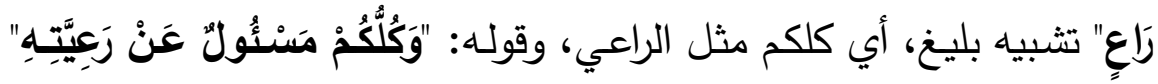
حال عمل فيه معنى التشبيه. وهذا مطرد في التفصيل، ووجه الثبيه حفظ الثسيء وحسن التعهد لمـا استحفظ، وتكرار لفظ العموم ليؤكد على شمول المسئولية لكل مكلف.وأفاد أن الراعي ليس بمطلوب لذاته، وإنما أقيم لحفظ مـا استرعاه المالك، فعلي السلطان حفظ الرعيـة فيما يتعين عليهه من حفظ مل 
شرائعهم، والذب عنها لكل متصد لإدخال داخلة فيها، أو تحريف لمعانيها، أو إهمال حدودهم، أو تضييع حقوقهم وترك حماية من جار عليهم ومجاهدة عدوهم، أو ترك سيرة العدل فيهم، فينبغي أن لا يتصرف في الرعية إلا بإذن الله ورسوله، ولا يطلب أجره إلا من الله كالراعي. ولذا يقول الإمام الطيبي -

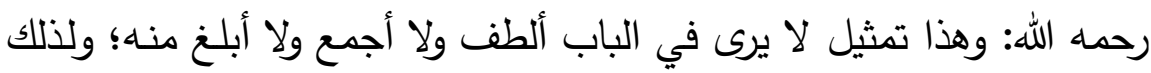
أجمل أولاً ثم فصله ثم أتى بحرف التتبيه مكرراً وبالفذلكة كالخاتمة. (') وجاء عطف الخاص على العام في الحديث للحثّ والحضّ على كَ ضرورة قيام جميع أفراد الأمة بمسئولياتهم الملقاة على كواهلهم، والتحذير من

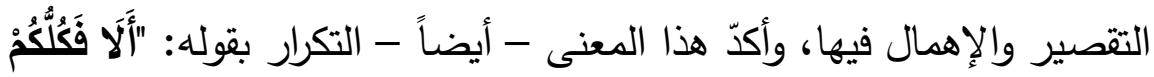

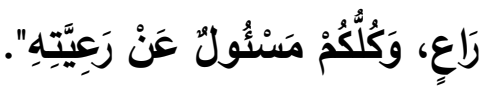
وإمعاناً في التخصيص بعد العموم يأتي التعريف بـ "أل" في ( الأمير والرجل والمرأة والعبد) وكذا الضمير المنفصل ( هو.. هي) والولاية متفاوتة

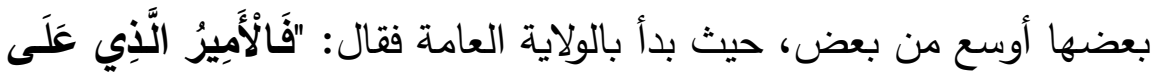

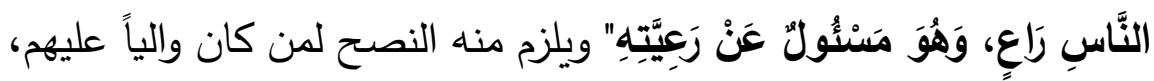
فيعمل على تحصيل كل خير لهم، ودفع كل شر عنهم، ويعمل على ما فيه صـلاح دينهم ودنياهم، وكل ذلك من واجباته. واتبع ذلك بالولايـة الخاصـة

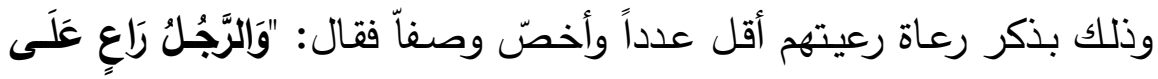

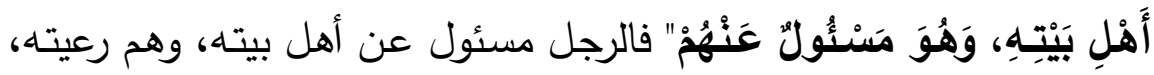
وهو مسئول عما استرعاه الله من أولاده ونسائه ومن يكون تحت ولايته في بيته، فيجب عليـه أن يعمل مـا فيـه خيرهم في ديـهم ودنيـاهم، بـأن ينفق 
عليهم، ويحسن إلـيهم، ويعـاملهم المعاملـة الطيبـة، ويعمل على اسـتقامة

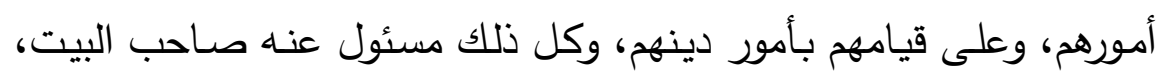

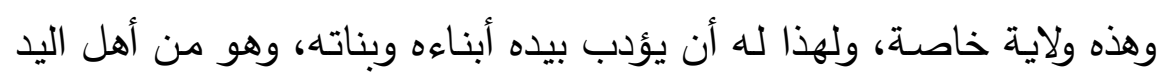
وأهل السلطة والولاية في ذلك، فهو راع ومسئول عن رعيته يوم القيامـة. ولم يجعل لهه هذا الأمر منفرداً بل جعل الزوجة شريكة لـه في ذلك ولذا أعقبه

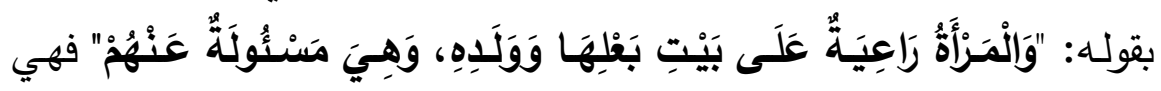
مسئولة عن قيامها بما هو واجب عليها في البيت من تدبير أمور البيت على لي الوجه المشروع، ومن رعاية الأولاد وتربيتهم وتتشئتهم، والإحسان إليهم، فهي مسئولة عن ذلك، ومسئولة عن رعيتها زوجها وبيته. وختم التصصيل ببيان

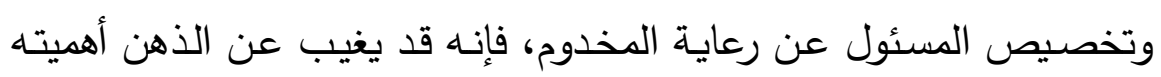

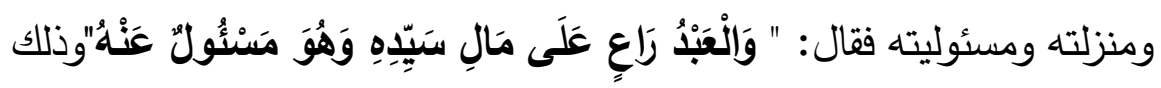
بحفظه فعليه القيام بما يستحقه عليه من حسن خدمته ونصحه، وهذا يوحي بعظم مهمته في حفظ مال المخدوم، وضـرورة المحافظة عليها، فإن خـان وغير وبدل فإنها يؤاخذ على ذلك يوم القيامة.

وختم الحديث بمـا بـدأ بـه؛ لأنـه بـدأ بـالتعميم، ثم فصّـل ثم ختم

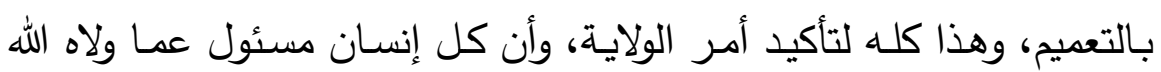
عليه، وما جعل إليه، وليس هذا مقصوراً على هذه الأصناف الأربعة، بل يعم كل من يكون مسئولاً عن شيء. وهذا الحديث يعد من جوامع كلمه صلى الله عليه وسلم - وجاء في صورة متدرجة،فقد حصل التدرج من الراعي برسم الإمارة وهو "الْأَمِيرُ " إلى الراعي برسم القوامة وهو "الرَّجُجُل" إلى الراعي

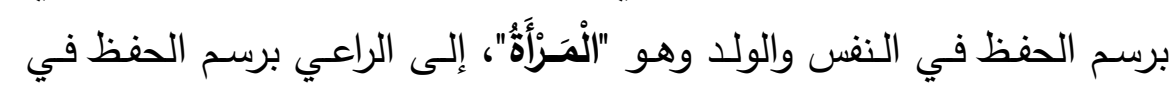

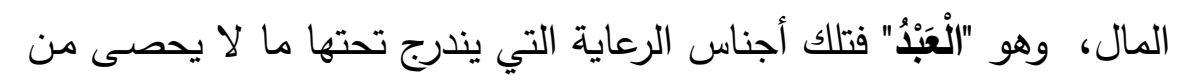


البلاغة النبوية فهي الحقوق الزوجية" "فيء الصحيحين"

الأقوال والأفعال برسم الإصلاح ، فجاء العموم ثم البيان فذكر تلك الأنواع

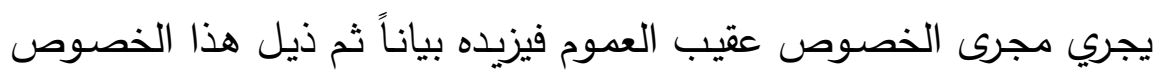

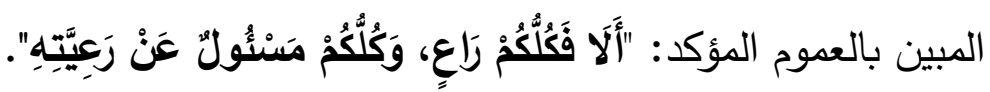




\section{الخـاتمهة}

الحمد الله الذي بنعمتهـ تتم الصـالحات، والصـلاة والسـلام على مـن

نزلت عليه أعظم الرسالات وعلى آله وصحبه وسلم ... وبعد:

فقد عشتُ في رحاب البلاغة النبوية، أنهل من معينها الفياض، وأسبح في بحرها الزاخر -قدر استطاعتي - أتأمل وأتدبر أحاديثه الزوجية في الصحيحين ، ولحظت أنها تحوى كثيراً من الخصائص واللطائف

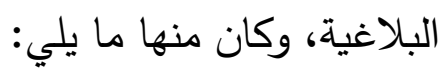

ا - تميزت الأحاديث عن الحقوق الزوجيـة في الصـحيحين بالإيجاز ، فجاءت موجزة قويـة السبك معبرة عن المعنى. وكان الأسلوب الخبري فيها هو الغالب لأنه الأنسب لمقام التعليم والنصح والإرشاد. ץ- حث البيان النبوي على الوصية بالنساء، إمـا بالأمر الصريح بذلك وإما بالترغيب في الزوجة، ومرة بالتماس العذر لها في سوء معاملاتها، وفي كفرانها العشير ، ومـرة بالحث على الصـبر على اعوجاجها للحاجـة إليها، وبالإحسان إليها.

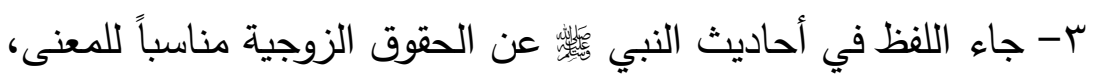
ملائماً للغرض المسوق له، وعمل على رسم صورة نابضـة متحركة، تختلف اهف باختلاف الأحوال رغبة ورهبة، وجاء موحياً معبراً عن المعنى الذي جيء لأجله.

ع- راعى البيان النبوي حالة المرأة النفسية وحاجاتها الاجتماعية وما قد يترتب عل إهمال ذلك من الفساد والانحراف، فبين ما لها من حقوق حتى وهي في أشد حالات ضعفها. 
هـاء الحوار في أحاديثه عن الحقوق الزوجية هادئاً واضحاً موجزاً،

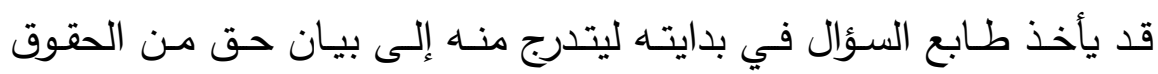
الزوجية أو تقرير قضية اجتماعية.

7- اتسمت أحاديث الحقوق الزوجية بالسهولة واليسر والوضوح والبعد البهد عن الزخـارف اللفظية؛ لأن غايتها التعليم والنصـح والإرشـاد، فمقامها مقام عظمة وعبرة ، ولا يحتاج إلى تحسين الكلام بقدر ما يحتاج إلى التأكيد على لإلى المعنى المراد. وهذه سمة الأسلوب النبوي التعليمي الذي يؤثر الوضوح على لي الغموض، ويستخدم الأسلوب المهذب البعيد عن الزينة والزخرفة إلا ما تطلبه المقام وجاء عفو الخاطر . المعاء - V كان لأسلوب الحوار النبوي في أحاديث الحقوق الزوجية الأثر البالغ في جذب الانتباه وإقرار حقائق وقضايا اجتماعية مهمة وذلك بأسلوب تسكن باه النفوس؛ لما فيه من الإقناع والرحمة واللطف في الخطاب. 1- جاءت الكناية عن الحقوق الزوجية متأثرة بالكنايات في القرآن الكريم في أسلوبها وطريقتها ومقامها، وألفاظها وحسن تصويرها وقوة تأثيرها.فالسنة

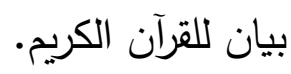
9- كان للتأكيد بأساليبه المختلفة، وطرقه المتعددة دور مهم في التأكيد على حقوق كل مـن الزوجين ممـا سـاعد على سـرعة الالتزام بها والعمـل بمقتضاها.

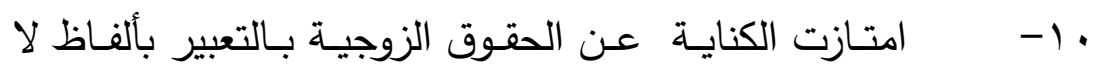
تخدش الحياء، فيها معنى العفة وهجر الفحش من القول، وتهذيب لا تتفر

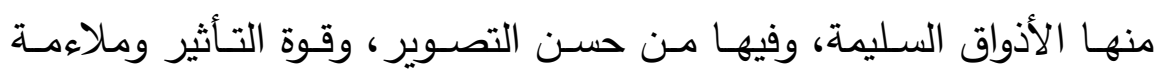
معانيها التي جيئت لأجلها. 
11 - آزرت الألوان البلاغية في بيان الحقوق الزوجية، وجاءت في صورة بديعة، مطابقة لمقتضى الحال والمقام، كاشفة النقاب عما لكل من الزوجين من حقوق وما عليه من واجبات

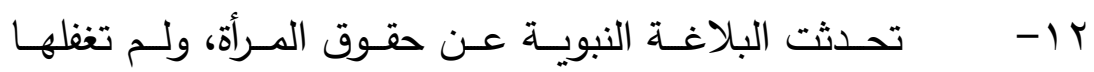
وصورتها أجمل تصـوير ، وبينت فطرتها وكيفية التعامل معها وأناطت بها مسؤولية البيت والعمل التربوي الكبير •

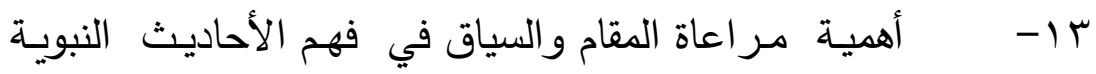
الخاصـة بالنسـاء حتى تحمل على وجهها الصـحيح، من بيان علو مكانة المرأة في الإسـلام. وحتى لا يؤدي فهمها على غير مرادها إلى نتائج تضر

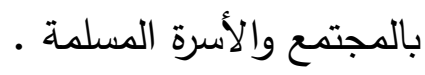
ع ا- - ق قلَّت صور المجاز في أحاديث الحقوق الزوجية ؛ ولعل ذلك

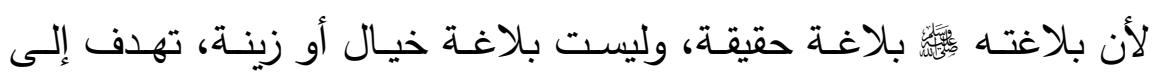
تمكين حقائق معينـة في النفوس والقلوب والعقول، سـاعية إلى إقرار منهج للحياة وتقويم سلوك الأفراد والأسرة والمجتمع. وبعد ... فهذا هو جهد المقلّ، فإن كنت قد وفقت فلله الفضل والمنـة، وإن كان غير ذلك فاله أسأل المغفرة على تقصيري، والسداد والتوفيق في عملي، إنه نعم المولى ونعم النصير •

وصلى الله على سيدنا تحمد وعلى آله وصحبه وسلم.

प 


\section{فهرس الصادر والمراجع}

$$
\text { القرآن الكريم. }
$$

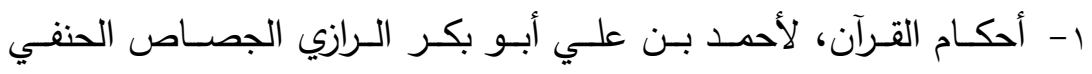

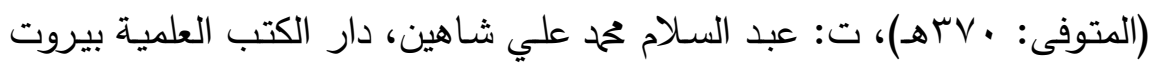

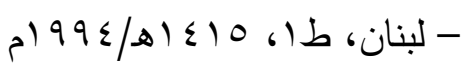

r- إرشاد الساري لشرح صحيح البخاري .لأحمد بن حمحد بن أبى بكر بن عبد الملك القسطلاني القتيبي المصري، أبو العباس، شهاب الدين (المتوفى: بrوهـ)،

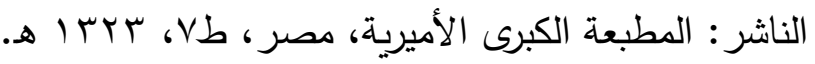

r- أضـواء البيان في إيضـاح القرآن بالقرآن، لمحمد الأمين بن محمد المختار بـن عبد القـادر الجكنـي الثـنقيطي (المتوفى : بوساءهـ)، الناشـر : دار الفكر

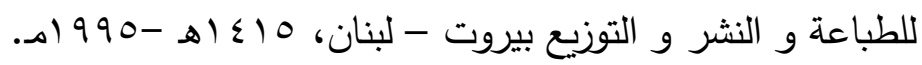
ع - الإفصـاح عـن معـاني الصـحاح، ليحيـى بـن (هُبَيْرَة بـن) عحمد بـن هبيـرة

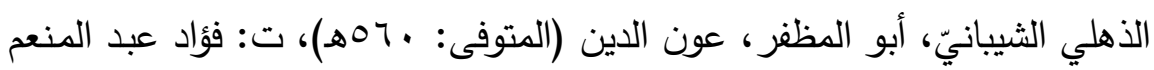

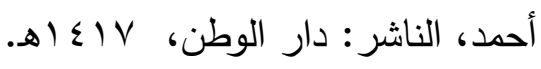
ه- بدائع الصنائع في ترتيب الثرائع، لعلاء الدين، أبو بكر بن مسعود بن الهن

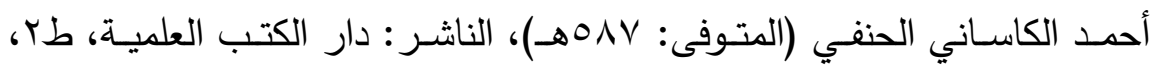
م) $9 \wedge 7-81 \leq \cdot 7$

7- البرهان في وجوه البيان لابن وهب، ت. د/ حفني ححم شرف، نشر / مكتبة

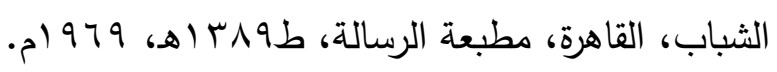

v- بهجة قلوب الأبرار وقرة عيون الأخيار في شرح جوامع الأخبار ، المؤلف:

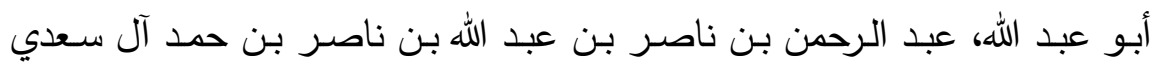

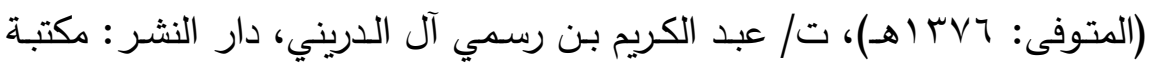

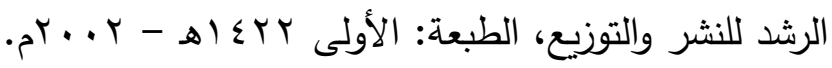




\section{مجلة قطاع كليات اللفة العربية والشعب المناظرة لها العكد [r]]}

^- تحريـر المـرأة في عصـر الرسـالة ، عبـد الحلـيم أبـو شـقة ، دار القلـم،

$$
\text { الكويت، القاهرة، طه، } 1999 \text { 19 م. }
$$

9- حقوق المرأة في ضوء السنة النبوية ، نوال بنت عبد العزيز العيد، طا،

$$
\text { . } r \text { r } r-1 \leq r v
$$

1 - الخصـائص، لأبسي الفتح عثمـان بـن جني، الناشـر : عـالم الكتب -

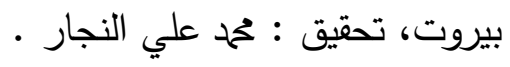

| 1 - دراسـات أدبيـة ولغويـة من الحديث الثـريف، حمح علي الصـابوني،مكتبة

$$
\text { الأقصى، مكة المكرمة، • لو ام. }
$$

با - دلالات التراكيب دراسـة بلاغيـة ، د/ محمد محمد أبو موسـى، مكتبـة وهبـه،

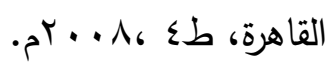

rا - دلائل الإعجاز ، للإمـام عبد القاهر الجرجاني ، ت/محمود محمد شاكر ،

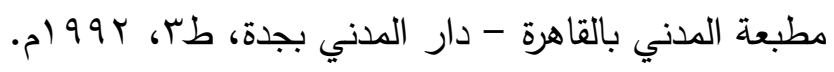

ع ا - دليـل الفـالحين لطـرق ريـاض الصـالحين، لمحمـــــن عـلان الصــيقي

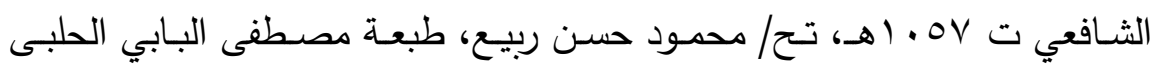

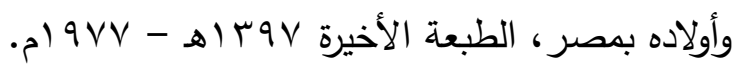

1 - سنن أبي داود ، لأبي داود سليمان بن الأشعث بن إسحاق بن بشير بن

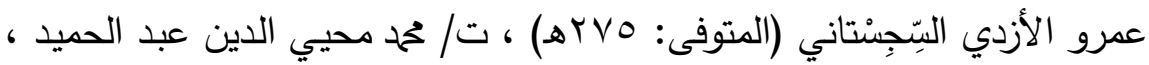

$$
\text { المكتبة العصرية، صيدا - بيروت. }
$$

17

النسائي (ت: ץ • rهـ)، ت: حسن عبد المنعم شلبي ،الناشر : مؤسسـة الرسـالة -

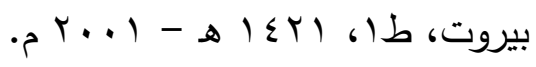


V ا - شرح الرضسي على الكافية، لرضسي الدين الأستراباذي، تصحيح وتعليق:

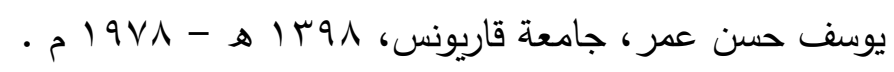

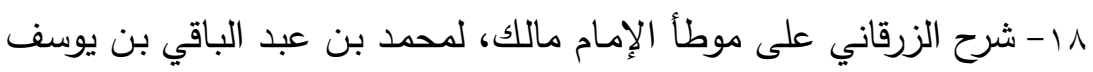

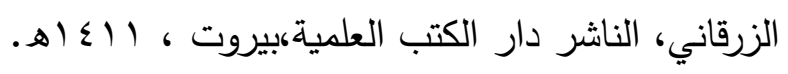

9 1 - شرح الطيبي على مشكاة المصـابيح المسـى بـ (الكاشف عن حقائق

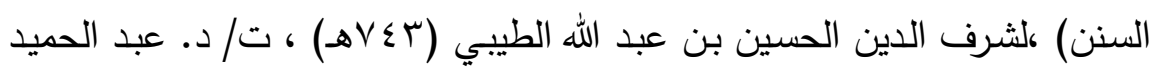

$$
\text { هنداوي ، مكتبة نزار مصطفى الباز (مكة المكرمة - الرياض). }
$$

•r- شرح النووي على صحيح مسلم ، المسمى: المنهاج شرح صحيح مسلم بن الحجـاج، لأبي زكريـا يحيى بن شرف بـن مري النووي، الناشـر : دار إحياء

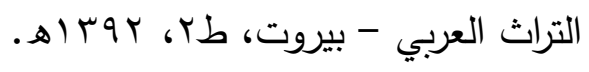

اب - شرح حديث جابر بن عبد الله رضسي الله عنهما في صففة حجة النبي

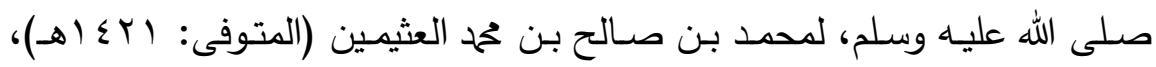

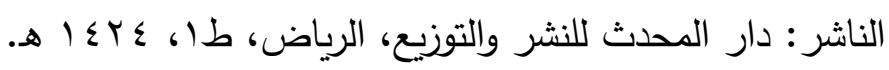
r - شرح سنن النسائي المسمى ذخيرة العقبى في شرح المجتبى، لمحمد بن

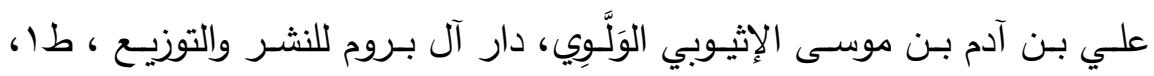

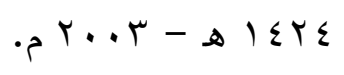

rr- شرح صحيح البخاري لابن بطال، لابن بطال أبو الحسن علي بن خلف

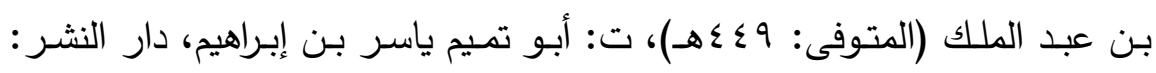

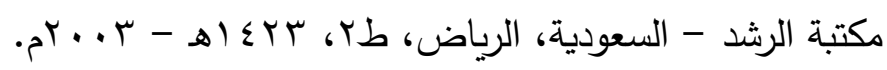

ع - صحيح مسلم، للإمام مسلم بن الحجاج أبو الحسين القشيري النيسابورى

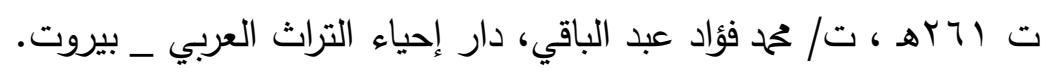




\section{مجلة قطاع كليات اللفة العربية والشعب المناظرة لها العكد [r]]}

هץ- طرح التريب في شرح التقريب ،لأبي الفضل زين الدين عبد الرحيم بن الحسين بن عبد الرحمن بـن أبي بكر بـن إبراهيم العراقي (المتوفى: 7 ــهــ)، الناشر : دار إحياء التراث العربي.

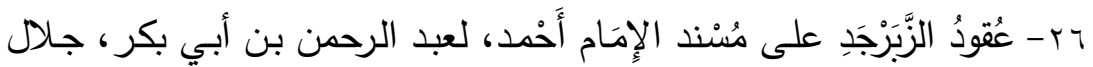

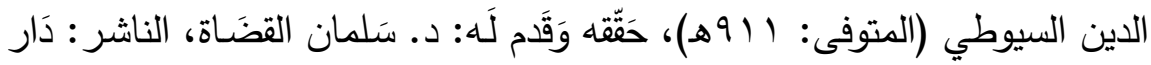

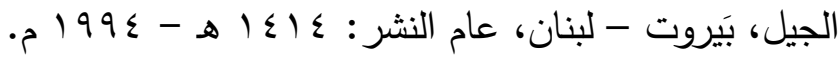

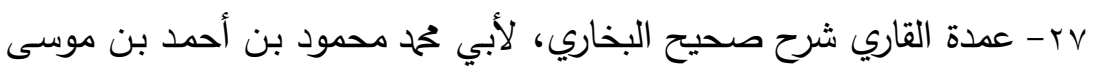
بن أحمد بن حسين الغيتابي الحنفي بدر الدين العيني (المتوفى: 100هــ) ،الناشر :

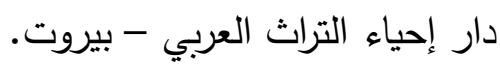

^ץ- روضة المحبين ونزهة المشتاقين، لمحمد بن أبي بكر بن أيوب بن سعد

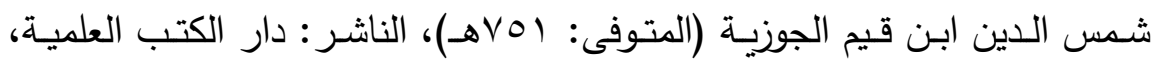

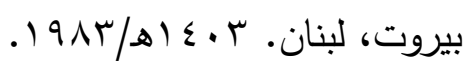

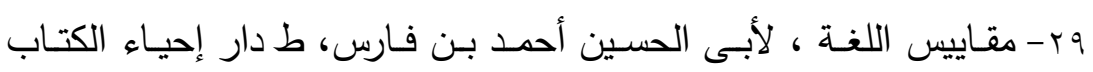

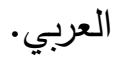

• r- الصحاح ، لإسماعيل بن حماد الجوهري، تح/أحمد عبد الغفور، القاهرة، .01914

اب- تهذيب الأخلاق، لابن مسكويه، ط دار الكتب العلمية، بيروت.

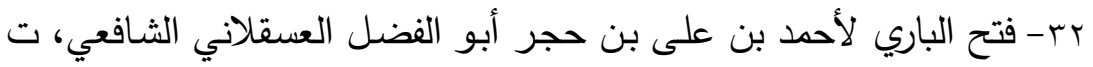

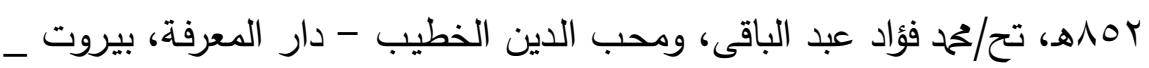

rr- فتح ذي الجـلال والإكرام بشرح بلوغ المرام، لمحمد بن صـالح العثيمين،

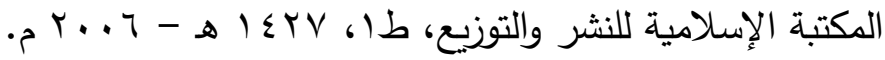
§؟ب- فتح المنعم شرح صحيح مسلم، للدكتور / موسى شاهين لاشين، الناشر :

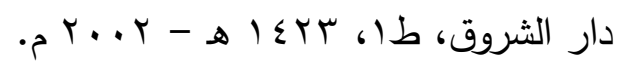


هr- الفروق اللغويـة، لأبي هـلال الحسن بن عبد الله بن سهل بن سعيد بن يحيى بن مهران العسكري (المتوفى: نحو ه9 هـ)، ت: محمد إبراهيم سليم، الناشر : دار العلم والثقافة للنشر والتوزيع، القاهرة - مصر. بr- فيض الباري على صحيح البخاري، المؤلف: (أمالي) حمح أنور شاه بن

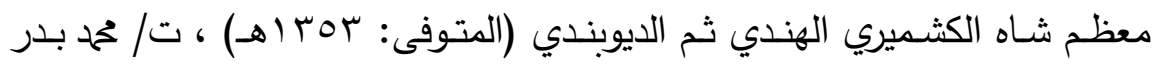

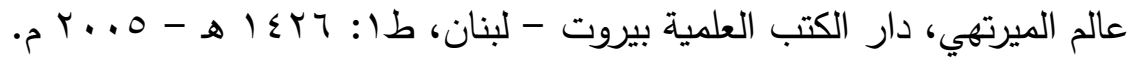

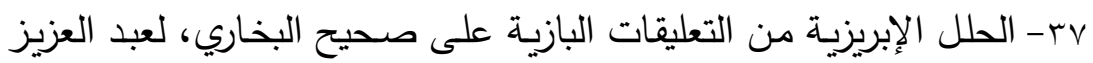

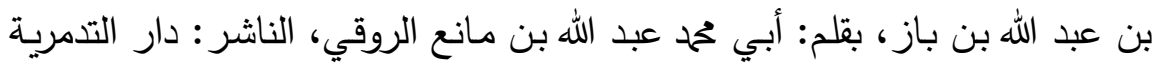

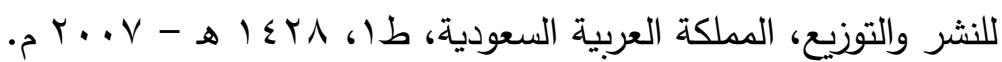
^r- فقه الإسلام 》اشرح بلوغ المرام من جمع أدلة الأحكامه، لعبد القادر شيبة

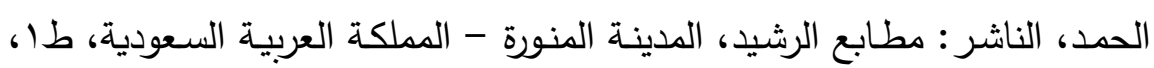

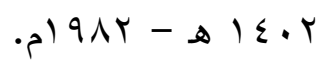

qr- فيض القدير شرح الجامع الصغير ، لزين الدين تحمد المدعو بعبد الرؤوف بن تاج العارفين بن علي بن زين العابدين الحدادي ثم المناوي القاهري (المتوفى:

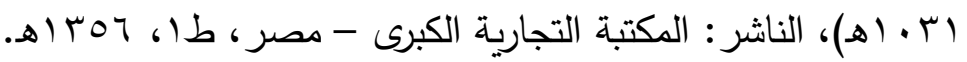

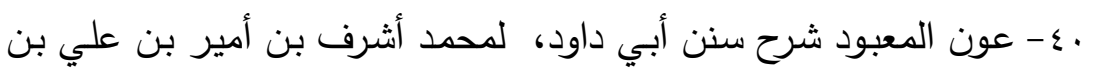

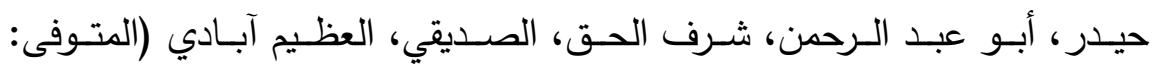

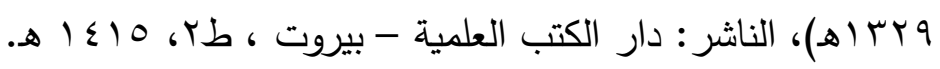

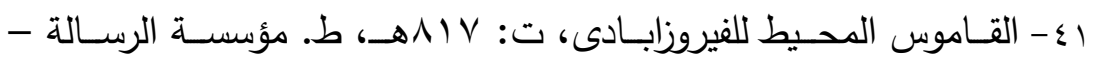

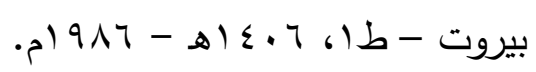

rع - الكثاف عن حقائق غوامض التنزيل، لأبي القاسم محمود بن عمرو بن

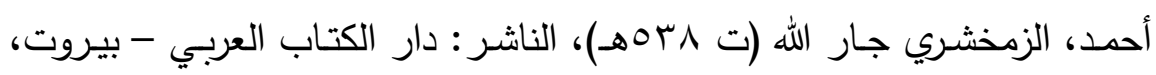

$$
\text { طس - اله }
$$


بـ - كثف المشكل مـن حديث الصـحيحين، لأبسي الفرج عبد الرحمن ابـن

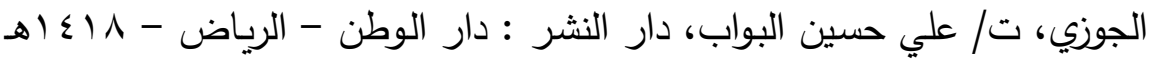
. $99 \mathrm{~V}-$ § - الكواكب الدراري في شرح صحيح البخاري، لمحمد بن يوسف بن علي

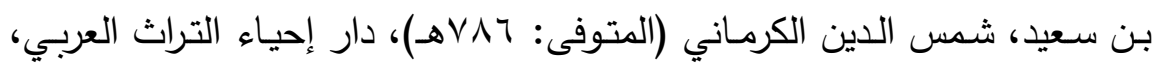

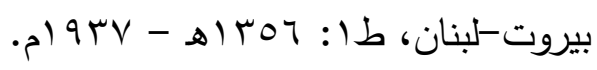
هـ - الكوكب الوهَّاج والَّرَوض البَهَّاج في شرح صحيح مسلم بن الحجاج، جمع

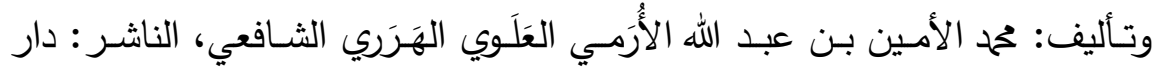

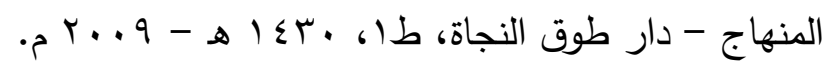

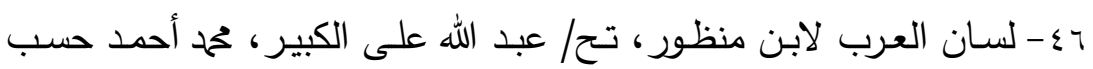
الله، هاشم ححم الثاذلى، ط. دار المعارف بالقاهرة.

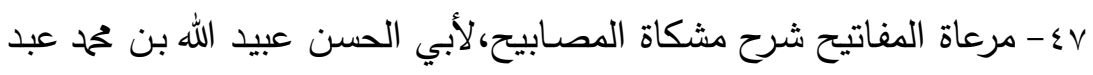
السلام بن خان ححمد بن أمان الله بن حسام الدين الرحماني المباركفوري (المتوفى ع إ (هـ) ، الناشر : إدارة البحوث العلمية والدعوة والإفتاء - الجامعـة السلفية -

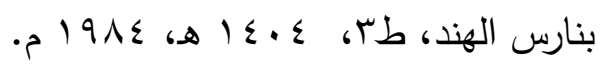

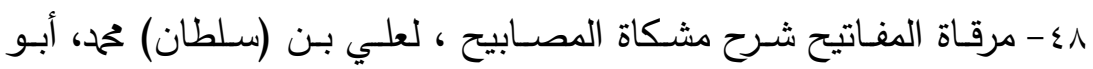
الحسن نور الدين الملا الهروي القاري (ت ع ا ـ (هـ) ، دار الفكر، بيروت - لبنان

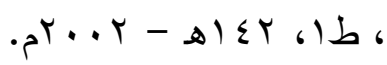

9 - مسند الإمام أحمد بن حنبل، المؤلف: أبو عبد الله أحمد بن محمد بن حنبل

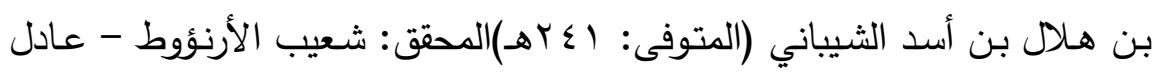

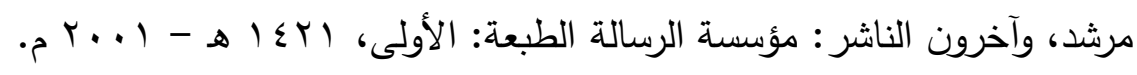

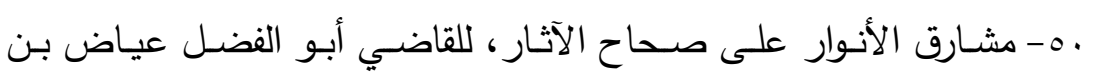
موسى بن عياض اليحصبي السبتي المـالكي، دار النشر : المكتبة العتيقة ودار

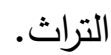


اهـ - المفاتيح في شـرح المصـابيح، للحسين بـن محمود بـن الحسن، مظهر

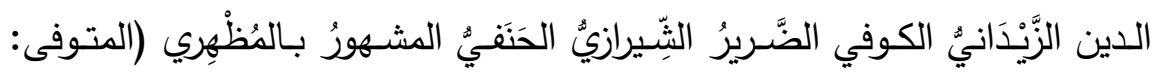

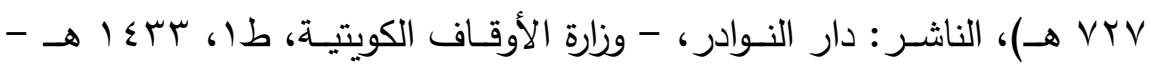
. $r \cdot 1 r$

ro - المفردات فى غريب القرآن للراغب الأصفهانى، تح/ ححمد سيد كيلانى، ط. دار المعرفة - بيروت لبنان.

rه - المفهم لما أشكل من تلخيص كتاب مسلم، لأبي العباس أحمد بن عمر برن بن إبراهيم القرطبي (OVA - 107 هـ)، حققه وعلق عليه وقدم لـه: محيي الدين ديب ميستو - أحمد محمد السيد - يوسف علي بـديوي - محمـود إبـراهيم بـزال،

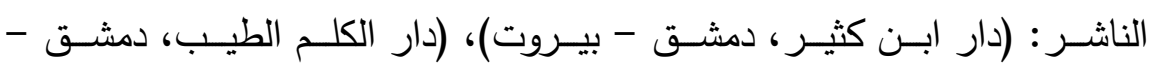

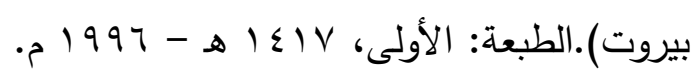
ـه- منـار القاري شـرح مختصـر صـحيح البخاري، لحمزة محمد قاسم، راجعه:

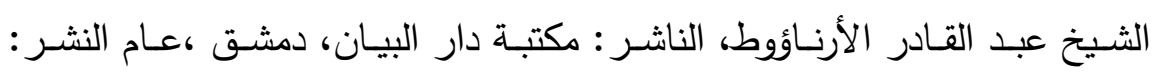

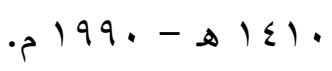
هـ - المنهـل الحديث في شـرح الحـديث، للـدكتور / موسـى شـاهين لاشـين،

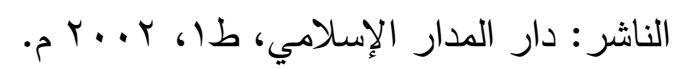

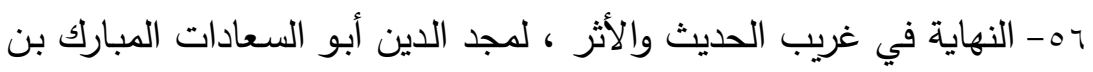
ححم بن ححمد بن ححم ابن عبد الكريم الثيباني الجزري ابن الأثير (المتوفى: 7 ـ بـهـ)

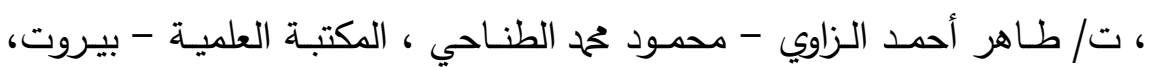




\section{مجلة قطاع كليات اللفة العريبية والشعب المناظرة لها العكذ[ب]}

فهرس الموضوعات

\begin{tabular}{|c|c|}
\hline الموضوع الموع & b \\
\hline 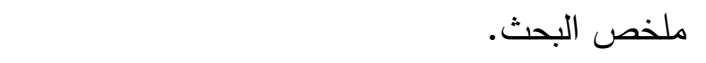 & -1 \\
\hline 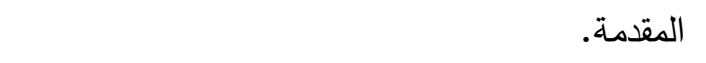 & $-r$ \\
\hline المبحث الأول: حقوق الزوج على زوجته. & $-r$ \\
\hline حق التأديب. & $-\varepsilon$ \\
\hline لا تأذن في بيته إلا بإذنه. & -0 \\
\hline شكر نعته عليها. & -7 \\
\hline 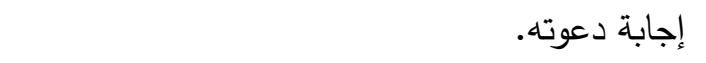 & $-V$ \\
\hline الاستمتاع بها حال حيضها. & $-\wedge$ \\
\hline طاعته في غير معصية. & -9 \\
\hline المبحث الثاني: حق الزوجة على زوجها. & -1 \\
\hline حسن المعاشرة. & -11 \\
\hline مرافقة زوجها لها في الحج. & -14 \\
\hline المعاملة الطيبة وبيان فطرتها. & -14 \\
\hline التغاضي عن بعض ما يكون منها. & $-1 \varepsilon$ \\
\hline 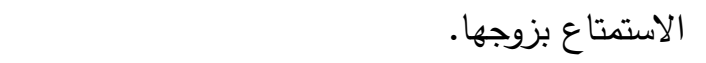 & -10 \\
\hline الحق في النفقة. & -17 \\
\hline الاختصاص بأيام عند الزواج. & $-1 \mathrm{~V}$ \\
\hline حق الزوجة في إبلاغها بوقت قدوم الزوج بعد غياب. & -11 \\
\hline حق الزوجة في الخلع. & -19 \\
\hline المبحث الثالث: حقوق الزوجين المشتركة. & $-r$. \\
\hline حفظ السر • & $-r_{1}$ \\
\hline الوفاء بالشروط . & $-Y r$ \\
\hline الاستمتاع. & $-r r$ \\
\hline حق رعاية الأسرة. & $-Y \varepsilon$ \\
\hline
\end{tabular}

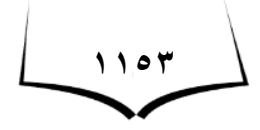


الجلإة النبوية فهي الحقوق الزوجية "فهي الصحيحين "

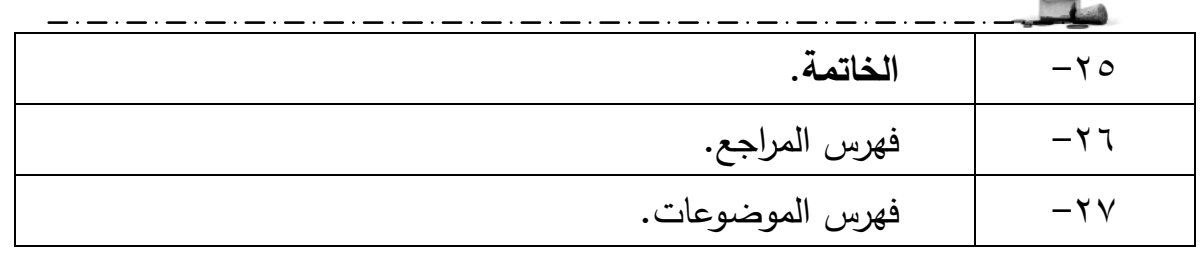

